\title{
at ||$|3|$
}

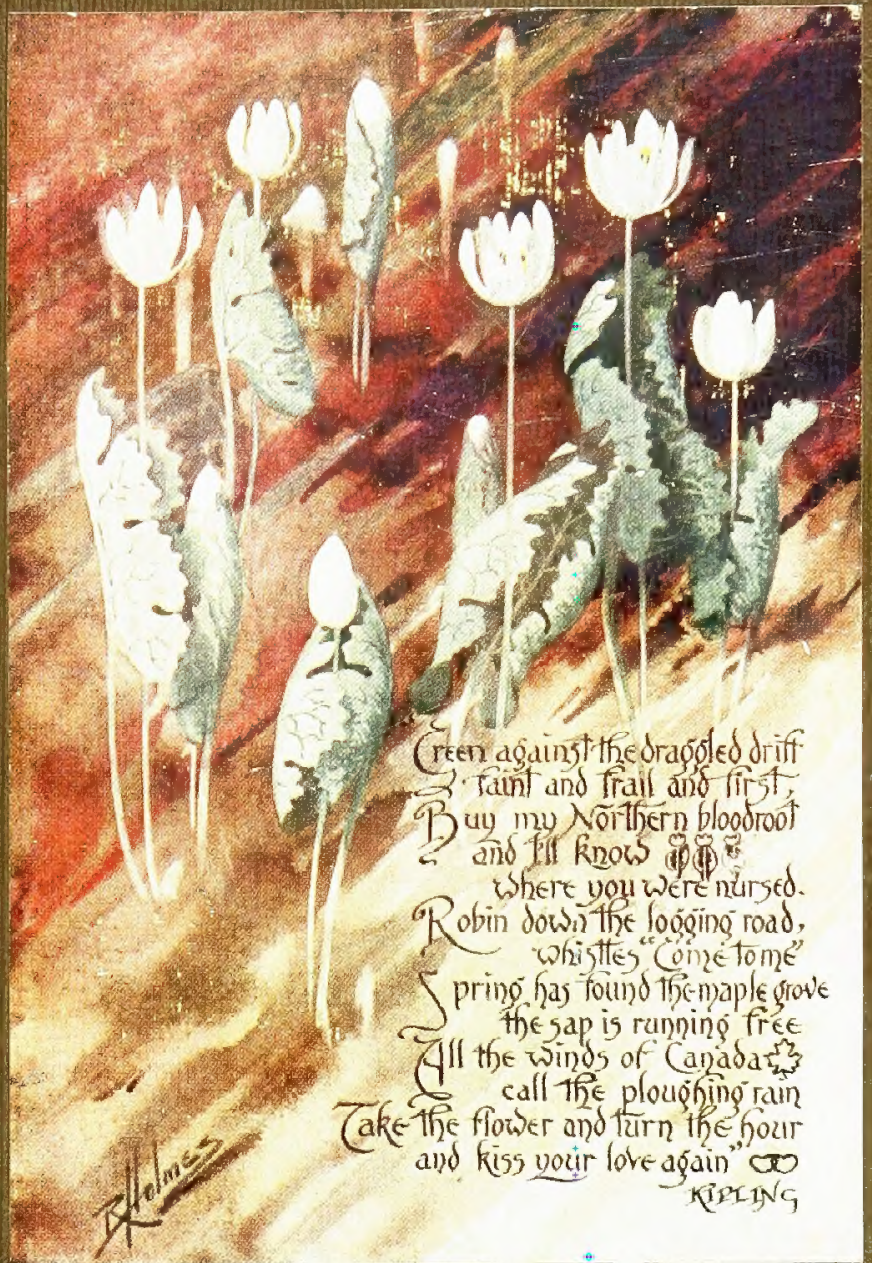

8. T. TVOOD 


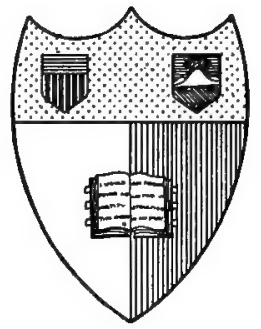

\section{Gartell \#ntueraity Wibrary}

Itḩaca, Aru hack

BOUGHT WITH THE INCOME OF THE

SAGE ENDOWMENT FUND

THE GIFT OF

HENRY W. SAGE

1891 


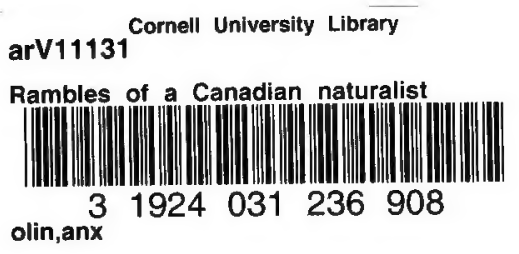




\section{Cornell University Library}

The original of this book is in the Cornell University Library.

There are no known copyright restrictions in the United States on the use of the text. 


\section{RAMBLES OF A CANADIAN NATURALIST}






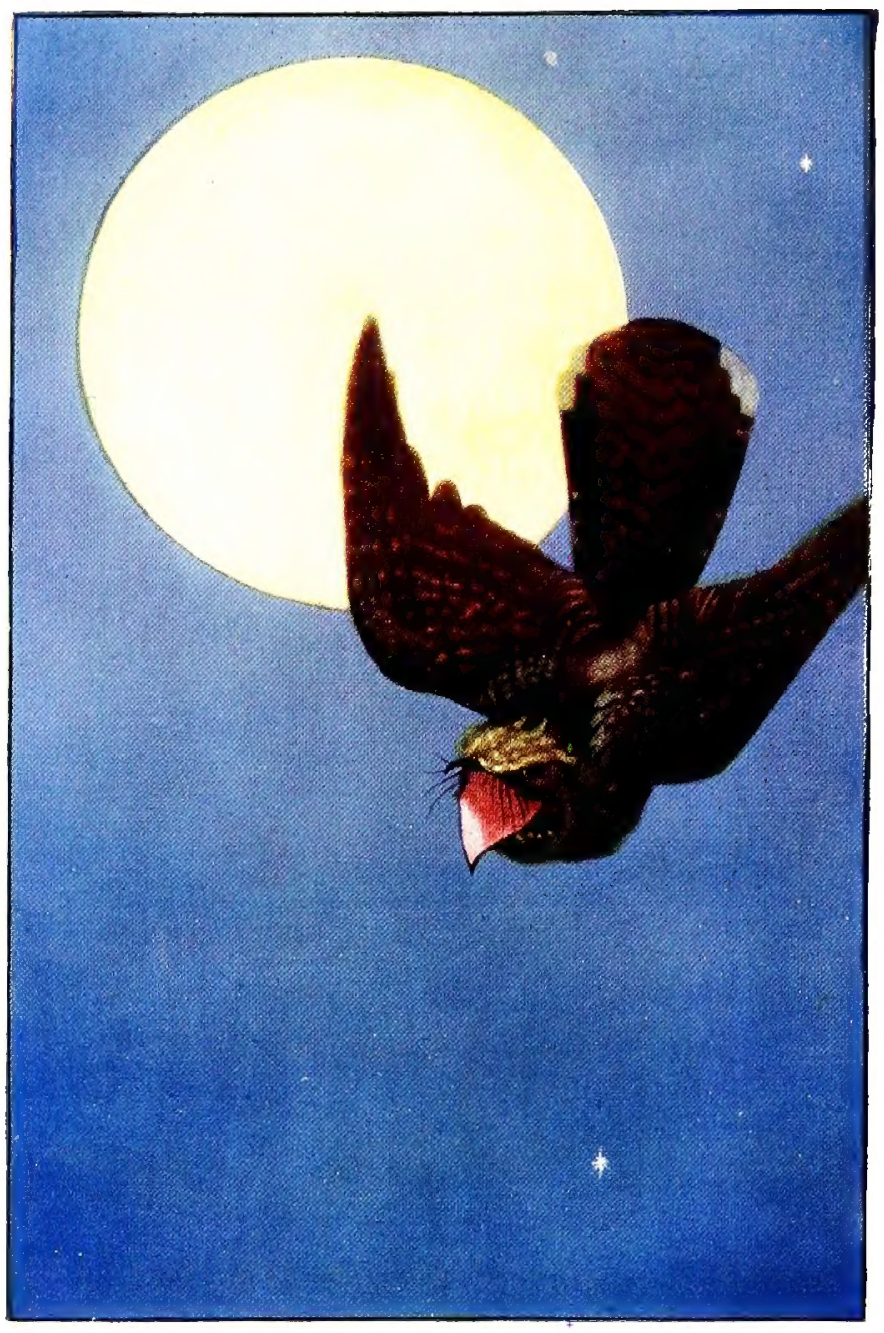

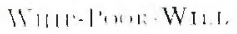




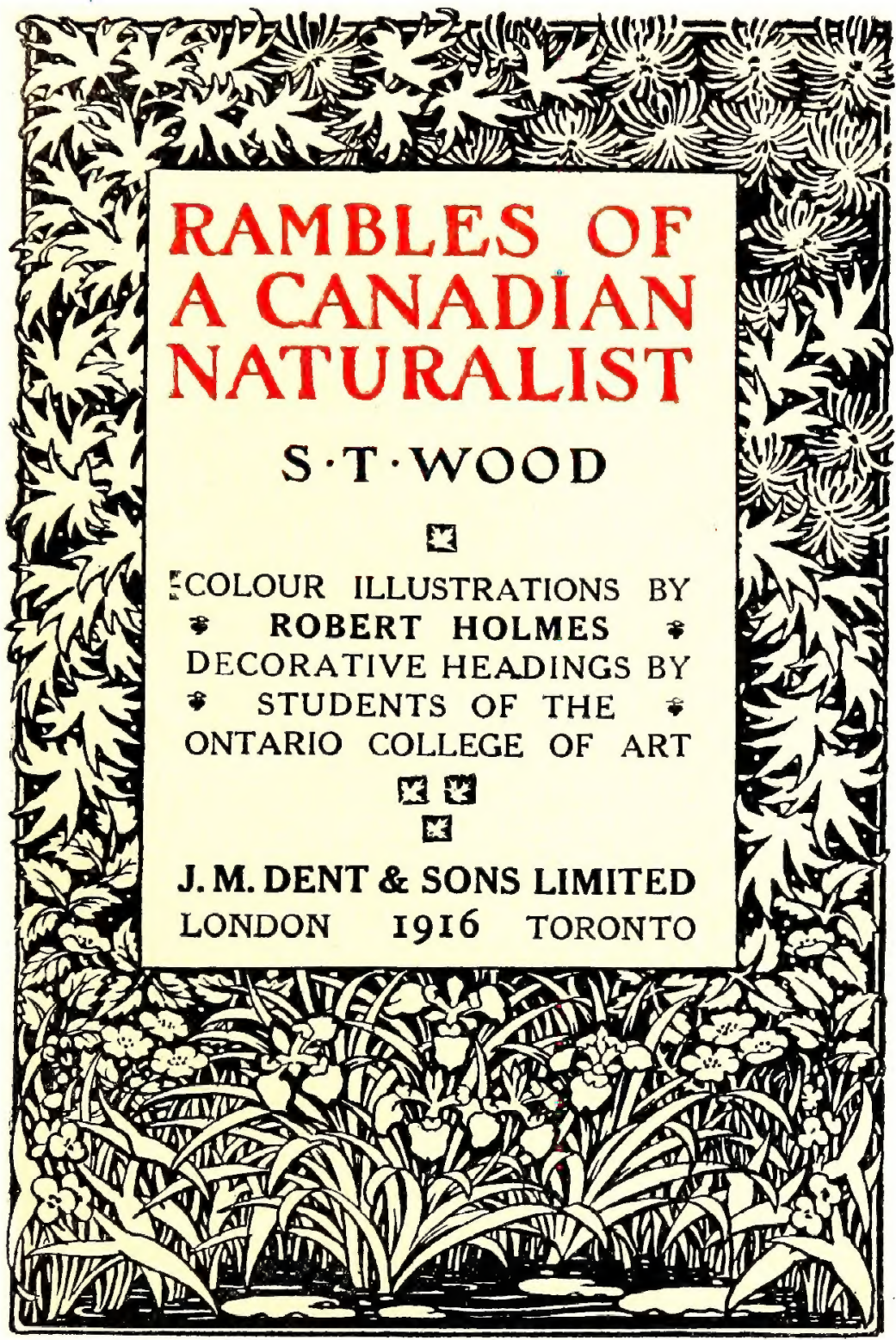





\section{CONTENTS}

AN OPENING WORD

PAGE

$\cdot \quad \cdot \quad \cdot \quad \cdot \quad I$

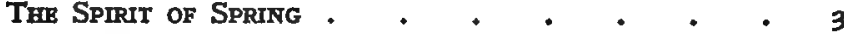

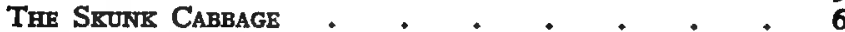

The Pitcher Plant + * * . . * . 8

Birds of THE SEason * * + * * * * II

UNAPPRECIATED FloWERS . • • • • • 14

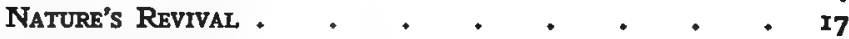

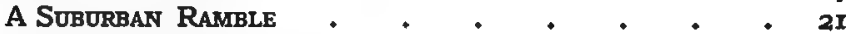

Dimivutive Beavers . * • • • . • 25

The American Mergansers + . . . . . 28

The AWAKENING Year • . . . . . . . $3 I$

The Voice of the SILENCE . • • • • • 34

THE BlOOD-ROOT . . . . . . . . 37

"YA HONK! YA HONK! Y Y HONK!" . . . . 39

SUDDEN SUMMER + + + . . . . . 42

A SoNg of THE Night . . + . + . + 45

AN INDOLENT RIVER . . . . . . . . 48

A SEAson OF GRowth . . + . + . . 52

As THE YeAR Grows . . . . . . . 55

The Dandelion . • . . . . . . 59

A SUMMER RESIDENT • • • • * . . 62

THE NIGHT-HAWT . + . + . + . + 65

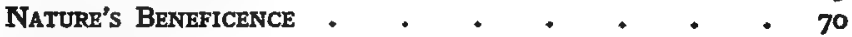

DON'T PLUCK IT . . . . . . . • 73

A RECORD OF TIME • • • • • • • • 77

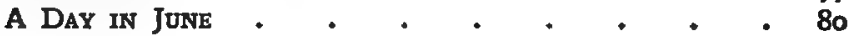

Melodrama aNd Tragedy . . . . . . 84

An Unfortunate Mourning Dove $\quad . \quad \cdot \quad 8_{7}$

The Life of a Moth . . . . . . . 90

Popular Tyrants

SPOTTED SANDPIPERS + • • • • • 98

IN A SUlTRY SWAMP . + . . . . . IOI

A Successful Pretender . . . . . . . 105

Below Niagara . • . + . . . . . 109

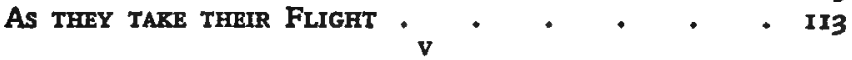


The Graat NorthitrN Diver. Tere Powder Post Beetre

A Froating IsLaNd Active Gleaners . Flocking Already! WhEN THE Swallows The Fascination of LIGHT. The Canadian Mocking-Bird The Old Sport

A Migrating Butterfly The Great Blue HeroN Flowers OF THE SEASON The Passing of Summer The Waning Year THE WITCH HAZEL TrEe Tussock Moth EPIPACTIS VIRIDIFLORA Departing SumMer Visitors WHIP-POOR-WILL Birds of Passage . The Haunt of the Coot A LONELY WANDERER The Autuma Panorama The Dead Leaves fall WeATHER PROPHETS As the Year Passes Preparing for Spring EARLY WINTER SOME WINTER VIsITORS . WINTER BUDS BITTERSWEET . IFSPIRED BY THE SNOW . An Evening Revellek The Great Horned OWL MUSKRats LAST DAY OF DANGER THE Beach IN Winter Nature's Dreams . INDEX 


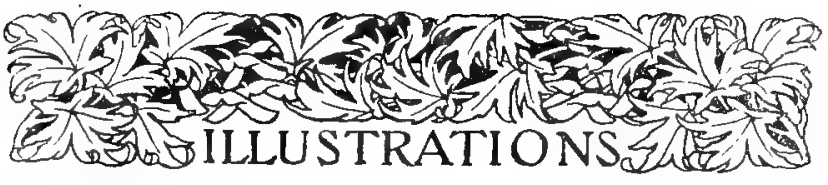

\begin{tabular}{|c|c|c|c|c|c|c|c|c|}
\hline WHIP-POOR-WILL & + & • & • & & • & • & \multicolumn{2}{|c|}{ Frontispiece } \\
\hline BLOODROOT & - & • & • & * & • & • & Facing page & \\
\hline Promethea Moth & . & • & - & •* & • & • & " & \\
\hline SHOWY LADY'S SL & IPPER & - & • & $\bullet$ & $\bullet$ & • & " & \\
\hline MONARCH BUTTERU & FLY - & KIN & & & • & & $"$ & \\
\hline WINTER's ROBIN & - & . & • & $\bullet$ & • & • & " & \\
\hline
\end{tabular}





\section{RAMBLES OF A CANADIAN NATURALIST}

\section{AN OPENING WORD}

LITTLE straggling patches of shrubbery and lingering trees that hide timidly in the shadow of a great city, streams destined for imprisonment in long dungeons beneath the paved and crowded streets, marshes striving in richness of verdure to convert each year's decay into new and healthy life, all tempt the rambler to push his way about and linger over the intricate and changing panorama.

The few miles that bound a morning's ramble seem so limited and circumscribing, and yet so vast-so crowded with an infinitude of nature's activities. Let us look, let us listen, let us breathe the enriched air. Myriad forms of the mystery of life crowd upon the senses made keen by the silence. Rambles merge imperceptibly into ramblings, and the little clumps of brushwood seem peopled with the wild things that have long since taken their departure to the secluded shades of the distant and retreating wilderness.

This is not that blending of fact and fancy which 
pains the conscientious naturalist, but simply a mental assimilation of sights and sounds. What is seen and heard-things revealed to the eye and earmay awaken a delighted interest, but our thoughts and fancies, stirred by what is partly revealed, have a deeper charm. Following these suburban rambles may yield the keen pleasure of observations verified. And perhaps in the wayward ramblings a community of fancy may be discovered more pleasant and more fraternal than the kindred joy of disclosing nature's guarded secrets. 


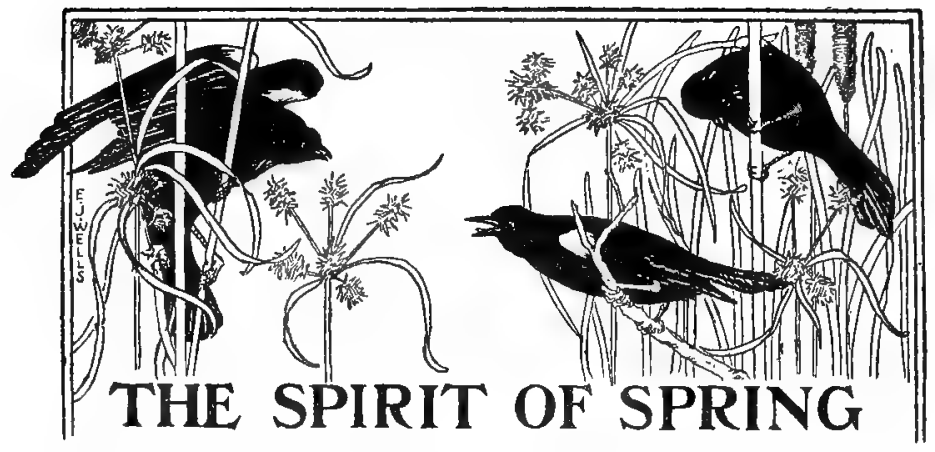

WHEN the long, grey mornings of spring renew their invitation they cannot be denied. Snow lingers in secluded corners and frost is still in the ground, but spring is awaiting a welcome. Robins are househunting among the naked trees. Red-winged Blackbirds are perching on the dead reeds, displaying their glossy uniforms and scarlet epaulets, or trying their shrill voices from the higher perches in the willows. The Song Sparrow is here, his familiar call an earnest of the new life awakening on every hand. The Bluebird is displaying his finest colours, and seems tempted by his vanity to choose the open fields and solitary, leafless trees, where he can compel the admiration of all observers. The Fox Sparrow is shy and retiring, but his spring song brings a world of delight, although he is hidden in the thicket. The pussies on the Willow twigs are pushing their little grey noses from under their reddish brown hoods. The long catkins on the Alders are showing signs of 
life. A broken Sassafras twig fills the air with one of the most delightful of forest odours. It is hard to resist the boyish impulse to cut a Maple and taste the sap. But it is no more tempting than the perfume of a growing twig of Black Birch, broken where the winter buds are swelling. Nature has been dreaming under the white mantle that has just been drawn aside. Moss is melting holes for itself through the ice. The Wintergreen is all about in profusion, carpeting the ground with rich green leaves, dotted here and there with bright red berries. It has defied the frost, the snow and the ice of winter, and now offers up its tempting berries, pleasant in flavour and odour as they are beautiful in colour and contrast.

The Trailing Arbutus, too, has a vitality that defies the winter, and its green leaves are showing above the litter of last year's vegetation. Those who are robbing the suburban woods of this flower have a great $\sin$ to answer for, but the temptation also is so great that one cannot but forgive them. The flowers are already formed and the pinky white is protruding from the little green buds. In a day they will be opened, the sweet perfume leading to their destruction by revealing their hiding places under the dead leaves. The man or woman who can pass a Trailing Arbutus in flower and not pluck it is as near to perfection as it is possible for weak humanity to approach. Down by the swampy margin the ice is 
receding from the shore, and the Watercress is there fresh and green, showing that the stream has been but dreaming all winter. The Skunk Cabbage, that beautiful and malodorous flower, is already raising its variegated hood from the black mud. It is determined to be first among the wild flowers. On the shore there are some small Sassafras trees completely girdled at the ground and doomed to die. The Cottontail is at once suspected, which shows the evil of a bad name. But there are Muskrat houses suspiciously near, and many evidences of amphibious activity in the half-frozen mud. Have the Muskrats been guilty of these depredations? The multitude of tiny wounds show that the culprit was the little Shore Mouse with the formidable name, Arvicola riparius. The leaves of the Hepatica are frozen solidly in the ice high up on the bank, but alive and well withal, and destined for a life of usefulness throughout the summer. What wonderful egotists we must have been to think the three-lobed leaf of the Hepatica was shaped to intimate that it could cure certain human ills. As if our little ills were sufficient to move the mighty indifference of nature! The Hepatica is as indifferent to our petty needs as the Downy Woodpecker sounding his gong on the resonant oak limb or the Lordly Crow moving with steady strength across the colourless sky. 


\section{THE SKUNK CABBAGE}

Along the oozy margins of swampy streams, where spring seems to detach the sluggish ice from the softening mud, the Skunk Cabbage is boldly announcing nature's revival. Handsome, vigorous, and strong, richly coloured in purple, with delicate and sometimes obscure markings of yellow, it rises clean and unspotted from the weedy mud, a pointed, bulblike flower as large as a lemon. Its twisted, oval contour and smooth-coloured surface suggest an overgrown shell. But its chief claim to recognition is its eagerness to greet the spring. In fact, it never waits for the reviving warmth, nor even for the inspiring spirit of the season of nature's renewal. In late autumn it rises from the black or mossy dampness to live safely under the snow and be first in spring's revival. The great, round bud sitting comfortably on the thawing ooze or rising through the lifted ice is not only a promise of spring, but an assurance of nature's perpetual activity.

The bulb-like flower is soon attended by an adjacent green cone, formed by a closely-folded leaf. But before the leaf develops, the handsome purple shell, which is thick and fleshy, withers and falls, 
revealing the enclosed spike on which the real seedproducing flowers are clustered. The leaves develop later in the season, when they give some of the marshy hollows a distinctly tropical aspect. Large, oval, and pale green, often more than two feet in length, they rise from the buried root-stalks that bore the flowers in early spring.

The Skunk Cabbage deserves its quite uncomplimentary name, for even its devoted admirers, who seek it as the earliest of all the awakening flowers, feel constrained to apologise for the odour it exhales. It generally escapes the indiscriminate destroyers of flowers, for its attractive colours begin to fade before they are abroad. It chooses inaccessible places where the treacherous mud is a safe protection. Its odour, too, is a means of defence. And its great, fleshy, tropical richness and strong colouring seem quite disappointing when taken from their natural surroundings. Sometimes a rubber-booted boy is seen walking proudly through a swamp or along a footpath with the prize in his hand, carried by the invariably short stalk, and suggestive of the utility of fruit or vegetables rather than the ornamentation of flowers. The perennial root-stalk, deeply buried, insures the perpetuation of the Skunk Cabbage. And with each returning spring its favourite hidingplaces will be sought by all who long for the earliest news of the great awakening. 


\section{THE PITCHER PLANT}

THERE is a human interest in this peculiar inhabitant of swamps and bogs. Its pitcher-like leaves, mysteriously full of water, graceful in form, and delicately marked with purple, red, and brown, its carnivorous habits, its round, rich, purple-red flowers nodding on their tall and solitary stalks, all serve to give it character and make a visit to its favourite haunts a memorable event. The sphagnum swamp which a utilitarian age would desecrate by transformation into briquettes of peat fuel, the swamp where the Pink Lady's Slipper grows, where the carnivorous Sundew is found, and the Pyrola and Lady's Tresses perfume the air, where the elastic, spongy carpet of moss is so yielding that a visitor feels impelled to keep on the move, while a heavy tread shakes the neighbouring Tamaracks-there is the home of the Pitcher Plant.

The Pitchers are now thawing loose from the surrounding snow and ice, but the frozen water has not burst the yielding leaves. They will survive the early summer and sustain the flowers until a new set bursts through close to the roots, when the older Pitchers dry up and return to the swampy soil. These 
plants draw sustenance from many insects enticed into the Pitchers by their honeyed lips. Once inside, the venturesome invader is doomed, for the throat is armed with a formidable coating of sharp spines, pointing downward. These facilitate the descent, but make return to the open air impossible. The struggling victim, in his futile efforts, is caught on one of the sharp spines and thrown into the water, where he speedily succumbs, nourishing the plant that enticed him to his fate.

The water in the Pitchers has a digestive effect, and the plant draws nutriment from the insects dissolved in it. But the resources of the insect world are infinite, and some diminutive visitors contrive to make of the threatening death-trap a comfortable dwelling. When a mass of undigested wings, legs, and armour plates of the invading insects accumulates in the bottom of a Pitcher an enterprising fly of the genus Sarcophaga finds in the refuse a suitable habitation for her coming brood. She enters without any trouble, deposits her eggs, and, by a strange dexterity, makes her escape again. When her young brood hatch out, the larvæ feed on the accumulated remains, and in due time make their escape, regardless of the barbs that threaten to impale them.

These sojourners are harmless and perhaps beneficial to the plant, but another tenant, a small moth, lives at the expense of her habitation. She goes 
in and out without the least difficulty and lays her eggs on the inside of the open lip, in free defiance of its array of concealed weapons. When the young larvæ come out they feed on the inner lining of their Pitcher, working around with a delicacy and care that suggests a knowledge of their imminent danger. They eat away a ring of the inner surface, clearing off the dangerous spines that would throw them down into the water, and all the time spinning a carpet of silk to afford themselves a secure footing. After a while the weakened lip shrivels and collapses, thus making a comfortable habitation in which the young moths sleep through the pupa stage of their existence. They then emerge from the shrunken covering to seek in other Pitchers a home for the next generation. There is also an insect of the Hymenoptera order that makes a home in this charnel-house of her relatives. This enticing death-trap is found to be hospitable to at least three visitors from the insect world. Perhaps it is this natural blending of what we call good and what we call evil that awakens the deep human interest in the cluster of curved, open Pitchers nestling in the moss and trailing a few roots down to the unseen water. 


\section{BIRDS OF THE SEASON}

EARLY messengers of spring are all the more welcome through the season's wearying delay. The Robin we all know, for the city's vapours have no terrors for him. Sometimes he loiters quietly about all winter, showing himself occasionally to awaken delusive hopes of spring. The noisy, vigorous, and showy Jays remain through the winter, gathering food from many sources, and sometimes appealing to the kindness of suburban residents. Woodpeckers never desert us, and the Shrikes and Owls we have always with us. The hasty Snowbirds seek the open spaces in irregular flocks, searching for scattered seeds on the black ridges of naked earth. But when the timidly confiding Bluebird displays his rich colours in the suburban orchards and fields it is a material sign that the spirit of spring is in the air. A pair found their way to a favoured valley recently, and sought out the most tempting southern slope, where the high, curving bank tried to concentrate and retain the rays of the afternoon sun. There were patches of naked earth, where the atmosphere quivered with the reviving warmth and blurred the outline of the open shrubbery in the close background. The 
melting snows revealed the litter of the past season's vegetation. The uncovered ground was thawing in exposed places; and the root leaves of the Asters showed bright and green under the receding edges of the icy covering.

But this did not seem a satisfying assurance of spring to the new arrivals. They perched restlessly on the dead Mullen stalks, and flew timidly back and forth among the entangled thickets of Oak and Hawthorn. The rich blue of their plumage contrasted alternately with the broad expanse of snow and the patches of naked ground on the hillside. Bright sunlight deepened the dull red of their breasts. The spirit of spring seemed struggling for recognition, but they would not respond with a single note. The sun beamed on them, and traced distinct shadows on the dazzling snow, but they refused the slightest responsive sound. A whistled call they treated with absolute indifference. Evidently their day of song was away in the future. But, silent and dissatisfied, they were still welcome, and fancy supplied the song that will be heard in the suburban orchards and along the country roads when the season fulfills its mission.

More responsive is the Horned Lark, for he often remains throughout the winter. His vocal notes may be heard as he makes his undulating way over the snow-covered fields. Like the Bluebird, he is midway in size between the Sparrow and the Robin, but 
the colours, seen as he runs persistently along the ground in front of an intruder, are uniformly dull and grey. He is lighter on the breast, with pale yellow and black toward the neck, and the small projecting points of feathers over his eyes have given him his name. The black tail is a conspicuous mark of identification for both males and females. The Horned Lark nests on the ground, sometimes even choosing a sheltered spot on the roadside. In spite of this open confidence, and his apparent indifference, at a respectful distance, he does not become, like the Bluebird, tolerant of familiarity on longer acquaintance. His suspicions can never be set at rest, and when he runs ahead along the ground no seductive coaxing can induce him to permit a nearer approach. But he calls so early in the spring and attends so willingly to his own affairs that he can be forgiven for even the deplorable offence of suspicion. 


\section{UNAPPECIATED FLOWERS}

WhILE the obdurate frost still holds the bulbs and roots of early flowers in its rigid grasp, many trees seem determined to respond to the promptings of the season. In and about the city the flower buds of the Soft Maple are freely opening and studding the intricacy of twigs with bristling tufts and bunches. Where the tracery of small branches was free and open a few days ago the view is now obstructed by the accumulation of small, unappreciated flowers. But they are real flowers, and that brings them into fellowship with the season of awakening life. Flowers are associated in our minds with the richest textures, and with colours surpassing fancy in their effulgence and delicacy. But the sturdy branches overhead have a floral richness of their own, modest and unadorned, yet claiming a place in the scheme of perpetual transmission. In spite of the forbidding aspect of the season, the Soft Maple flowers have already unfolded, the more vigorous and eager male trees defying the chilling reception of lingering snow. The female trees are more reluctant and hesitating, content to come forth only in the most favoured localities. This exclusive arrangement is by no means universal with 
the Soft Maples, for the male and female flowers are sometimes seen on adjacent branches of the same tree. And on rare occasions a little bunch of co-eds will appear, surrounded on all sides by their vigorous, crowding brothers. Although these Maples scatter their seeds and germinate before summer dries the ground, the bud scales strewn about do not indicate that the flowers have fulfilled their mission. Early birds have missed the delicacies usually provided by the season, and have turned in their extremity to the unpalatable buds.

Elm flowers are also opening in favoured localities. They are shy blossoms, and, like some of the most elusive warblers of summer, prefer to remain partly hidden in the tops. There the swollen buds are now visible against the cold grey sky, and occasionally on a more ambitious limb the rough, uneven clusters show where the flowers have actually unfolded. If their delicate stigmas do not succumb to the cold they will soon be strewing the ground with roundwinged seeds.

Alders by the suburban streams are bringing a far different variety of floral offerings. The rigid catkins that were as hard and lifeless as thorns through the winter seem suddenly to have thawed out with the return of spring. They have become large, loose, elongated, and flexible, and as they sway about with every passing wind, the bright, yellow pollen shakes 
out from a multitude of openings in their sides. The pussies on the Willows have come out confidingly in many places, but seem to have been chilled and discouraged by the lingering winter. These, too, are flowers, greeting the returning sunshine with all the eagerness of new life. In a short time the male and female trees will be easily distinguished as the catkins turn yellow or red. And as the season advances and the yellow catkins fall to the ground, the fertile trees will bear bundles of diminutive pods, bursting with the airy, cottony wings that carry the seed away on the passing breeze. The spirit of new life among the flowering trees is struggling in the tenacious hold of winter, and sympathetic nature feels already the thrill of its certain emancipation. 


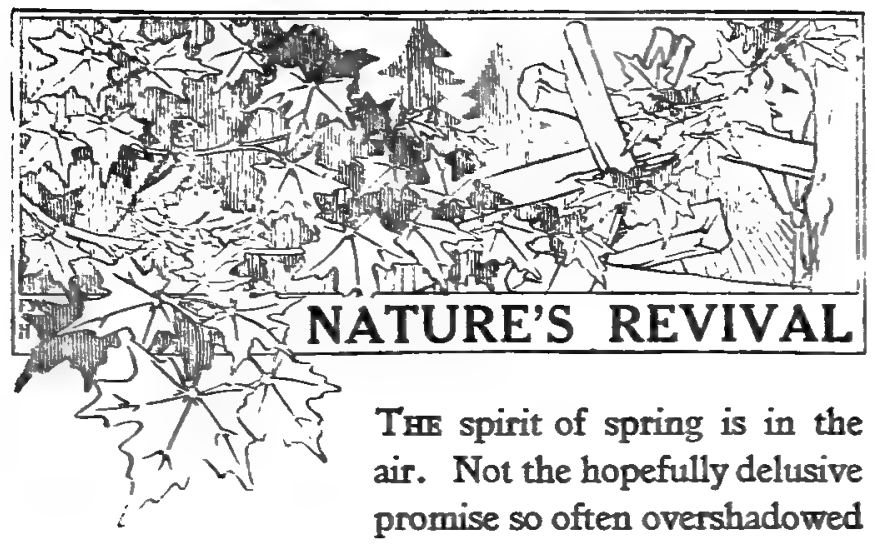

by delays and disappointments, but the real spirit that breathes life to all animated Nature. There is something universally contagious in the awakening of Nature. The piping call of a Robin, or even the silent opening of a bud, awakens the insistent thrill of fellowship in the mystery of life. The solitary messengers of a week ago have been followed by advancing flocks, and some have already assumed their old aspect of familiarity. Robins are hurrying up the valleys and over the adjacent hills, active and energetic, but obdurately silent. Fences, trees, and shrubbery, roads, lanes, and open fields-every available resting place is tried in impatient succession, but through the active communal life of the new arrivals there is an uneasy suspicion of human intruders. The communism of the gathering flocks will soon be lost in 
the song of the builders as they prepare their several domestic establishments. We regret the departure of the Robins, when great flocks assemble in the suburban woods. But their southern journeying absolves them from the taint of continuous domestication.

A scattered community of Bluebirds has appeared close to the city, moving about with a quiet complacency that befits their rich attire. Unlike the Robins, they do not crowd together and follow a restless leader, still they keep within easy call. Familiar habitations of last year in orchards and woods, abandoned excavations of the woodpeckers, hollow branches and decayed trunks, all are sought again by the quiet stragglers. Their call is the voice of spring, but they linger, reluctant to desert the flock. Horned Larks gather in flocks, feeding where the snow has melted from the strewn fields. Enticing notes are in the air, and already the successful wooers are separating from the flock with their mates, and seeking convenient nesting-places on the exposed ground. The Horned Lark is a model of domestic attention, and his bright, ecstatic song, as he circles and rises above his hidden mate, often reveals the carefully located nest.

There are other spring voices in the air. A Purple Finch announces his arrival from a sheltered perch, and a Kildeer cries from the sandy shore by the 
marsh. This returning wanderer should be welcomed for the great range of his travels. Not content with seeking a comfortable climate for the winter, his restless spirit impels him to go on southward through Mexico and along the isthmus into South America, and across the equator to where the months of northern winter bring a rising temperature. The insatiable energy shown in his swift, eager run along the shore, his cries of alarm when taking wing, his unending calls and sustained flights reveal the spirit that prompts his long southern journey.

Spring recalls the peculiar ways of our migrating visitors. We have some that travel in an indifferent way, varying their habits with the season's temperature. They merely grow less numerous toward the north in winter, while appearing in greater numbers in the warmer zone. Excessively cold winters bring down the Purple and Evening Grosbeaks, the Canada Jay, and Snowy Owl from their northern retreats. Some, like the Robin, leave an occasional straggler behind all winter, while the majority spend the season in the Southern States. There are Plover that go to the extreme limit of Patagonia, returning in response to the same strange impulse to breed within the arctic circle. There are Waders that migrate with a regularity that would suggest a personally conducted tour or some kind of systematic organisation. Some aquatic birds have very irregular habits, depending 
largely on the accidents of a food supply. But the returning pilgrims are always welcome. The spirit of nature's renewing is in their voices. The joy that thrills in an endless multitude of tones proclaims the universal fellowship and kinship of life. 


\section{A SUBURBAN RAMBLE}

THE call of spring is irresistible. Many who never see the snow-laden Spruces and naked Maples fixed in the crystalline atmosphere of winter, when silence broods over nature's white coverlet and her sleep is undisturbed, awake with the call of the Crows and the happy greetings of the Robins to a knowledge of the great out-of-doors. Suburban ravines and wooded spots that escape destruction in the shadow of the city welcome again the eager visitors, happy in effecting a momentary escape from noise and turmoil. Robins are happily announcing their hopes and prospects. Crows are passing overhead with steady flight, heralding the arrival of spring, or alighting to discuss prospective domestic affairs. A Downy Woodpecker pounds on a resonant limb, as if his scarlet crest and mottled wings were not enough without boasting his industry to the coy little bunch of feathers beyond the Cedars. The Song Sparrow is everywhere. He comes more than half-way to greet the suburban wanderer. When the Thrushes come we will sympathise with their coyness and subtler melodies, but for the strong and virile spring we must have the Song Sparrow, perched on the highest 
branch he can find, looking up into the sunshine and pouring out the ecstasy of a glad heart. Though abundant everywhere and profuse with his melody the Song Sparrow is always welcome as the spring. No other songster so well interprets the spirit of the season.

Some less familiar visitors are active in the suburban brushwood. The Junco, dull and darkly grey, is yet conspicuous among the naked branches. $\mathrm{He}$ is singing now, and his low warble has the charm of rarity, though but a modest musical performance. The Junco's light brown beak seems an odd contrast with his dull colours, and he makes an enlivening display of white feathers as he flits into the Evergreens. Nuthatches are creeping about on the Oaks, picking out the cocoons that are ready to awaken with the returning warmth - the brightest of the winter residents, who draw near in pity with the advent of spring.

Among the scattered decay of the past year there is abundant evidence of nature's foresight. The ground leaves of the Asters have sustained their vitality under the snow through the long frosts, and are showing signs of renewed youth. The Wintergreen has not even condescended to droop a leaf or stem, and its scarlet berries are shown in contrast against its rich green leaves. The Pipsissewa is also strong and erect, as bright as its melodious Indian 
name. The Hepaticas come out as if they had enjoyed the winter. Their characteristic leaves are full of vitality, although their stems may droop. And in the centre among the stems the rising woolly bunches are reaching up, preparing to unfold the delicate flowers already impatient for the early sun. The Trailing Arbutus is still more eager, though advancing more quietly under the dead Oak leaves. Where an occasional leaf shows only a hard vitality, a careful search close to the moist ground will disclose flowers already open, showing delicate white and pink and enriching the air with perfume.

Rich red patches on the Silver Birch show where vandals have robbed the trees of their beauty. The sublime egotism of the human name, at which the greatest of all egotists in modern literature marvelled, is seen in the initial letters with which the bark is defaced. More stirring to the fancy is a cabalistic design cut with care and regularity in the white bark. It is not the insignia of any secret order, inscribed in the enthusiastic faith of a neophyte. There is no clue to the intent or purpose of the strange marks. They are hidden away in the loneliest spot, in contrast with the conspicuously displayed initials. Fancy and speculation are dampened by the multiplicity of influences that prompt humanity to action. In the nibbled bark of a broken limb we see where the Field Mice, driven from home by the recent floods, 
have been forced to live on coarser food. Holes drilled by a Woodpecker in search of insect food are of obvious purpose. Throughout all the activities of the lower orders we see the regular sequence of cause and effect. In the distant forest a mark on a tree will show where a deer has rubbed the withered velvet from his horns. But who would attempt to fathom the multitudinous impulses that have prompted a lonely wayfarer to carve with evident care a peculiar design on a Silver Birch in the most secluded hollow of the suburban woods? 


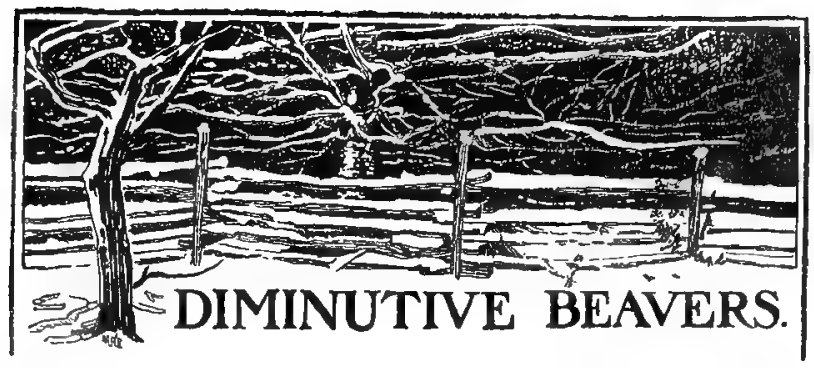

THE drawing of winter's curtain always reveals a multitude of silent activities. Nature has not been dead nor yet sleeping, but has been quietly active through the long months of snow. The root leaves of Asters and Goldenrods are green and vigorous. The Evening Primrose has withstood the frost. The Dandelion is green with promise. All the evergreens are awaiting a welcome. But the revelations of animal activity are far more interesting. Ramified burrows of the little Field Mice and Shore Mice are still preserved in the melting masses of icy snow lingering in shaded hollows. These little fellows are not really Mice, but they are so diminutive that it seems ridiculous to call them by the aggressive name "Arvicola." They are closely related to the Beaver, and during the long winter have made an unusual attempt to imitate the ways of their big, industrious cousin. They have not been content, as usual, with girdling the small trees under the snow. In many places they have cut down shrubs as thick as the 
finger and cut them up into irregular lengths, as if contemplating the construction of a dam.

The destructive industry revealed by the melting snow is phenomenal. The Sassafras has been one of the chief sufferers, its aromatic bark being a special temptation to the little marauders. Many promising young trees are completely girdled, and the deep abrasions extend in irregular patches up their trunks to the winter snow line. These mutilations show countless diminutive tooth-marks and tell of the voracious energy of the tireless rodents. They have not been content with gnawing at the odorous bark of the Sassafras. The white wood of the Alder shows in irregular girdling patches, contrasting with the smooth black bark. The Sumach, too, an unusual article of diet, has served for much feasting under the snow. The smaller branches, buried within reach, have been cut up into irregular short lengths and lie about in careless piles. All the bark has been eaten from these little logs, and the wood is often gnawed away to the soft pith. Where the piles lie in the dead grass there are well-preserved remains of comfortable nests under the snow, and regular runways are still clearly marked in the frozen ground. The Wild Raspberry is a still more unusual article of diet, and suggests a world of trouble over the problem of a food supply during the long winter. Many of the bushes have been cut down, and the bark and even 
the thorns freely eaten. The branches selected have been cut into lengths of two or three inches, and each heap shows the location of a permanent camp.

The long winter has been a severe trial for the little world out of doors; and the debris of so much industry naturally prompts a feeling of pity for the workers struggling with the problem of problems. But sympathy is generally misplaced. It may be that the great depth of snow was an assurance of safety and comfort, allowing them to remain quietly in their little camps while the great barking and sniffing disturbers rushed noisily over their heads. An energetic dog, running about on the snow, can keep a whole multitude of these rodents on the move in their burrows. The permanent camps of the past winter may reveal a season of exceptional comfort and leisure, with no intrusion from the meddlesome world that moves in the daylight above the snow. 


\section{THE AMERICAN MERGANSERS}

THERE is a steady purpose and untiring energy in the flight of Wild Ducks, whether they move in dotted alignment against the distant sky or stare in suspicion as they pass low, with straightened necks and stiff rapid wings. Their full, heavy bodies and small, pointed wings make flight a serious effort, quite unlike the indolent soarings of the Gulls, the steady undulations of the Herons, or the restless irregularity of the inhabitants of the woods. They freely range the continent from the arctic shores to the tropics, making homes, according to their varied inclinations, on the rocky shores, in the concealing marshes, in trees, by hidden streams, and on the open prairie. Most conspicuous in this varied family are the American Mergansers, and a small detachment have already arrived in search of summer quarters. Their narrow-toothed bills indicate a fish diet, and this has saved them from pursuit, but the conspicuous beauty of their plumage and the graceful curves of their changing attitudes are temptations to the predatory. They swim about the edges of the weakening ice, their red bills reflecting rich tints in the sunlight, their heads of dark metallic green glistening like 
burnished metal, and the creamy white of their long necks and full shoulders showing in varying outlines. Such a profusion of white in the bright glow of a lengthening day is a conspicuous reminder of the return of spring.

The leader of this small advance guard was attended by two sombrely attired females following faithfully in close alignment. He looked suspiciously at the open water in the marsh, where many noisy Gulls had congregated, but was not inclined to alight. As he turned toward the open water of the lake, passing low over the sandbar, the faint red glow of his breast seemed a reflection from the sun's rays struggling through the clouds rather than an actual tint in the shield of white. Out over the lake the rapidly diminishing forms of the trio showed the speed of their retreat, but their course was a great circle, which brought them again to the open water of the bay. The detour had given them confidence, for they settled easily to the surface, checking their speed with expanded wing and trailing, splashing feet. There must be concerted action or a wide response to local attraction among the migrants. The three were scarcely settled in the water when three more, all males in full plumage, came along the eastern shore line in earnest haste. With scarcely a hesitating curve they pitched down beside the earlier arrivals. These Mergansers are uncertain migrants, and seem more 
eager for safety than for the remoteness of the north. They have been known to nest about the big lake in happier times, and they still find safe concealment on some of the sheltered rocky shores of the inland waters. In early spring, when the lingering ice gives an aspect of contrast and relief to the life of the awakening year, these graceful swimmers in rich and full plumage appeal for respite in the eager work of destruction. 


\section{THE AWAKENING YEAR}

THE darting and hilariously erratic flight of the Swallows is an assurance that spring is really awake. Other arrivals have promised and predicted, but the Swallows have made an actual announcement. The Meadow Lark, with sweetly modulated whistle, has announced the good news from the south, and has tip-toed in the stubble, displaying his yellow breast. The Flicker has cackled his loud and long alarm, and the Robin has varied his noisy piping with sweet and restful melody. The Bluebird has chirped in mild exhilaration, and the Blackbird with scarlet epaulets has brought life back to the withered marsh with his keen-edged, penetrating call. The melody of the Song Sparrow has overflowed everywhere in rich abundance, and the Vesper Sparrow has followed to take possession of the fields. All these are promises and forecasts, and they have been strengthened and supported by renewed activity on the part of the Juncoes, Downy Woodpeckers, Brown Creepers, Nuthatches, Kinglets, and other hardy winter residents. But the real announcement of the actual awakening is the darting flight of the light and swiftwinged gleaners from the air. 
The high bluffs of clay and sand, with their happily preserved but threatened fringe of woods, seem to attract the early arrivals among the Swallows and Flycatchers. Perhaps it is there that the lengthening rounds of the slowly mounting sun have greatest force in prompting an early awakening of the ephemeral life on which these sojourners must subsist. Where the absorbent sand dries the surface and the still air grows warm and quivers under the steady glow of sunshine, the insect life awakens from its strange torpor. This response to the new invitation is revealed by the daring swallows pursuing the multitudinous population of the air over the warming fields beside the fringe of woods. These new arrivals are the pioneers of the coming migration. Two Barn Swallows, the most beautiful of the family, display their glossy steel-blue mantles in the sun, their long and deeply forked tails bending gracefully as they chase their invisible prey. Their reddish breasts make a contrast to the white breast of the one Tree Swallow that accompanies them. His blue-green mantle shines like burnished steel with every curve and turn, but even in the distance his shorter and less deeply forked tail distinguishes him from his companions. All the birds of day respond to the sunshine, which seems to multiply their numbers, for they remain unseen on their quiet perches when the sun is hidden by discouraging clouds. These swallows, 


\section{THE AWAKENING YEAR}

joying and glorying in the sun that is sustaining the hope of their long southern vacation, make the welcome announcement that the air at last is filled with the swarming life that responds to renewing influence of the sun. 


\section{THE VOICE OF THE SILENCE}

IN the city kindly nature dulls the hearing, that an infinite medley of jarring noises cannot torture and distract the long-term prisoners beyond the bounds of endurance. The great jumble becomes inaudible, like the roar of Niagara to dwellers in its vicinity. But once beyond the screaming of trolleys, the pulsating thunder of locomotives, and the subdued din of industrial life, the senses awaken and the many voices of the woods grow distinct. Although every bird-call blends naturally and harmoniously with its surroundings, it comes clearly to the ear, bringing a message of conscious life, separate and distinct, but still a part of an all-pervading, harmonious sound. 'The spirit of growth is in the air. Do we hear the rustle of its countless vibrations newly-awakened or only feel the throbbing energy of its presence? Perhaps it steals upon us through senses far more subtle and mysterious. The silent Robin on the naked limb seems listening to the sap surging through the solid trunk beside him. But along comes a Sap-sucker with spasmodic flight and dispels the delusion by going to work in a most methodical way. His membership in the Wood- 
pecker family is apparent, but instead of seeking a dead trunk for wood-borers he digs for the sap in a healthy, vigorous limb. Perhaps he uses the sap to tempt insects. There he plies his noisy trade, while the inconceivable power that forces the juice through the solid fibre of the wood is exerted in perfect silence. Not even the Robin's ear, said to discern the moving of an angleworm, can detect the sound of the flowing sap.

Put an ear to the trunk and listen, for the close, attentive effort makes the sound of surrounding growth discernible. There are blended tones that serve as a grey, indistinct background for the rapping of the Woodpecker signalling to his mate or pursuing his unromantic vocation, for the twittering of the acrobatic Nuthatch, or the almost inaudible plaint of the Wood Pewee. There seems a mysterious sound in the silence, and it may not be altogether fanciful to regard it as the sound of growth. On the Soft Maple thousands of buds are opening, and their strong scales are not turned back without the jarring of minute resistance. Is it really the ear that discerns a many-toned rustle? Some of the scales and buds are already dropping to the ground, heavy with the saturating shower. The Elm buds, too, are bursting open, and making their activity felt or heard, and the elongated catkins on the Willows are throwing off the coverings that sheltered them through the winter. 


\section{THE VOICE OF THE SILENCE}

Hard scales on the Dogwood buds are starting and yielding reluctantly to the swelling pressure. The enfolded vegetation that lay dormant through the winter is awakening to life and throwing aside its manifold coverings. A thousand closely and compactly wrapped cones of leaves are forcing their way upward to the moist air, cracking and bursting the unyielding earth and pushing all obstructions out of their way. These myriad perforations can scarcely be made without an audible disturbance, especially in the spring, when even deliberate growth is impelled to haste by the spirit of renewing life. The sound of growth cannot be entirely a delusion. Growth itself may be absolutely silent. But the slow crowding aside of myriads of obstructions, the perforation and disturbance of last year's leaves, the cracking and opening of hardened bark, with the enlarging layers of new vegetation, the bursting of inelastic scales and husks - all these unite in a blended rustle of reviving life, through which the faintest squeak of the Brown Creeper or the twitter of a Kinglet comes clear and distinct. Listen! 


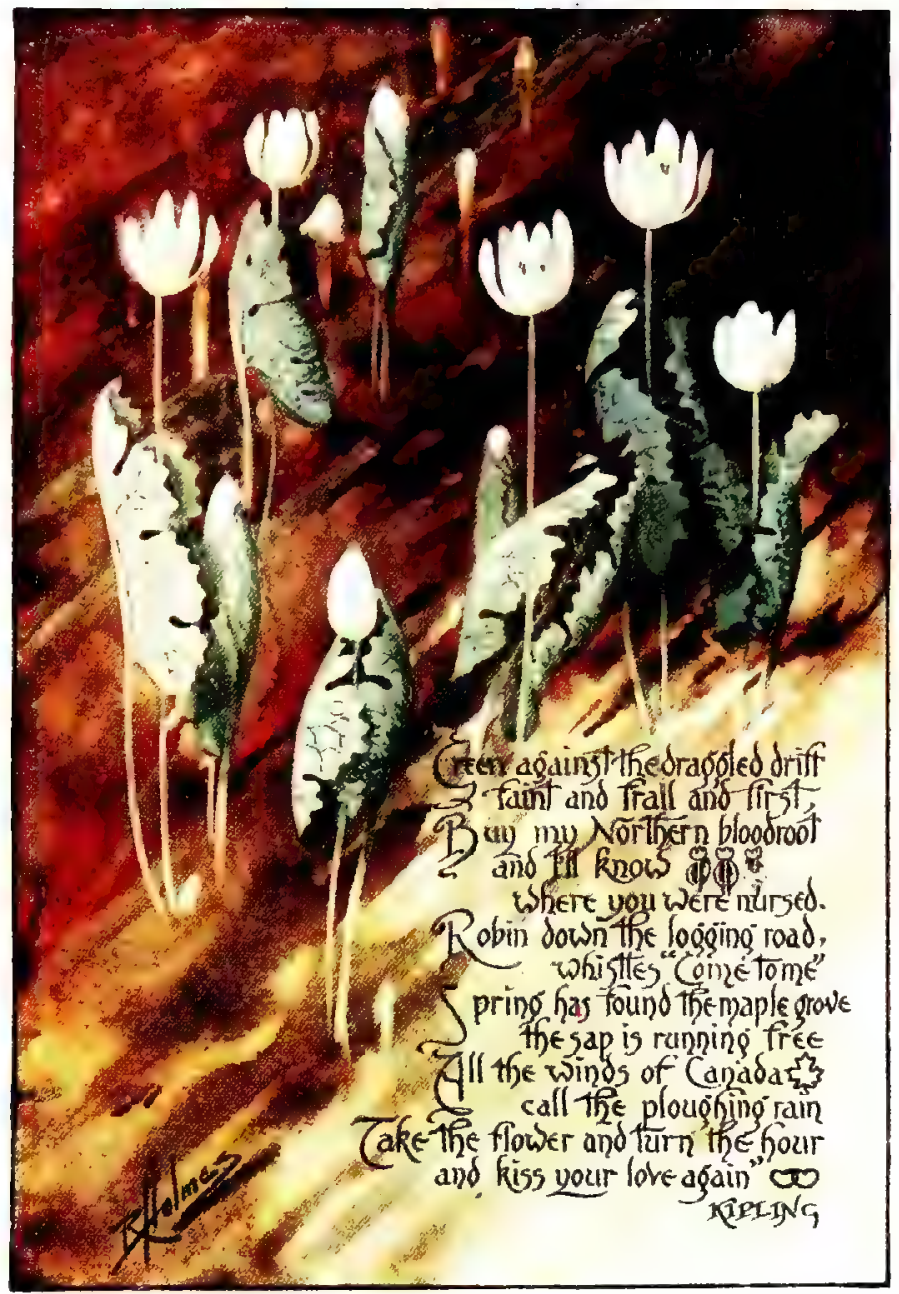

BLOODROOT 



\section{THE BLOOD-ROOT}

THERE is no richness in colour more appealing to the lover of the woods than these frail blossoms of pure white, scattered like stars over the dark, shaded ground, or looking out from among the lingering remains of last season's decay. The starry appearance is heightened when, shrinking from the cold or the threat of rain, they close into timid globes of white, without any green covering or protection. With the smile of sunshine they open again into eight-rayed stars, light and delicate, with yellow centres, timidly displayed to close admirers. The Blood-root has many charms. The flower that rises unprotected and temptingly delicate comes up through the earth enfolded in a single leaf. As soon as this leaf has carried the fragile treasure through the hard ground it begins to unfold, showing its rich, fleshy texture, dainty tracery of veins, and fine regularity of outline. Deeply and evenly lobed in a symmetrically rounded outline, it seems as beautiful and rich in life as the flower that passes from its folds up to the open daylight.

We cannot have the fine delicacy of the Blood-root without the weakness that allows only a brief span of life. The plucked flower droops, wilts, and sheds 
the white petals that botanists call sepals, almost before it can be brought from its natural elements into the harsh sunshine of the open roads. When unmolested it may have two or three days of life, or an adverse wind may scatter its white rays among the fallen leaves in a few hours. It is tolerant of transplanting, and when taken from its natural surroundings will live its allotted time in a shady garden. Under favourable conditions it will reappear with each returning spring as regularly as the yellow warblers that hurry invisibly among the opening leaves on the Elms and Chestnuts. If the thick, rough rootstock is wounded it bleeds freely, and the bright red juice which gives the flower its name makes a lasting stain. The Indians used it to heighten their colour, and after the influences of civilisation brought quieter tastes in personal adornment it was used in decorating baskets and ornaments of straw, Birch bark, and peeled Ash. Most of the original inhabitants have now degenerated to the use of aniline dyes, but the bright stain of the Blood-root is still admired. After the flowers fall the leaves grow large and strong, but never coarse, and the pods fill with rich, brown, glossy seeds. The more showy flowers of early summer are then abroad, but none can surpass the charm of the timid, inquiring Blood-root that rises carefully robed and folds back its mantle to come forth daintily into the dawn of the year. 


\section{"YA HONK! YA HONK! YA HONK!"}

THE supreme indifference of the Canada Goose to the cities and other slight blemishes on the continent he noisily surveys in spring and fall makes his passing doubly impressive. Sometimes in the multitude of noises against which the sense of hearing fortifies itself he brings his aligned flock quite near before his advance is detected, but he holds the entranced gaze until he has vanished slowly into the clear sky or thin horizon clouds, while the ear is still strained, hungry for the faint, fading, yet penetrating resonance of inspiring calls. He has grown more wary as man has grown more eagerly destructive, and instead of conveniently encompassing the continent and widely varying his summer residence and southern tours he moves determinedly in spring to the remote north, nesting by the interior waters of Labrador or the region west of Hudson Bay.

These magnificent birds yield reluctantly to man's encroachment. They still make bold to assert their prior claim to the prairie sloughs where the plough is relentlessly encroaching. In the warm, sheltered mountain lakes on the Pacific slope they still take advantage of the free choice of location afforded by 
an equable climate. Beside the recently advanced prairie railway a newly arrived flock from the south will crane their glossy black necks and display their broad, white throat-bands as the noisy locomotive charges past with its burden. The belching smoke is a hint to move another stage northward before disbanding to locate their summer homes.

The picture of a passing flock is indelibly impressed. They flew conveniently low over the tortuous hills, the leader holding his place at the head of the broad " $\mathrm{V}$ " with nineteen aligned on his right, and twenty-five on his left. There was a magnificent aspect of determination in those fortyfive necks strained rigidly forward toward the new home in the remote north. Calls of encouragement were frequently sounded and answered, and near the leader the steady flapping was varied by an occasional change of position. They passed so low that every distended pinion could be distinctly seen. Their heavy bodies and sturdy wings rapidly grew less distinct, and soon blended into a dark, wavy line against the low, thin clouds above the horizon.

The sun was still high and the atmosphere clear. Their calls did not seem to grow faint as rapidly as their outlines diminished. Soon in the concealing distance they faded and reappeared until they could not be distinguished from the shaded edges of the horizon clouds. As their calls still came back fancy 
followed them to the nests by the northern ponds, where they could carefully guard and conceal their precocious broods, where, helpless in the moulting season, many would fall easy victims of hungry Esquimaux and Indians, and where, with renewed strength, they would respond again to the strong call of the land of perpetual summer. 


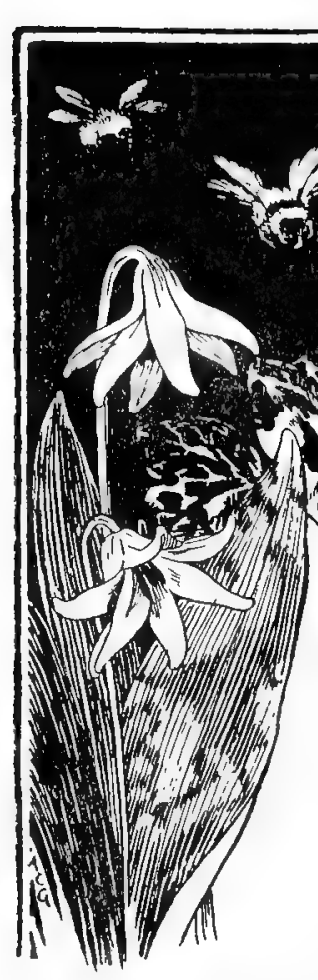

THE impatient wild flowers have come rushing and crowding to greet their friends after a protracted separation. Spring was so long unkind that they grew restive under her restraints, and now, with the first relaxation, they have hurried forth to display the profusion of their charms. The impressed order and decorum of the debutantes has been cast aside in their spontaneous haste for recognition. We look for the Hepatica to raise its woolly flower stems from among the surviving bunches of last season's leaves and display its delicate tints of pink, purple, or blue long before the single leaf of the Blood-root unfolds from the white flower it clasps and guards with 


\section{SUDDEN SUMMER}

tender care. We expect the Trillium to remain modestly folded awaiting her turn, and the Dogtooth Violet to be content with the faint suggestions of colour on its delicately mottled leaves. The Spring Beauty, too, though among the earliest, is generally content to await its due order, and the Trailing Arbutus, reclining cosily among the leaves and litter of the past year, may open its hidden buds at any time, according to the whims and fancies of the season. But now the favourites have all come forth at once. Long ago, as the flower season runs, the Skunk Cabbage, glorying in its lusty strength, pushed its way up through the lingering ice in the thawing bogs, regardless of the spring's delay. But this vigorous leader was not followed by the usual timid procession. Delay and disappointment marked the unfolding of the year until restraint became intolerable and the vigour of quickening life threw it off.

Where the sloping hillside seems to quiver in the reviving warmth of awakened spring the Hepaticas are relieving the dark dull ground with touches of delicate colour, from white and the palest of pink through many varying shades to pale blue. Trilliums are wide awake, too, not at all disconcerted by the general departure from established orders of precedence. The dainty sprays of the Spring Beauty appear like a belated sprinkling of snow on the leaf- 
strewn ground. On a nearer approach the apparent white gives place to a faint or decided pink. The pure white stars of the Blood-root have come out, and the hillside reveals them one by one, like the fading grey vault of the sky in advancing evening. There is another and another! Each star has come forth from an enfolding leaf of many graceful lobes and rich, green, fleshy, vegetable texture. This flower may last but a day, yet it is not always so short-lived. A cold night will close the white star into a firm bud, and in an uncertain spring a flower may open and close several times before the wind scatters its fragile petals. The leaves of the Dog-tooth Violet are freely unfolding, and here and there a spot of golden yellow reveals a flower bending over and glowing toward the earth from which it has just arisen. The Scented White Violet is peeping timidly from the shade of a depression in the hillside. There is a human interest in these offerings of spring, delayed so long and now crowding forward together. They appeal for protection. They cannot endure molestation, and, if plucked, will immediately wither and die in an appealing protest against such wanton aggression. Their mission is to adorn the earth that has nourished them into life. 

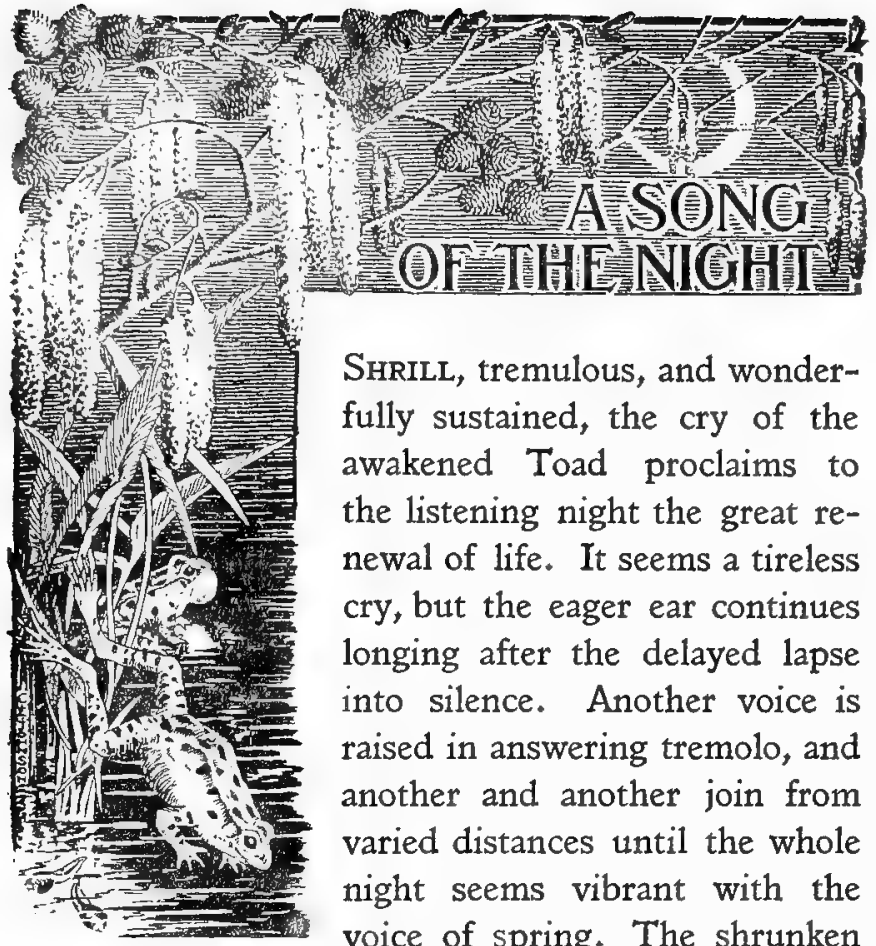

SHRILL, tremulous, and wonderfully sustained, the cry of the awakened Toad proclaims to the listening night the great renewal of life. It seems a tireless cry, but the eager ear continues longing after the delayed lapse into silence. Another voice is raised in answering tremolo, and another and another join from varied distances until the whole night seems vibrant with the voice of spring. The shrunken and belated moon looks slowly over the city-covered ridge and lights up the weedy pond. Diminutive ripples and irregular disturbances can be dimly discerned where the heralds of the new inspiration raise their heads above the glistening surface. The joy of new life after the long sleep of winter in the concealing, muddy bottom finds satisfying expression in these insistently mingled and musical voices.

"Ugly and venomous,

Wears yet a precious jewel in his head." 
Shakespeare never could have thought of the Toad as ugly or venomous had he known whose voice it was that told of spring to the silent earth under the belated moon. The jewel is a happy tradition. When a Toad sheds his skin, which, being a great economist, he invariably swallows, patches of new skin, generally on the head, present a surface of glassy smoothness. These, accidentally seen at a favourable angle in the moonlight, glisten like crystals of ice. As we know the Toads better and learn that their jewels are unreal we also learn to appreciate them for what they are. They are neither ugly nor venomous, and if they are not adorned with jewels they are gifted to charm the ear of spring with the sweetest of night voices.

There are other voices calling in the loneliness of the great awakening. The Leopard Frog must be a most impatient suitor, for his harsh, brief, colloquial baritone seems intolerant of delay. It is passing strange that a Frog so handsome in form and colour should find expression in such hard, aggressive tones. The little Hylas are almost forgotten in the loud and varied chorus. They are diminutive members of the family, but their persistence forces recognition. That shrill, gurgling " preep! preep!" repeated again and again in indifference to other expanding night sounds, tells where they are floating among the weeds, inflating and emptying their little vibrant throats. 


\section{A SONG OF THE NIGHT}

Soon these varied callers will leave the ponds and nature's warmth will hatch their jelly-covered eggs into black, wriggling multitudes of Polly-wogs. These will in turn discard their gills for lungs and their tails for legs, and will be prepared to settle into the oozy mud for the long sleep of winter. Now, from the moonlit, weedy pond, they invite the world to share in the joy of emancipation. 

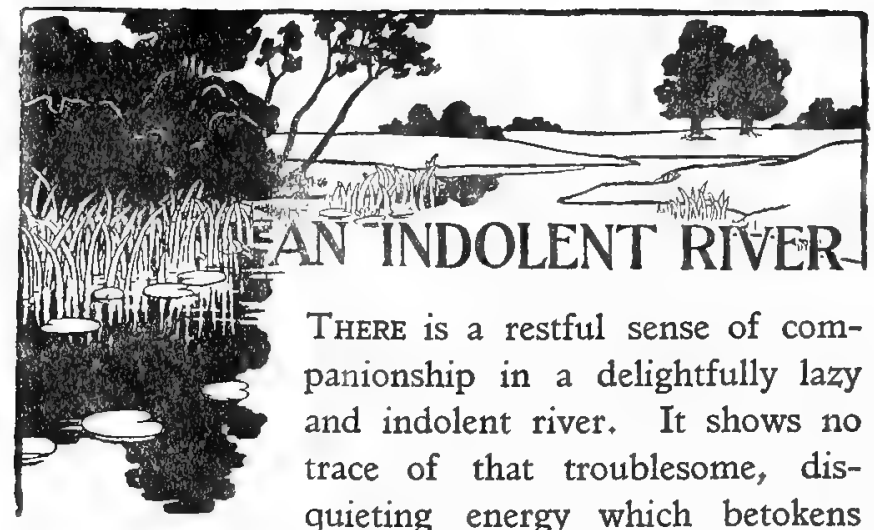

THERE is a restful sense of companionship in a delightfully lazy and indolent river. It shows no trace of that troublesome, disquieting energy which betokens an object in view. It never suggests the necessity of being somewhere at a certain time. Its art is not marred by a purpose. The vice of industry is foreign to it, and it lingers in the serenity of contentment. The Poet of Democracy sees national perfection "where none is industrious or respectable," and he might have found along this loitering river a perfect retreat to loaf and invite his soul. There are no straightened channels, no drained marshes, no landscaped banks, nor other manifestations of oppressive respectability, and the drowsy water lingers among winding banks of vegetation, where the remotest thought of industry would pass out in the sleep of satisfaction. The rushes grow lusty and indolent, purifying the decay of each succeeding season. The Dodder comes abundantly from the ground in the spring and clasps the growing Golden-rod, shaking loose its hold on the 48 
ground and climbing up, a parasite, on the sturdy herbage that will splash the shores with brilliant colours in the fall. The Scented. Water Lily, in all its glory, appears on the floating carpet of leaves in every pool banked off from the winding channel. The Yellow Lily, more vigorous and less dainty, challenges admiration by rising above the surface where matted leaves give a deceptive aspect of solidity. Smooth, worn portages at every curve show how these ponds are invaded by flower-gatherers, but Water Lilies defy extermination. Sometimes in early morning baby-like footprints and long, trailing grooves show where the Muskrats have passed over the canoe portages during the night. Helplessly diminutive footprints of the river mice are also seen in the soft mud. The familiar Marsh Marigold, the Water Arum, and the graceful leaves and fragile, white-yellow flowers of the Arrowhead stand in the shallow margins of the pools. On firmer ground the rich blue loops of the Closed Gentian hide in the marsh grass, and all the more confiding flowers come eagerly forward for recognition. The stream moves leisurely back and forth, touching the high banks with regular alternations, and rounding off marshy flats with quiet pools, where the flowers grow. Its own margins have no floral adornments - it is sufficient in itself.

Wild life lingers by the river, finding protection 
in the shadow of the busy city. The Mink, hunted everywhere for his handsome coat, finds a respite from persecution and grows fat and saucy at his ease. The slender Weasel sometimes comes out to ask the business of a passing canoe. The Skunk and Woodchuck excavate their cave dwellings in the high banks. The Red Fox sometimes braves the fate threatened by a bad reputation, and Squirrels and Chipmunks make the general quiet more subduing by contrast with their industry. The wary Blue Heron often rests in the shallow marshes, his white neck outlined against the dense banks of green. But he is mistrustful of man, and on the least threat of approach springs struggling into the air and takes his steady course to more remote haunts. The Bittern hides, invisibly seen, in the dense shelter, and sometimes rises with a fluttering rush from almost under the foot of a startled intruder. Rails and Gallinules chatter noisily in the marsh, and Blackbirds attend to their domestic affairs among the tall rushes. The Oriole finds an ideal swing on the drooping branch of an Elm, and the Flicker excavates a home in the decayed trunk of a Willow. The tiny Red-start moves like a live coal through the dense green shades. And when night closes in and the canoe moves imperceptibly with the silent water, the Fireflies come out and draw threads of light through the tall Rushes that bound the narrowed horizon. Frogs set up their weird chorus. 


\section{AN INDOLENT RIVER}

The Screech Owl flutters steadily across from one invisible tree to another. Bats dart, silent and swift, after the abundant swarms of gnats that float up from the marshes. All about is the quietness of nature, so impressive that the dull roar of a train, the far-away shriek of a whistle, and even the happy laughter from a lagging canoe, seem to blend and lose themselves in the inaudible noise that fills and soothes the ear of night. 

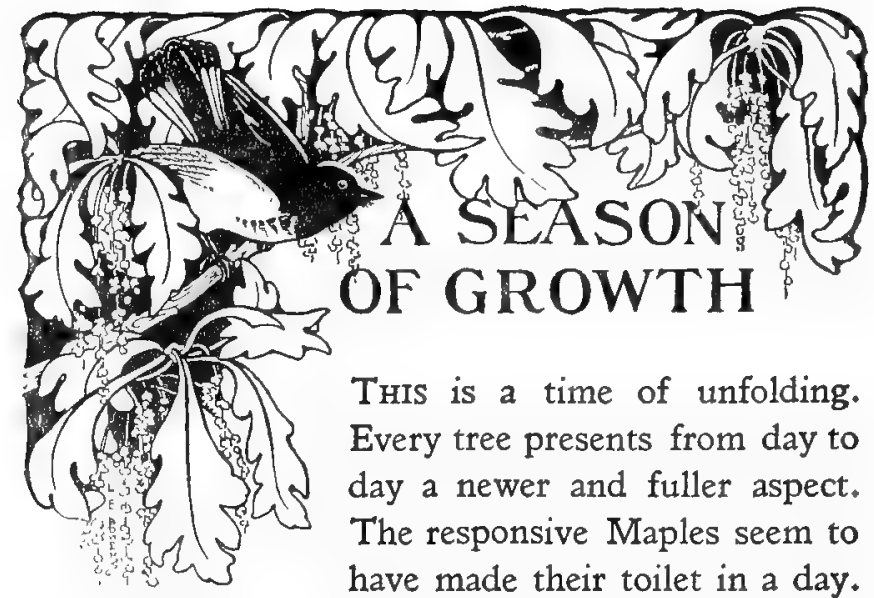

THIs is a time of unfolding. Every tree presents from day to day a newer and fuller aspect. The responsive Maples seem to have made their toilet in a day. It is surprising that they could draw their rich, green mantles about them so hastily and come forth adorned in such perfect taste. The neiwork of branches has been changed into thickening banks of foliage, blending and contrasting their many distinctive hues of green. The wind seems delighted to find leaves on the trees, and sports with them in renewed joy. It is a time when the great out-ofdoors is an all-inclusive invitation. The devoted worshippers of early spring who sought the first greeting of the Hepatica, the Trailing Arbutus and the Skunk Cabbage who listened for the earliest Song Sparrow from the south, are now joined by the less enthusiastic crowd who feel the call of the young summer. Caterpillars are pitching their tents in the Black Cherry trees. The Hermit Thrush is hiding quietly in the shrubbery. The Kingbird sits erect on a 


\section{A SEASON OF GROWTH}

conspicuous bough, ready to dart out after a wandering moth or butterfly. The Oven-bird sounds its familiar crescendo. The Veery, the most passionate and joyful singer of the woods, is announcing the arrival of summer. His call is indescribable, and leaves an impression of wonder at the power of a few connected notes. He seems to be churning his song in a resonant shell, and with each dash there is a swift outpouring of melody. Quiet indifference is his best safeguard, and while he is filling the shrubbery with his song and the listeners seek him in every direction, he is sitting on an exposed twig, his blotched breast and neutral colours blending imperceptibly with the background of opening foliage. The Red-start, too, brings a pledge of returning summer, winning a welcome with his open confidence, cheerful note, and handsome plumage. As he disappears in the underbrush the crescents of bright salmon on wings and tail make a sharp contrast with his coat of black.

The Huckleberry bushes appear green and new, the little cup-like flowers giving promise of a treat for boys and birds as the summer advances. The trees and shrubs show a varied yielding to the season's influence. The rough, repellent Hickory has great, swollen buds ready to release the enfolded leaves. The Oaks are scarcely willing to yield at all. Half-grown, spoon-shaped leaves are out on the 
Witch-hazel, contrasting oddly with the empty cases of last year's seeds. It now bears not only young leaves, but embryo seeds from last season's blossoms, and the rough, hardened outer shells of the seeds discharged last fall. As the summer advances the nut-like seeds will develop in the shade of leaves, and after the foliage withers there will come a rich profusion of yellow blossoms. In spite of all these strange and irregular habits it responds to the inspiring impulse of the season of growth. 


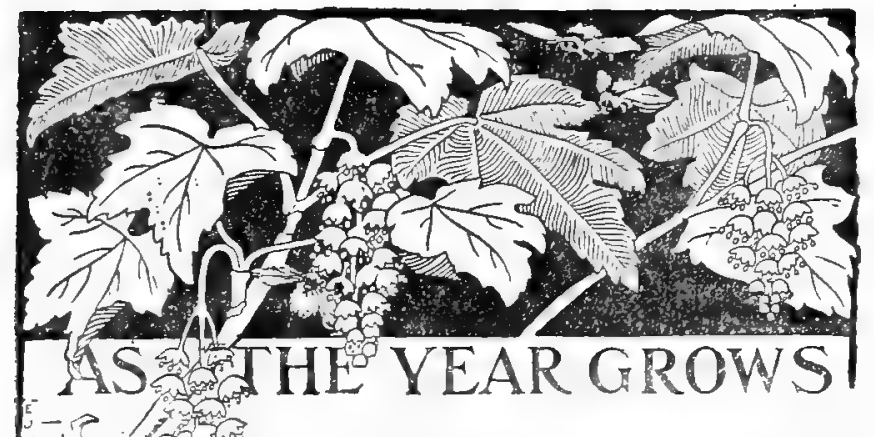

SUMmer's glow is in the air, and the leaves are unfolding and expanding with easy freedom. Cramped and confined so long in the inert winter buds, they enter into the joy of the season, and spread out, in rich, restful profusion, their many shades of tender green. The open tracery of a week ago that revealed the passing clouds or the outlines of roofs and chimneys is filled in with myriad dots of growing green that make the trees assume their characteristic outlines. The unfolding of flowers on the branches overhead prolongs the atmosphere of spring. The Sycamore Maple is now covered with clusters of blossoms, filling and rounding off its outlines so completely that it seems to be in perfect leaf. But the leaves are more backward, just unfolding their diminutive forms from the elongated scales of the buds that enclosed them with the flowers throughout the winter. These yellow-green clusters are now fulfilling their fruitful 
mission, and will be transformed into drooping and swaying bunches of winged seeds as the leaves develop. The Soft Maple and Silver Maple flowers fell several weeks ago, and the seeds are already developing. Elms flowered still earlier, and some of their seed is ready to be cast on the wind. But their flowering and seeding in the upper branches have passed unnoticed, except for the scales of the buds. strewn on the pavement. The young leaves are unfolding from the flower clusters of the Horsechestnut. The glistening, brown, thorn-like buds of the beech are elongating and giving in their changing tints a promise of coming foliage. Even the reluctant Oaks unfold their lobed and half-formed leaves to dangle their pendent flowers in the fertilising breeze, while the branches retain some clinging bunches of las year's leaves. The Basswood refuses absolutely to display a trace of the richest of all greens concealed in its dark-red buds. Among the evergreen tassels of the White Pine the flowers appear as bristling tails cf lighter green. They will fill the air and the sluggish water with their pollen, perpetuating the childish belief that sulphur comes down in thunderstorms.

Feathered visitors from the south found the trees entirely unprepared. They looked about as if they had arrived in the house-cleaning season. A pair of Robins braved the embarrassment and annoyance of a passing crowd of spectators and built their nest 


\section{AS THE YEAR GROWS}

on the still naked limb of a Horse-chestnut. Another pair chose the matted Vines around a bay window. The Yellow Warbler is already calling from the trzetops, where there is not sufficient yellow-green foliage to afford his usual concealment. But out in the suburban woods the birds have brought the summer with them. Meadow Larks sail over the fields with pendent, tremulous wings, or stand erect on the rising ground, displaying the black crescents on their yellow breasts. Woodpeckers sound their loud alarm, each in his own peculiar way. Thrushes flit silently among the lower branches. The Sparrows, that suffer through the reputation of their English. cousin, have come back. The Bluebird is already familiar. And the Brown Thrasher, the most inspiring singer of the woods, is here, proclaiming in melody the renewal of nature's perpetual youth. The boy's description of " a long-tailed, light brown Robin flying low through the bushes "fits him well. But when the inspiration of song takes hold of $h . m$ he abandons his lowly habits and mounts the highest branch of some convenient tree, pointing his bill to the sky, showing in careless abandon the spotted. markings on his white breast, and offering up the joyful spirit of the season in rich, varied, spontaneousmelody. The ecstasy of his song is irresistible. However familiar, it is always new. Sometimes he closes his bill, swells his throat, and exhales a. 
ventriloquial melody that eludes and mystifies the listener. It puts the eye and ear at variance. "It cannot be that bird, for the song comes from elsewhere." Now it is in the Pine overhead, again in the impenetrable Cedar just behind, and still again it seems to come from the surrounding atmosphere. But there sits the musical ventriloquist on the slender limb, clearly outlined against the sky. Suddenly he throws off the disguise, opens his bill and pours his song out to the sunshine, to blend with the spontaneous life of the growing woods. 


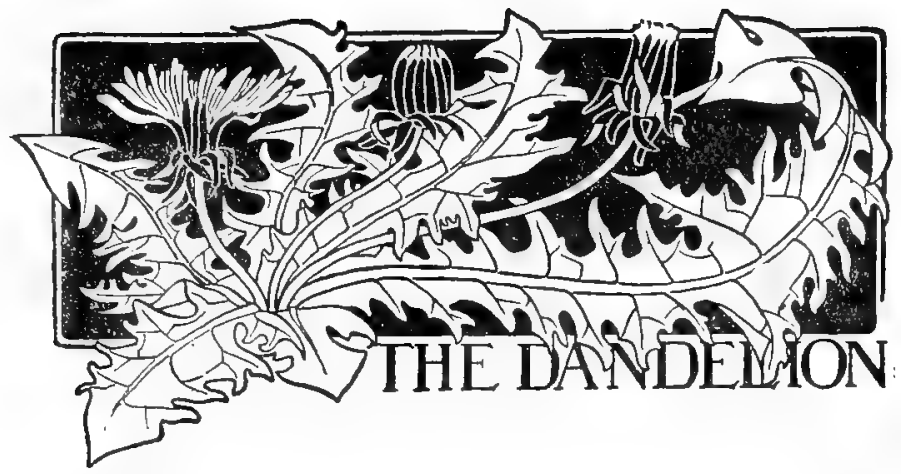

APART from its rich glowing colour, its eagerness to greet the spring, and its contented gladdening of latest autumn, the Dandelion can be loved for the enemies it has made. It is the enemy of the alldestroying grass that obtrudes in every suburban wood, relentlessly killing off the delicate wild flowers and transforming the varying labyrinth into monotonous sod. No one can watch the grass year after year slowly killing off the spring beauty, the Blood-root, the Bellwort, and other varied delicacies of the new season, without feeling a vindictive pleasure when the Dandelion comes along and elbows a conspicuous place for itself. Grass is to many an object of solicitude bordering on veneration. To a still wider circle it is a thing to keep off, and few regard it with complete indifference. To walk on a white man's grass is as great an affront as to cast your shadow on a Hindoo's food. Children are enjoined from playing upon it, and its proper 
and perfect condition is maintained with unceasing care. But along comes the iconoclastic Dandelion, takes up its abode in the most treasured spot, and glares defiance at the most solicitous attendants on the venerated herbage. It comes to avenge that hidden tragedy-the smothering of the delicate wood children in the shade of the surviving trees. Those children need the fostering care of mother nature. The mantle of leaves is a covering in winter and a nourishing support in spring. If these are gathered up and burned, the way is opened for the encroaching grass. But there would be a break in nature's perfection if there was no Dandelion to come in its aggressive strength and avenge the weak and defenceless.

The Dandelion is among the earliest flowers of spring and the latest to bloom in the fall. It does not enjoy the woods, but prefers the more strenuous life of meadows, roadsides, and lawns. It glows bright and yellow under the first touches of awakening warmth, and with the persuasion of a few days of spring it spangles the fields and lawns with brilliant points of gold. The green sward in grey morning seems lit by myriads of glowing stars. The scattered flowers expand as cheerfully in the inhospitable grass of the lawn as out among the sedges, where the dew makes the matted cobwebs visible and forms in crystal globules in the lupine leaves. The man who suffers through seeing Dandelions glowing in his 
lawn must have been made for suffering. The flower soon changes into the round, airy "seven-he-loves," and then the passing breeze or the play of children (of any age) scatters the seed on its way to new victories over the defences of the grass. The Dandelion's life is a perpetual spring. Throughout the advancing summer it expands and glows with all the intensity of the opening season. And when the leaves have withered and the grass is weakening with its own weight, when the root-leaves of next season's flowers are tracing their distinctive patterns on the ground, the brilliant rosettes of the Dandelion come out with all the rich warmth of early spring. There is a happy informality about this appearance in late autumn that makes it doubly welcome. Through the winter the root-leaves survive under the snow, an earnest of complete and perfect naturalisation, and a happy solution of the problem of perpetual life. 


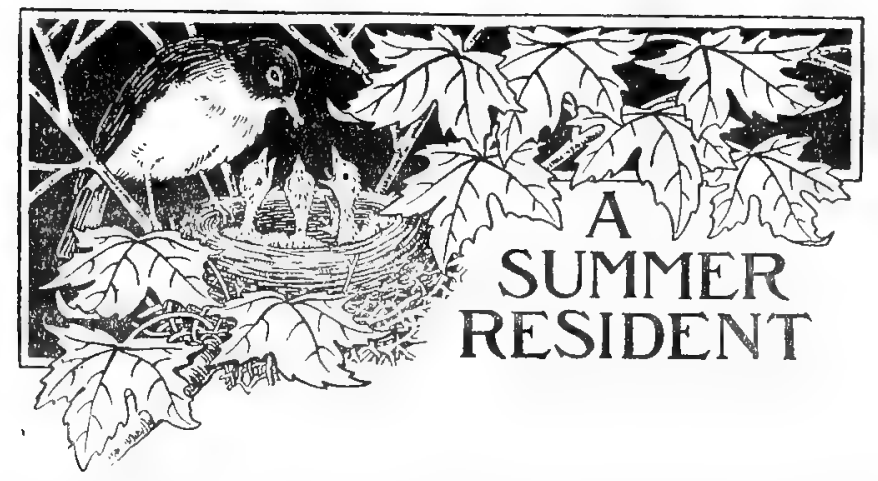

IN the lingering evening the clear, mellow song of the Robin is a refreshing reminder of early spring. For many weeks it has been missed from the meagre strains of the small band of wandering minstrels that invade the city. The Robin has not been silent. His sharp note of interrogation has been incessant. His loud alarm has been frequently sounded to announce a hasty journey under the leafy branches. He has called in many tones, announcing himself to his friends. But the melodious, romantic evening song has been hushed-silenced by the pressing cares and duties of domestic life. Now that the burdensome and importunate progeny have gone their ways with the hereditary ingratitude of nature, there is an interval of leisure and the song of evening is renewed. Robins are so familiar that imagination has no scope for endowing them with the wily, intricate virtues and vices of humanity. They are classed among the earliest of spring visitors, because a few remain 62 
with us all winter. If visited in the suburban woods they do not show the eager activity of the Snowbirds, Chickadees, and Juncoes, who wrestle incessantly with the problem of a food supply, but perch quietly and rather cheerlessly in the close shades of the Cedars, as if awaiting the return of a more kindly season. A wayfarer, looking anxiously for the swelling of winter buds on the Birches, sees one fly into a closer shade and announces the first Robin of the season. The discovery is none the less welcome that the bird has been within call throughout the year. Farther south these stragglers become more frequent, but the great flocks congregate about the Gulf of Mexico.

After the days and evenings of song that celebrate the return to their northern home they settle down assiduously to the serious purposes of life. There are no more devoted parents than the Robins. Those gaping beaks rising above the mud-thatched nest, showing the yellow tints of immaturity, seem to have unlimited capacity. Every lawn and open space is searched continuously for food. Keen senses guide them to where the venturesome worms approach the surface. There is something comical in the attitude of an anxious mother Robin with her head turned to one side, so as to bring an eye to bear directly on the ground. A rigid stare-a quick, darting blowand the attenuated worm is pulled out of its burrow. 
Then it is pounded on the ground, tied neatly in a bundle, and carried speedily to the nest to fill those gaping, yellow throats. After the greedy progeny leave the nest and learn to cry out for food the parents become still more assiduous. The biggest and fattest of the brood cry out the loudest, and as a consequence get the most food. Sometimes after one lusty-throated little gourmand has been fed into temporary quietness with half a dozen worms, a little, attenuated twin-brother, sitting unobserved in the shadow of a limb, is given an unattached worm, which he swallows in silent thankfulness. When the demands of the brood seem almost insatiable the weary and overworked parents suddenly decide to go on strike. There is an outburst of indignation on the part of the full-grown progeny. They seem to feel grievously wronged. They dart at the idling parents as if to drive them off in search of food. They chase them from place to place in vain. The elders submit to everything but a return to parental serfdom. In a day the importunate juniors realise that their support has been withdrawn and learn to get along without it. Now they are making their own way in the world, and for a time the mellow songs of early spring are renewed. Soon the cares and delights of a second brood will supplant the joys of the interval of song. 


\section{THE NIGHT-HAWK}

NIGHT-HAWKS are here. Their busy, buzzing notes come down into the dusty, noisy, electric-lighted crevices we call streets to tell us that it is really summer. The Night-hawk whistles as if he held a live bee in his bill and was calling friends to partake of the repast. It is passing strange that these birds never become thoroughly reconciled to a city, though they return and invade it again and again. Its gases and other exhalations, its swarming bipeds, its hideous wires, glaring lights, and torturing noises that drive out even nature herself, do not repel these airy visitors. They renounce the free life open before them and go down among our clean-shaven lawns, trimmed shade trees, smoking chimneys, and dusty roofs, trying by the force of example to lead us into better ways. Birds are not self-sufficient, idealistic, colonising reformers, retiring from the by-law-ridden world to live a perfect life apart. They are aggressive agitators, forcing their offensively perfect ways into the factory-made life they pity but cannot elevate. Why do they not shake the dust of the city from their wings? But so many things are strangely at variance with the universal love of ease and ownership! 
The Sparrows we have always with us. They are like ourselves. They build hideous habitations beyond their needs, and willingly endure the taints of civilisation for the sake of fighting over its few good things. The Sparrow has descended to the level of civilised man, and his power and influence amongst us is gone forever. The Swallow or Swift is a summer boarder in the city, too much inclined to adopt our ways. He brings with him the lively freshness of nature, yet after a few days' sojourning he chatters over the morning news, brushes the dust off his coat and goes about his daily affairs with the dull fidelity of his neighbours. But the Night-hawk never takes up the white man's burden. He is a missionary from the great outer world-in the city, but not of it. His name is as ill-applied as it is ill-omened, for he is not connected with the Hawks by consanguinity, sympathy, or unity of purpose. He has a grace of flight peculiarly his own, turning, wheeling, and darting hither and thither without apparent effort, or circling on easily extended pinions. The conspicuous white spot under each wing looks like a hole, and may have suggested the modern idea of ventilating yacht sails. Nature paints with a careful touch, and the great spots, bands, and patches carelessly displayed by birds in white, black, or colour are laid on the exposed webs or tips, one feather at a time, so that a plucked quill would be as irregular and meaningless as a 
fragment from a mosaic. The white spot on a Nighthawk's wing runs through feather after feather, but comes out in a strikingly regular pattern that shows when he is high in the evening air to best advantage.

This bird has a mouth that may be called ridiculous, and his little, insignificant beak is but the handle to it. When darting at insects he opens his mouth and conceals himself behind it. Truly it is a mouth to wonder at. If you undertake to open the diminutive beak you will fancy that the bird has been cut in two horizontally. The Eel Fly or Mosquito which sees that mouth approaching never lives to hum the tale. It may be that the Night-hawk is ashamed of the cavernous receptacle with which he has been endowed, for he feeds at higher levels during early evening, and does not descend till night draws her sheltering mantle about his hideous disfigurement. Late into the night, and even till daylight, he continues to blow his whistle among the chimney-tops and telephone poles, sometimes startling the electriclighted street with the giant shadows of his flapping wings; or chasing a beetle over the heads of some eager crowd, reminding them of eager pursuits other than their own.

The whistle is his chief recreation, and it often cheers the belated city straggler; but he has another game as solitary as golf, though far more animated. 
It consists in partly closing his wings, spreading his tail, and resigning himself to gravitation and fate. He comes toward the earth head-foremost with accelerating speed, but as the sluggish human mind is thinking of borrowing a spade to dig him out he catches his wings full of air and, with a loud whirring noise, turns sharply upward from the threatening roof or fence. $\mathrm{He}$ plays this game with great zest. The object is evidently to turn as close to some obstruction as possible without striking it.

When alight the Night-hawk seems a silent, surly, be-whiskered little barbarian, with none of the graceful or endearing ways displayed on the wing. On a limb he sits lengthwise, rests his tail, doubles up his insignificant legs, and poses as a knot or malformation. On a roof he looks like an indolent, overgrown swallow, twisting his head suspiciously about as if he were a stranger in the city. In her domestic establishment the mother Night-hawk impresses the needed lesson of simplicity. She does not build a nest, but merely lays her eggs on the ground. City Night-hawks nest in the suburbs, but an enterprising pair, to show their lack of prejudice, will sometimes establish quarters on a gravel roof. The Night-hawk is a messenger not of peace and good-will but of the great predatory life of the free world. He shows us that the ambitions, struggles, and desires that absorb our life and strength are but atoms in the great 
renewing and destructive conflict of nature. But the man who can pause in a city street to interpret the message of the Night-hawk from above the electric glare can never be thoroughly abandoned to civilisation. 


\section{NATURE'S BENEFICENCE}

Fellowship with nature is not denied to dwellers in the city. Though it may seem far away and lost in impossible distance, it is really crowding in on every hand. Some animals may have long since departed, the wisest being first to go. The Beaver leaves with the earliest indications of permanent human settlement, as a prudent man foreseeth the evil and hideth himself. One by one his forest friends depart, as wisdom gives them understanding, until a few degenerates like the Muskrat and the Skunk fall into habits of domestication. Birds may avoid the city, with its fumes and exhalations, as a place unclean. Still the inviting fellowship is at our doors. In every neglected field, in every swampy indentation, under every clump of Witch-hazel or Dogwood, among the seedling Oaks, Maples, and Elms, by every muddy stream not yet diverted to a culvert, and even along the open roadways, the varied colours and fantastic shapes of the wild flora show that nature's lamp still holds out to burn. It is not necessary to make a long pilgrimage to the primeval forest, nor to envy those blessed with the privilege of a private audience with the spirit of solitude in her 
own home. Almost within the street car and pavement radius, the whole growing year, from the first revival of spring life till the white coverlet is spread over the sleeping earth, may be enlivened by the beauty in which the great world renews her youth. The flowers remain, and, while the boldest bedeck the fields and roadsides, the timid look eagerly for recognition from every secluded nook and shady corner. They seem to find protection in the shadow of the city, for while the thrifty farmer prides himself on the devastation of every square foot of his broad acres, there is a respite in the neglected suburbs, and the mystery of growth is spontaneously unfolded.

A suburban ramble will always disclose, in the margin of forest life which seems to have escaped between the builder on the one side and the farmer on the other, enticing little spots where the proximity of a great aggregation of struggling humanity can be forgotten, and a few hours of real life can be enjoyed in peace. In these places the wild flowers seem to call the stroller away from the cities and summer resorts. They have new attractions to present daily. The delicate blossoms of early spring, the Hepaticas and Dog-tooth Violets, the Squirrel-corn, Blood-root, Spring-beauty, and that whole train of early debutantes have disappeared, but a more vigorous and more aggressively handsome company have taken 
their places. The Downy Convolvulus, with its great, delicate white bell and sturdily-leafed stalk is now in flower. The yellow blossoms of the Rock Rose, the rich, blue lobes of the Gentians, the blue stars of the Chicory, the delicate pink flowers and pretty foliage of the Dogbane, the imposing hues of the Wild Orange Lily, the tall, pink-purple spires of the Great Willow Herb, are now among the common offerings of suburban fields, while a score of more retiring flowers, are waiting quietly in outof-the-way nooks to greet their inquiring friends. The Golden-rod is already showing its distinctive hue, and the Loose-strife, intricately handsome in foliage and flower, is marking the courses of the rushchoked streams. The Dogwoods are shedding their white masses of large-petalled flowers, and the yellow spangles are disappearing from the Bush Honeysuckles. The rewards of an hour in the suburbs are infinite, and the invitation is for ever open. 


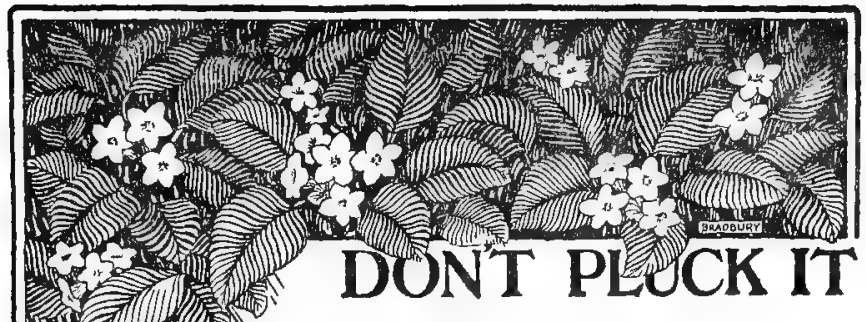

THIS is the admonition that should be carried abroad on every suburban ramble. The healthy and growing interest in the great out-of-doors cannot be contemplated without a shudder at the destruction of plant life it seems to entail. A childish delight in the brilliant or delicate tints of a flower, in its enticing perfume, and its spirit of renewing life, prompts the ready little hand to reach and pluck. There is no more delightfu sight than a child with cheeks and eyes aglow and hands filled with the rich and dainty treasures gathered from the deep shades of the woods. But the speedily wilted and faded masses must inspire a feeling of regret, and perhaps of pity, even in the childish mind, for the fruitless destruction that has been wrought. Wild flowers unresistingly wither and die when plucked and brought out into the bright sunshine, a most appealing protest against their destruction. Their place is in the shades of wooded hillsides, along damp, swampy ravines, or nestling among ungainly roots, where the trunks of an older 
generation have settled into long mounds of moss and lichens. There the floral treasures are to be found, and there they should be left to live out their lives, emblematic of the joy that lingers where all seems shadowy and dark.

There are flowers that can fight their way among the grasses of the hills and fields, and give a happy and defiant invitation to all who seek them. The oxeye Daisies of summer may be gathered in armfuls. The Cone Flower, too, seems to thrive in spite of its rich attractiveness. The Asters of advancing summer and the Golden-rods of autumn are also of the composites that thrive in spite of inconsiderate collecting. Jo Pie Weed, tall and vigorous, displays its purple crown of flowers and four-leaved whirls of green where marsh and land vegetation meet. It perpetuates the name and fame of an Indian medicine man. But there are so many flowers that suffer and are threatened with local extermination that their friends are warranted in appealing to the public to spare them. The beautiful blue of the Fringed Gentian is seen less frequently than heretofore. It is an annual and unless its flowers are allowed to fill their mission and produce seed it cannot survive. The deeper ultramarine and lighter shades of the Lobelia are also growing more scarce by the choked and sluggish streams, and the Cardinal Lobelia, the brightest of all the sisterhood of flowers, 
has been driven out into the wilderness. One of the earliest debutantes of spring, the Trailing Arbutus, is disappearing. Its early arrival, its rich perfume, and seductive habit of nestling and hiding among last year's leaves give it an irresistible charm. The trailing stem has but a weak hold on the ground, and as it is extremely tough it is often carelessly torn up. All who must pluck the flower should be careful to cut off as little of the stem as can satisfy them, and not tear up the tender roots.

The Hepatica, with its succeeding generations of flowers and leaves, is surviving the hands of the spoilers. The Blood-root dies so soon that it is frequently overlooked, and the Spring Beauty withers so helplessly in protest that there is but little temptation to pluck its spray of delicate pink. A weary stroller with a bunch of wilted Trilliums is a lamentable spectacle. The drooping of their white or painted petals is a silent appeal that should be heeded. Leave them where they grow. The Harebell, with its frail and delicate cups of blue, seems able to defy the encroaching grass and to flower through the whole summer ; but it should not be forced to fight the encroachment of man as well. Many of our wild Orchids are blessed with a fatal beauty. The Showy Orchis is growing rare, and the Fringed Orchis still rarer. The Northern Calypso, with a delicacy of form and tint that always eludes the artist, is, indeed, a 
rarity, almost as much so as the flower-lover who can find it and leave it unmolested. The Yellow Lady's Slipper is still found, but so rare as to appeal, too often in vain, for mercy. The Showy and the Pink Lady's Slippers are comparatively safe away in the sphagnum swamps, as are the Arethusa and the Snake's Mouth, but even there they are now pursued with threatening persistency. The more familiar the woods and flowers, the less desire is there to profane the treasures by bringing them into the uncongenial atmosphere of the city. Let all lovers of flowers learn the generous selfishness of renunciation. 


\section{A RECORD OF TIME}

ON the bank of a derelict river, within the city limits, is a mine of interesting information. It was not excavated originally for that purpose, neither is it now worked for any such product. The face of the towering hill has been cut away, and the cavern of dizzy depth and impressive extent scooped out, in gathering material to make brick for the cave-dwellers of the city. But the diggers have unearthed a record that lets in a flood of light on the history of this continent. Byron halted in awe when treading on an empire's dust. But empires are merely the momentary lights and shadows across the path of worldprogress laid bare in this excavation. The story begins to grow interesting where the cutting reaches the Hudson River rock, which bears the imprint of the varied transitions of animal life in its lower forms. Time has effected many transformations, but the casts of the shells are plain and distinct where the yielding mud has been changed to imperishable stone. There is the track of a slug-shaped creature that moved by corrugating his body and using the ridges as feet. The trail where he hurried across the mud has escaped obliteration by the rain, and now the firm 
rock bears testimony that he was here and lived his life and fought the ceaseless fight for existence.

Then the record tells of cold too intense for animal or vegetable life. For ages a continent of ice, seemingly immovable but for ever moving, ground the rugged fragments of rock into symmetrical boulders. These are imbedded in hard clay, the accumulation of a long era of glacial action. That the continent of ice moved is shown by the worn and pulverised rocks as well as by the continuous motion of the glacial ice still remaining elsewhere. That it yielded to a warmer era is shown by the abundance of animal and vegetable remains in the supervening gravel and sand. Here the shells are still preserved, and the remains of some fifty species have been collected. Many are remarkably perfect.

The great majority of these species are now extinct, but some of the Clams still survive, an evidence of the limit of subsequent destruction. The climate was milder than any that has been experienced in this region during the present geological era. The Osage Orange and other trees now indigenous to the Mississippi and Ohio valleys are found in abundance. A good-sized tree-trunk taken out was cut up and used by a cabinetmaker, the few hundred thousand years it had lain there under water, ice, and dry earth, having served to improve rather than injure it. The discovery of a Fish's head was a new revela- 


\section{A RECORD OF TIME}

tion, for it showed that the vertebrates lived in this warm era between the ages of ice. The treasure was sent to Washington for identification, but was unfortunately lost. The broken story was resumed by the discovery of part of an Elk's antler, showing that not only the lower vertebrates but land mammals lived in this region between the glacial periods.

This scene of fertility and active animal life is covered up with another immense bed of boulder clay, revealing the slow intensity of another accumulated continent of ice. Again the fragments of rock are worn round and smooth, and imbedded in the clay-the slow deposit of ages. But this second continent of ice obeyed the perpetual law of change, and above the bed of boulder clay that records its existence are the changing deposits and the waterwashed sand and gravel of the bottom of the lake that covered the land where this city now stands. Again come the evidences of marine life, shells and other remains being modern and easily identified. Contemplating that record of inconceivable time, the transient growth of Oak, Pine, and Birch on the top of the hill seems as presumptuous as man's usurping institutions. But a few years-few as time is recorded in that cavernous pit and excavated hill-and the continent may sleep again in the long oblivion of a glacial era. 
80

\section{A DAY IN JUNE}

IT seems in all-including motherly kindness that the trees are spreading their great, umbrageous leaves over the hot, tired earth. The brooding shade is ever cool and inviting. There is a soothing quietness in it that lulls the most restless into placid waking sleep and day dreams. The inspiriting panorama of spring has passed. The transient feathered visitors who lent the charm of melody to the joyful season have departed for their northern homes. The happy excitement of their visit is over, and they have left the calmness of a pleasant memory and the satisfying hope of renewals. Those who have come to spend the summer have quietly settled down to the serious affairs of life. Many do not sing as in the earlier days. Their joy has not departed, but has found new fields of expression. It is manifested in the lively happiness of domestic life. There is a fuller joy beaming in the bright eye of the Robin, hastening with a battered worm to its importunate fledgling, than in the sweetest melody that filled the early dusk of even ngs in spring. The feathered bipeds find a joy in all the shifting scenes of life. A few continue their song through the sultry season, and seem to 
have a double portion of the delights of existence. The song of the Veery, the churning, dashing, bursting melody that reveals a spontaneous gladness, is still heard among the leafy shades. Much has been said and written of the Veery's song, but only to reveal the poverty of words in its description. It is a part of the gladness of nature, to be absorbed and enjoyed in its own spirit. Other songsters, with their own peculiar charms, are still carrying the spirit of spring on into summer. Perhaps that is the mission of all songsters. The Yellow Warbler still sings as happily as in the days of his courtship, and his note has a distinctness lent by the silence of so many of his feathered relatives. The Oven Bird's penetrating repetitions come along under the branches, and the Brown Thrasher still sings to the sun from a lofty perch. There is just enough melody through the shady branches to make their quietness more somnolent.

A glimpse of yellow and white shows where a Flicker curves and undulates through the open spaces to the broken shaft of an old, dead Willow. The brown-grey back, almost invisible against the bark, disappears, and after a long, patient wait, with no sign of the alert head on the other side, the temptation becomes irresistible. There is a nest. Just below the broken limb a hole has been picked in the decaying wood, but it is a false one. One would like to think it 
was made to deceive or distract attention, but chilling, disagreeable fact suggests that the wood was found too hard. The successful excavation is higher up, and there she is already, alarmed at the stealthy approach, looking down with bright, round, startled eyes at the great, threatening intruder. A moment, and the staring spell is broken-she glides boldly out and wings her irregular course beyond the sheltering Maples in the crowding foreground. A slender arm can explore the rough tunnel in the wood, and down at the bottom is a little, solitary egg. The tiny object of her solicitude is brought forth to the light. It is pure white-so pure and translucent in the sun's rays that the yelk within gives it an elusive yellow tint, but in the shade its clear whiteness returns. With a care that even the startled bird could not surpass it is replaced, and with apologies unexpressed the intruders retire. Again the passing flash of yellow and white shows how anxiously and carefully she has been watching. She enters eagerly, and, after an anxious half-minute, comes forth again, happily satisfied in the safety of her treasure.

The Indigo Bunting is among the pleasant summer songsters, but it is only by an accidental meeting in a shady spot that his handsome colour can be appreciated. In the warmth of summer even little Chippie, with his chattering trill, has a place among the 


\section{A DAY IN JUNE}

favourites. The industry of these little friends, brightened by an occasional song, blends with the atmosphere of life and growth pervading the season of fruition, an atmosphere that steals upon the senses more seductive and inspiring than the subtle fumes and vapours distilled from the drugs of the somnolent East. 


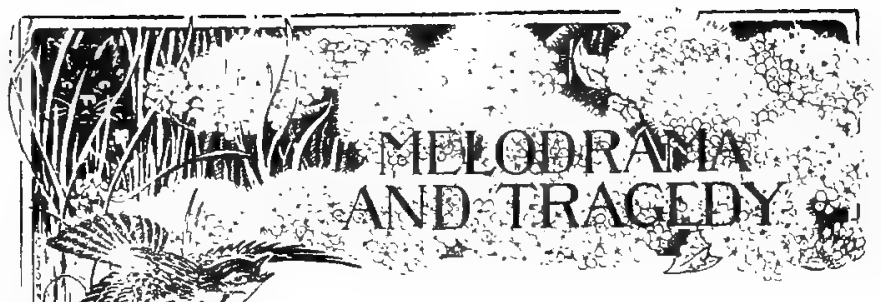

A SUDDEN fluttering almost under foot, and slow, reluctant flight close to the ground revealed the location of a Song Sparrow's nest. In open and unwarranted confidence it was placed on the ground, though built with care and compactly rounded. The five eggs were carefully and regularly placed with their small ends downward. They were pale, almost white, with the rich brown spots crowding and clustering on the larger ends as if they were freckled by exposure to the sun. It seemed a tempting of the fates thus to risk the depredations of thoughtless boys and vagrant cats. Sometimes the Song Sparrow builds near the ground in a bush, but this one had risked the level surface. Three days later good fortune and assiduous devotion to parental duties had combined to reward the mother with three nestlings, their big, round eyes still unopened, but their gaping throats revealing a misplaced confidence in the bounty of intruders. On the following day there was a genuine surprise. Crowding the three nestlings and the two unhatched eggs was a half-fledged intruder from another family. How did it get there? 84 
Its naked wings and weak, tender feet showed that it could not have wriggled or fluttered along from some other nest. No boys were in the neighbourhood. The mysterious intruder was not an English Sparrow, for he had the more slender bill of his foster parents, though not sufficiently fledged for identification.

He might afford an imaginative naturalist material for a pathetic story of a faithless Song Sparrow who had deserted his home and family and was pursued by them to his new surroundings. The possibilities of domestic complications in such a situation are infinite. Triumph, revenge, retribution, and disgrace could play their several parts. The romantic naturalist could picture the warning fate that follows upon the breaking of promises and the neglect of duties, but the ordinary observer can merely watch and wait. The strangely mixed family must have been a serious burden to the little mother, but did not seem to occasion any distress or annoyance. The next visit showed that tragedy had usurped the sphere of melodrama. The young stranger's life in his new home had been cut short, evidently by a predatory cat, and one of the little nestlings was also missing. There was no evidence that the mother had rejected her foster fledgling. The family without the mysterious stranger and depleted was far less interesting, still its fortunes were watched with sympathetic diligence. But the cat fulfilled its 
proverbial predilection by coming back. Next day the nest was empty, and two somewhat uneasy Song Sparrows inan adjacent Willow seemed to be considering ways and means for a new domestic venture. The ways of feathered life are strange and often mysterious. With ample precautions against the blending of observation and imagination much may be discovered and disclosed to strengthen human sympathetic interest. The unfolding of a strange family history may be cut short by the depredations of a feline enemy. The little glimpse of a life under peculiar circumstances, mysterious in origin and uncertain in its untimely end, seems a reflection of the calls that come down out of the night from passing strangers as they follow their mysterious courses from zone to zone. 


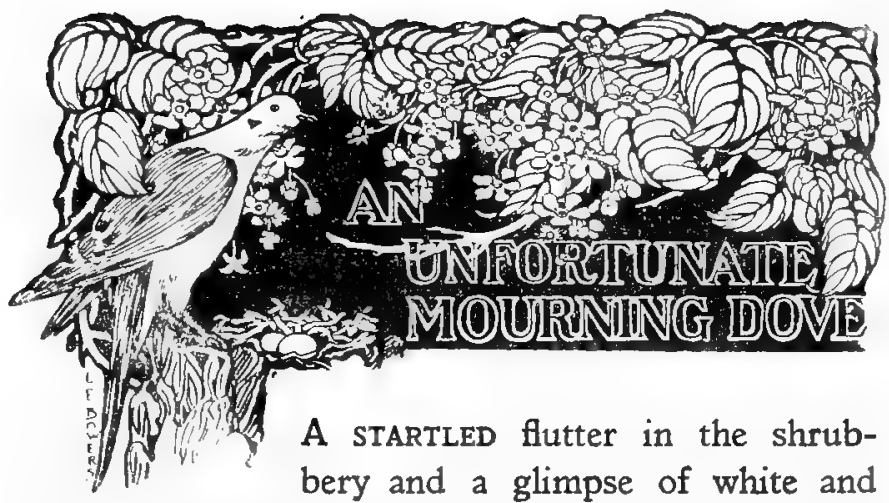

neutral colours curving and disappearing among the bushes revealed the secret of a Mourning Dove. With maternal instinct she followed a low and concealed course, but her rustling strokes declared her identity. They made a marked contrast with the silent flight of a recently disturbed WhipPoor-Will. The trees had been cleared away three years before, and the second growth rising at will among the stumps and struggling for supremacy with a vagrant entanglement of Raspberry bushes made an ideal nesting-place. A rambling, sluggish depression held sufficient weed-clogged water to cover the mossy roots and leave an opening where the Muskrats swam and waded by turns or surveyed an intruder with unfriendly looks before disappearing for their submerged tunnels. On the higher ground the few stumps that had not been curtained by the bushes made comfortable resting places for the lazy Woodchucks basking in the sun. Squirrels chirred 
and clucked from easily concealed perches, and Jays called harshly from the surviving wood lot close by. The nesting-place was menaced by other enemies, for crows called and circled about where the Pines rose above the crowding Elms, Maples, and Beeches.

The clump of shrubbery where the Dove took flight was the second growth from a much older stump, partly concealed, naked of bark, and rapidly softening and decaying. In the mossy centre a seedling Elm had taken parasitic root, and close beside it in a slight depression lay the twin white eggs. There was no attempt at concealment, and from one direction they could be seen plainly at a distance of twenty feet. It seemed strange that these tempting eggs should be thus freely exposed when Squirrels, Jays, and Crows, the three most inveterate nest robbers, were noisily active all about. There was only a bare apology for a nest. A few fine twigs and roots, all dead and dry, had been laid promiscuously across the slight hollow and had been settled down by the pressure of the bird's body, affording merely a resting place where the eggs would not roll. It seemed the tempting of fate to leave them thus conspicuously exposed, but it was impossible to aid their natural guardian in protecting them.

Next morning the knowledge gained permitted a more stealthy approach from a point where the open bushes afforded a view of the sitting Dove, but she 
had become more cautious and timid. The sudden flutter and curving rise showed that a familiar view would not be tolerated. This strange mother seemed more anxious about her own safety than the protection of her expected nestlings. On the third morning, with still greater stealth, the sheltered stump was approached, but peering, halting, and advancing revealed the discouraging truth that the eggs were gone. A Dove, probably the bereaved mother, flew past and beyond the adjacent woods, showing no inclination to return to the scene of her domestic tragedy. As there was no collector in the neighbourhood, the marauder was probably a Squirrel, although the Jays and Crows were not free from suspicion. The Mourning Dove, whose soft, cooing tones always attract attention, is sometimes mistaken for the doubtless extinct Wild Pigeon. Its long pointed tail, showing white when expanded, is a conspicuous mark. Its slaty brown and buff are relieved by the neck adornment of iridescent green, and there is a dark spot below either ear. This careless nesting habit makes it a prey to many enemies, but is not so jeopardising as the gregarious domestic life that made the Wild Pigeon an easy victim of the most relentless devourer. 


\section{THE LIFE OF A MOTH}

IF one manifestation of nature's ways can be more marvellous than another the chief distinction must be given to the transformations of the insect world. The beautiful Promethea Moth emerging from a grey silken cocoon that has been lying inert on the desk for weeks cannot fail to appeal to the spirit of wonder. A ripping, cutting sound is the first indication of awakening life, as the knives with which the shoulders of the coming insect are armed are used to make a passage through the hard, tough covering. Soon the head, with its feathery antennx, comes forth, and the queer, misshapen, elongated insect vigorously extricates itself from its shell. It misses the Lilac bush, where, in its previous incarnation, it went to sleep last fall. It runs eagerly about hunting for some point of suspension, for without the aid of gravitation those bulbs on its shoulders would never develop into perfect wings. A book leaning against a shelf affords the needed perch, and there the process of transformation goes on with strange celerity. The attenuated body begins to enlarge and shorten and to take on its normal texture and rich colours. One joint after another from the thorax rounds out into shape. 


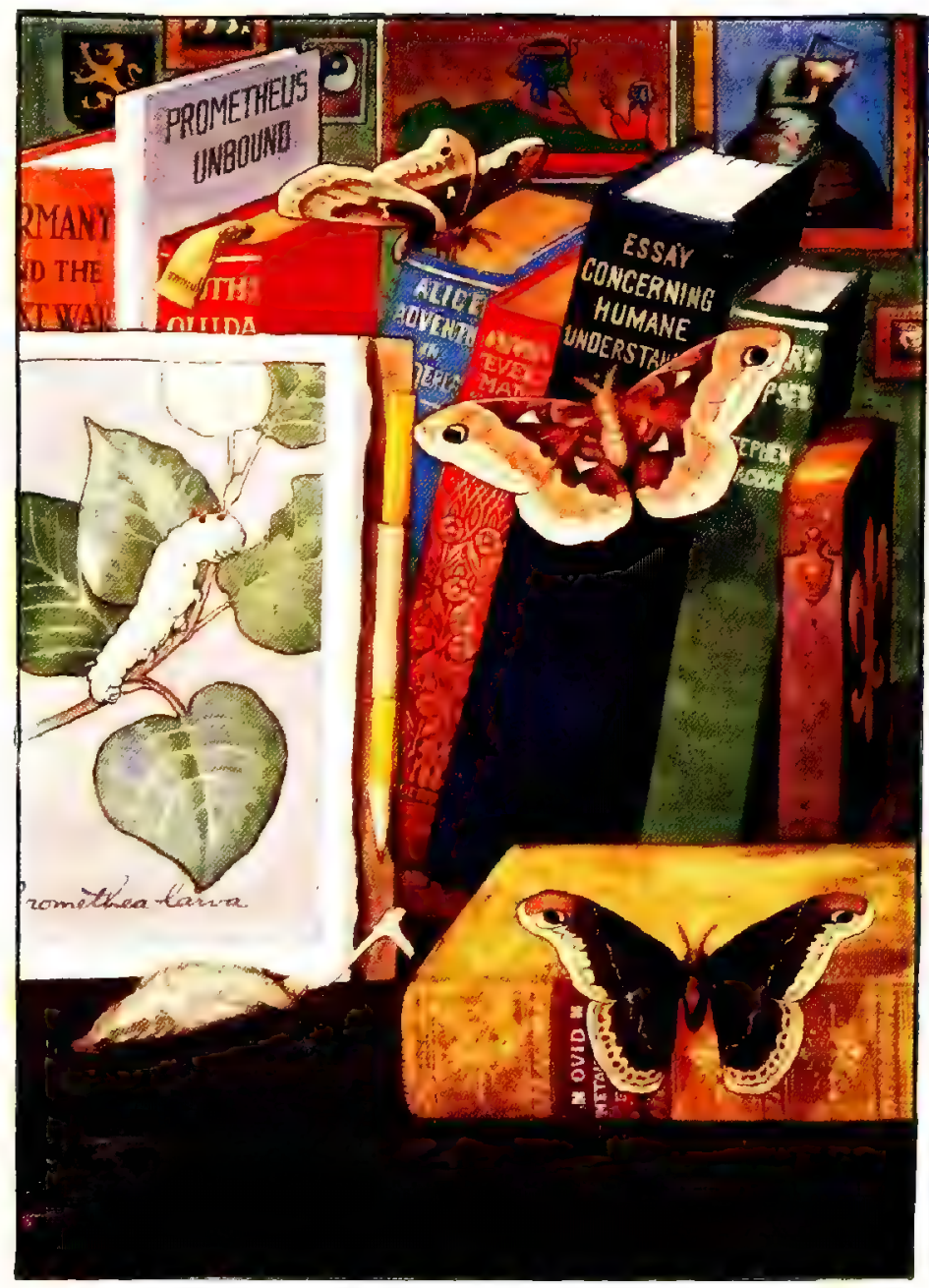

PвоMетHEA MrTh 

While this process is going on the bulbs on the shoulders are forming into wings. The change commences near the body, and the pulpy mass is gradually transformed into beautifully marked, velvety wings. The process continues until the pulp is but a marginal band on the wings, but this is still capable of considerable extension before the thin membranes are completed. Then the Promethea poses and surveys a new and strange world, while the newly-formed wings, four inches across, are moved gently and timidly as if to make sure of their existence.

This large and beautiful Moth is the mature female development of the great, thick Worm that crawled about last summer and nibbled the leaves of the Lilac. Then it feasted leisurely, a crawling Worm. Now it is beautifully equipped for flight, but can no longer eat, and its life mission will be fulfilled perhaps within the coming night. This Moth can scarcely be regarded as the Worm transformed, for she excretes in fluid form all the vital, internal organs of her larval existence. Before lapsing into the inert pupa state she casts off, with her outer covering, her legs and all external organs, including even her head. There is a deepening of the mystery of identity in this casting off of all the parts of a previous existence. When the Promethea larva decided to retire for the winter, she selected a con- 
venient Lilac leaf and began by winding silk industriously around the twig where it grew. From this foundation she proceeded down the stem of the leaf, winding around and about and thus spinning a tenacious silk cord. On reaching the leaf she began to fold it about herself, drawing it in gradually at various points until it became a closely enfolding overcoat. Within this covering the exuded thread of silk was wound and wound until it formed a complete and strong cocoon cemented securely to the enfolding leaf. Thus protected the inert chrysalis slept through the winter, oblivious to frost, snow, and rain. Some day we shall discover a means of dissolving the gum with which our Canadian Moths cement the silk of their cocoons, and then we shall have the raw material for a silk industry.

With the approach of evening the Promethea begins to manifest great activity, trembling and pulsating with abundant life. Her beauty is not destined to perish unappreciated, for the closing darkness brings several suitors to the open window. The males are darker and of different form, and live but to fulfil their reproductive mission. Away goes the beautiful lady with dizzy, irregular flight, perhaps to fall a victim to the Night-hawk calling out of the darkness overhead, but more likely to sparingly distribute her eggs on the Lilac, Witch-hazel, and Choke-cherry trees for many miles along her noc- 


\section{THE LIFE OF A MOTH}

turnal course. That purpose achieved, her transient life goes out. But every egg that escapes the parasitic insects and nimble warblers gleaming among the leaves hatches out a perfect larva, to complete the same strange metamorphosis. 


\section{4}

\section{POPULAR TYRANTS}

THE season of woodland song has merged imperceptibly into the drowsy fullness of summer. The varied carols that enlivened the woods in the time of nature's renewing are silenced. Occasionally a Yellow Warbler may raise a cheerful call, as if determined to make his life a perpetual spring. The Robin in the evening may forget the passing of the seasons and break forth in varied melodies. These are but interludes in the silence, otherwise unbroken, save by the agitated chirp of an anxious parent alarmed at the threatened invasion of her nest, or the importunate calls of selfish fledglings demanding more food from tired but industrious providers. But the season of fruition has its own peculiar charm, for it brings out the varied characteristics of all our summer residents.

Fly-catchers are among the most interesting and individually distinctive of all the visitors who find our summer shade congenial. Their marked family characteristics do not efface the striking personality of the various members, and each sustains his dignity in his own peculiar way. They have been called tyrants and will never escape from the name, 


\section{POPULAR TYRANTS}

although their many friends protest that it is undeserved. The Kingbird is responsible for both the name and the reputation it carries, and he has won it by his fierce, spectacular, and vindictive attacks on that dull, unimaginative nest-robber, the Crow. A Kingbird pursuing and torturing the big black marauder, keeping close to his side and almost under his wing, darting at him with savage persistence, and driving him here and there among the trees, is one of the most exciting scenes in the whole summer panorama. "As the crow flies," becomes a deceptive measurement, for he turns, twists, whirls, and flaps hither and thither in wild alarm, struggling to get away from the pursuing tyrant. Other birds dart at the black Ishmaelite and drive him off, but the Kingbird gives him no quarter.

When the tyrant returns to his perch on a conspicuous bough in the bright sunshine, sitting erect and dignified, as become his family and position, he might naturally be regarded as one of the most kindly and tolerant of birds. His dark coat and white vest make a conspicuous contrast; his tail is tipped with white, and his black, erect crest conceals some bright red that is never seen except when the outer feathers are parted with the fingers. He sits upright, occasionally turning his head from side to side, his bright black eye- Away he darts, interrupting a spectator's description, leaving the perch shaking 
behind him, and the snap of his bill can be distinctly heard as it closes on an unsuspecting Eel Fly. See how happily he completes the circle, and how leisurely he returns to his conspicuous perch!

The Great Crested Fiy-catcher is larger than the Kingbird and of lighter colouring, showing, when hurrying through the naked branches of the tallest trees in spring, a blending of light brown, grey, and pale yellow. His crest is a conspicuous mark, and his whistled call, repeated at intervals, is loud and penetrating. It suggests a Robin trying his voice. Now he is silent. It is a rare experience to see him in the summer woods. The Olive-sided Fly-catcher is similarly decked in summer tints, but is smaller than the Kingbird and more retiring in disposition.

Every one knows our little Phœbe, the pet of the family. Her colours are of the plainest, but she chooses the naked limbs in orchards and shade trees, and the most conspictous posts by the roadside, her free confidence winning many friends. The Wood Pee-wee prefers more secluded places, and can be known by her pale yellow breast and high, thin, plaintive notes. The Chebec is the smallest member of the family, and she pronounces her name so distinctly that she seems vain of it. Her pale breast and white wing bars are points of distinction. She sustains the family dignity in her upright poise and conspicuous crest, and is true to its traditions in her 


\section{POPULAR TYRANTS}

eager and certain pursuit of passing insects. Tyrants are welcome when they serve our purpose, and so this well-poised family are praised most highly because they prey upon the insects which have escaped our fumes and poisons in their larval stage of development. 


\section{8}

\section{SPOTTED SANDPIPERS}

IN spite of the invading sand pumps, the dusty procession of scavenger carts, and the drifting cans and kegs that make their way over the weedy water, Spotted Sandpipers continue to make their homes along the sandy barricade of the marsh. It is their ancient habitation, and they simply ignore the impertinence of the other bipeds who have invaded it in a swarming half million. There must be a fascination in the sand-girt marsh, for the shorewaders never fail to rest for a few days on their long journey to arctic or inland summer homes. Throughout the entire season vagrant Kildeer, Black-hearts, and Stints are coming and going. But the Spotted Sandpiper comes to stay and make his home. Among the rounded and water-washed pebbles of the shore he would often be invisible but for the perpetual tilting motion of his body. Whether feeding in the soft mud or posing on a sandy ridge outlined against the mingling and uneasy waves his restless energy keeps up the same untiring motion. His body seems to partake of the ceaseless impulse that urges the water, even when the air is still, to rise and fall against every confining margin. These birds give a touch of 
animation to every shore in the continent from the Gulf to the Arctic Sea. They are at home by the great lakes and by the drying ponds and failing streams, also along the coasts, by mountain lakes, forest-bordered rivers, and the sloughs of the open prairie. They seem in fancy to have become imbued with the moving restlessness of the untiring attack of the water upon the land. When they fly in a short detour their quivering wings seem divided into four by long white marks across the feathers. Although they indulge in long night flights from the perpetual summer of the Isthmus, they locate freely from the Gulf to the northern limit of their range. Like all the feathered migrants, they have long known the sustaining power of the evening and the night air, and human inventors with their awkward imitations have become equally wise. Night flights have given an air of mystery to bird migrations, but there has been a gradual revelation of their secrets.

On the sandbar Spotted Sandpipers have nested with familiar confidence in spite of the city's aggression. A startled noisy dash, when fear overcomes the maternal instinct, reveals the cause of alarm and anxiety - a nest hollowed in the sand and carelessly lined with weeds and grasses. Four unnaturally large and dusky eggs, blotched with brown, lie snugly with their small ends together, the pride of the distressed mother, now running appeal- 
ingly over the sand and turning back frequently with frightened stare. Continued nesting from the end of May to the first week of July suggests the possibility of a second brood. As soon as the young are hatched they leave the nest and run over the sand, little helpless balls of grey down. But their wing quills grow rapidly, and soon the careful mother is free for her southward journey. When night makes the more subdued sounds of the marsh audible the Sora Rail cackles distinctly in the dense rushes, and the whistle of the invisible Night-hawk reveals the active life of the upper air. A subduing pause is broken by the close, sharp, repeated note of the Spotted Sandpiper, intolerant of intrusion even on the moonlit reaches of the sandy shore. 


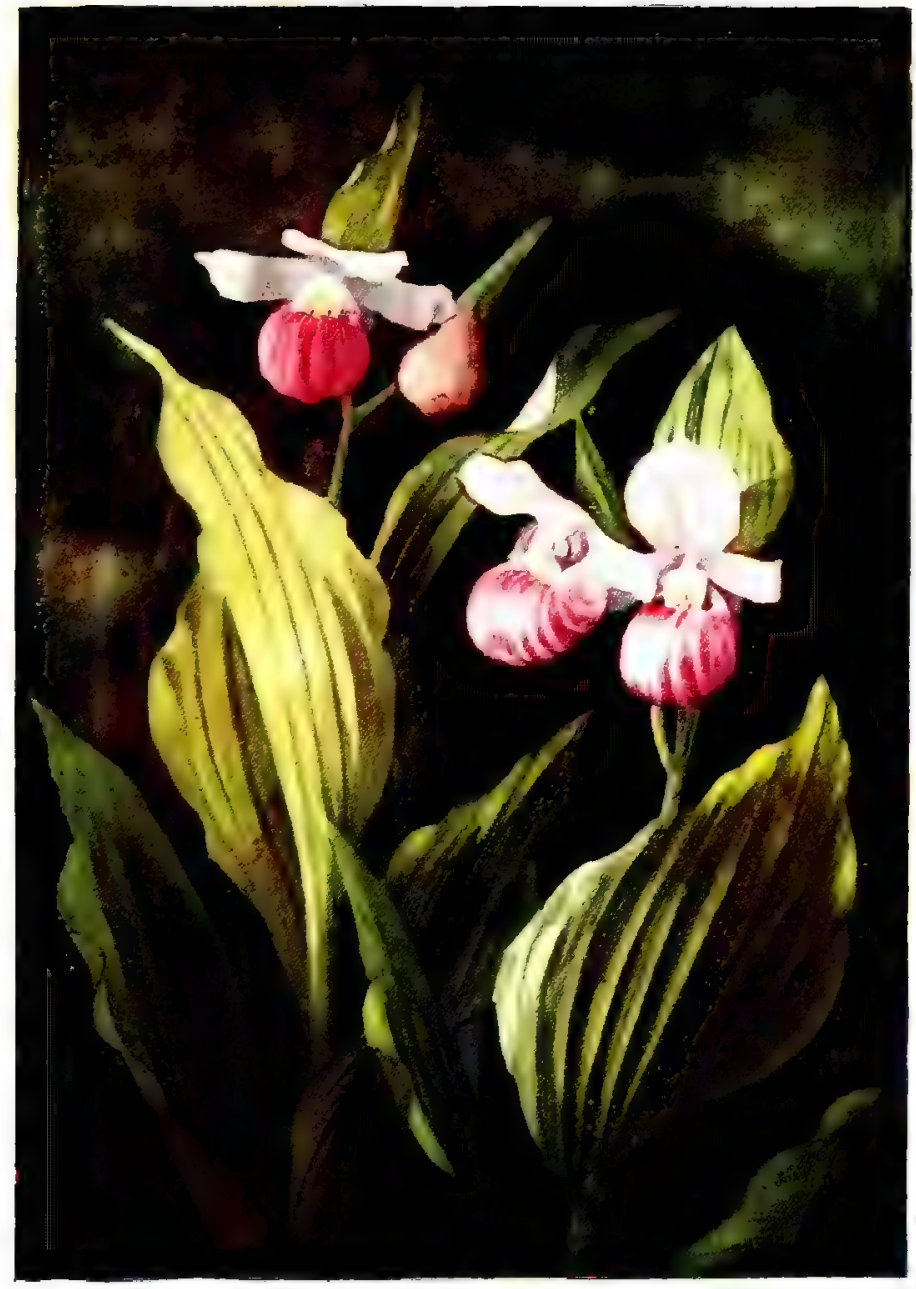

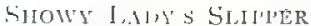





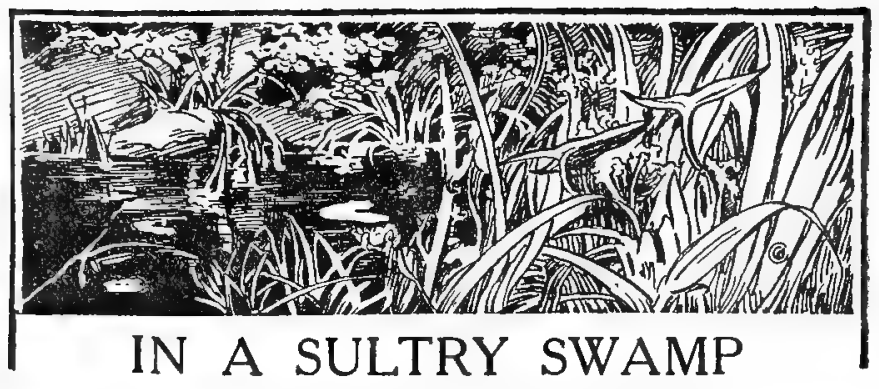

THE growing, living odour of matted Sphagnum moss makes even the sultry moisture of the entangled swamp an irresistible attraction. That perpetually damp and spongy moss growing up in tinted, spreading domes and hollows, while dying at the roots, slowly converting ancient ponds into peat bogs and nourishing a heterogeneous gathering of seedlings into elbowing, struggling trees, seems a perpetual fountain of vegetable life. The charm of renewal that makes the call of spring irresistible where the early flowers look up for recognition seems to last throughout the growing year where this yielding moss continues its endless transformation of death into life. The seedlings nursed by its moisture and fed by its continuous fertilising growth interlace their roots below the changing surface, and mingle their aggressive branches in the struggle upward toward the excluded light. The bristling Tamarac is a favourite, and seems to delight in obstructing and closing every possible avenue. The conical 
Cedars spread their closely layered branches down to the surface of the Moss, and the Spruces crowd so close that their lower branches shrivel to brittle, noisy obstructions. Poplars still struggle against the slower and more persistent aggression of the Evergreens, and sometimes a Silver Birch can find a breathing space. The feathered Hemlock, with large trunk and sturdy roots, rises above the jostling crowd toward the needed sunlight, its green sprays decorated with the small, brown cones of the past year. Near the borders the Alders and Witch-hazels quietly seek admission. The moss that encroached upon the ancient pond and gave the trees a foothold is still youthfully ready to receive them when they have lived their allotted time. It climbs over the dead and decaying trunks as it covers and nourishes the living roots, and some trees that once reached up successfully above their fellows toward the coveted sunlight are now merely long, irregular mounds of Sphagnum.

Birds selfishly enjoy the seclusion provided by the almost impenetrable shrubbery. The Maryland Yellow-throat sings from a close but invisible perch until his audacious curiosity can no longer be denied. The Black and White Warbler, always on the move, is indifferent toward an invader, and scarcely halts long enough to sound his linked repeated notes. The noisy Crows scold uneasily, but are unwilling to 
alight while they cannot see what peculiar creature is moving through the dense underbush. The Veery and Song Sparrow blend their familiar notes. The attractive seclusion must tempt these little homemakers, but there is no immunity from their natural dangers. The harsh Jay flies above the trees and sends his threatening shadow through the interlaced branches, warning the inhabitants of the menace of a nest-robber. The Catbird in the lower branches varies the sweetest gurgling melody with the threatening call that has given him so peculiar a name, and the Brown Thrasher, a rival in song, sings from the pointed top of a Cedar.

The usual marsh vegetation is enriched by flowers that only the Sphagnum can sustain. The Sun-dew lays down its leaves like open hands ready to clasp and hold any unwary fly, and there is abundance of insect life for its carnivorous propensities. The richest treasure of the Sphagnum swamp is the Showy Lady's Slipper, the most beautiful of our wild Orchids. Deep in the secluded and protected recesses, where stooping, climbing, and straining overcome the barriers of interlaced branches, these flowers hide the beauty that threatens their destruction. Their sturdy, leafy stems bear large, rich moccasins, waxy white with dainty markings of pink. This is a beauty of nature that no cultivation could improve, and when discovered repays the 


\section{IO4 IN A SULTRY SWAMP}

sustained effort of a day of search where nature struggles to repel invaders. Only the ardent lover of the Sphagnum swamp and its treasures can appreciate to the full this abundant fruition of a year's expectancy. 


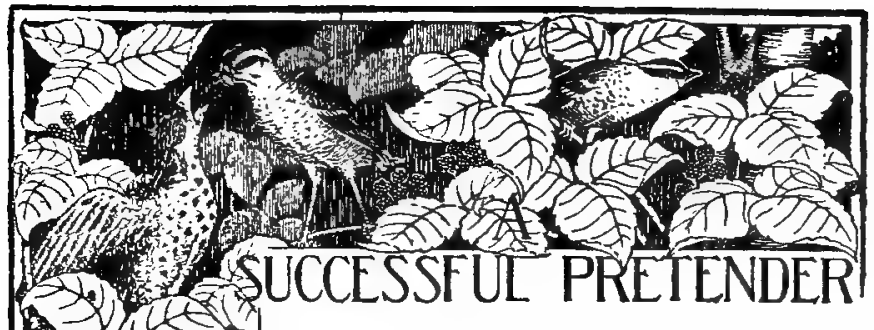

A GREAT, callow, overgrown Cowbird, fed by a diminutive pair of industrious and attentive Chipping Sparrows, is the most palpable fraud of the summer season. The over-burdened foster parents have to stand on tip-toe to reach the open beak of the hungry pretender, who has turned out their own progeny to die helplessly beside the parental nest. How importunate he is ! If they fly across the field he flies after them, as if he were angry at the freedom they presumed to take, and determined by force, if necessary, to make them more assiduous and attentive. But they do not shirk the burden that fate and intentional deception have imposed on them. They skurry about in the edge of the grain field and along the roadside, picking up every insect in sight and returning in haste to the big, indolent impostor sitting on the rail with bill readily agape.

He seems to have a phenomenal capacity for swallowing. No matter how frequent the visits of his little foster parents, he is ever ready to demand more. His insatiable appetite seems to puzzle and worry I05 
them greatly, but they manifest no reluctance, nor do they show any suspicion of the fraud that has been perpetrated or the tragedy that has robbed them of their natural offspring. This thankless gourmand is all that is left to them after the hopes, joys, cares, worries, and trials of their domestic life. The parents of the impostor have evaded their natural responsibilities and are away with a gay crowd of kindred spirits enjoying themselves in the distant cow pasture. There they gather on the ground and flit about as if it were the season of migration, quite unmindful of the parental duties they have unfeelingly shifted to others.

The little Chipping Sparrows found one day an extra egg in their nest, larger than their own, and with a white instead of a blue ground for its even, cinnamon-brown markings. They marvelled greatly at the unexpected addition to their treasures, and held many serious discussions as to whether the strange gift was a piece of good or bad fortune. Some birds revolt against the gratuitous intrusion of the Cowbird, and occasionally the gift is regarded with such aversion that another floor is built in the nest above it, and it is left to its fate. But the Chippies accepted the foundling and warmed it into life. Then the stranger began to manifest the greedy aggression which seems a natural heritage from parents shamelessly neglectful. The rightful heirs 


\section{A SUCCESSFUL PRETENDER}

to all that loving care and sprightly industry were thrust aside, crowded, and crushed. The one ravenous gape was always open as the parents came again and again with caterpillars and other insects. The weaker nestlings were starved and crushed until they gave up the futile struggle. Then they were pushedout of the nest to drop unheeded to the ground. The big impostor grew till he lazily filled the nest, his portly body stolidly immovable, but his soft beak ever open for food.

When he outgrew the nest and fluttered to an adjacent fence the Chippies were more puzzled than proud over their strange, prodigious ward. He was so much bigger than themselves, so obviously able to care for himself, and yet so eager and importunate to be fed. He called to them, demanded of them, and followed them about whenever they made any lengthy excursion in search of the ever-wanted Caterpillars. His mother had left the indifferent flock only long enough to lay the egg in the Chippies' nest and return; and now the young pretender has fastened himself on his little guardians, living upon their industry, though in every way able to support himself. He will never leave them till their deluded parental feelings are strained beyond endurance, and they refuse longer to submit to the imposition. Then he will assume the black plumage of his kind and take himself away to join the band of vagabonds to 


\section{IO8 A SUCCESSFUL PRETENDER}

which he naturally belongs. All summer they move about in small flocks, frequenting woods and open fields while other birds are busy with domestic duties. Their black and rusty plumage is inconspicuous, the females being lighter than the males. Though naturally despised and avoided by other birds, they sometimes find favour with the English Sparrows. These pugnacious little fellows are ignorant or broadly tolerant of the Cowbird's reputation, and they accept him in open and generous friendship. It may be that no bird "is useless while he has a friend." 


\section{BELOW NIAGARA}

A GREAT confusion of gigantic rocks tossed and piled promiscuously together can scarcely be designated "flats," and the modern name "Niagara Glen" seems more appropriate for this fascinating touch of nature's hand than the local name "Foster's Flats." In cutting the deep channel from Queenston to the present site of the falls the waters of Niagara have sported and gambolled in wild caprices, and below the present whirlpool on the Canadian side they have left most delightful mementoes of their savage joy. With ceaseless rush and roar they tore away the lower strata of the rocks, while one by one the great irregular masses of the higher levels broke away with their own weight and settled into the loud, foaming current. Here at one time there was the cataract, its ceaseless strength concentrated on the widening gorge. After it had worked its way backward there was a magnificent whirlpool, and this made for itself a deeper channel on the eastern side, leaving the great abraded masses of rock on the sloping, shelving ledges where they fell. Then in her tireless energy nature set to work to cover the irregular rocks with verdure, choosing many of her most daintily appropriate 
decorations. Pines, Hemlocks, Cedars, Elms, Maples, and Oaks now rise in the giant strength of permanent possession, but the rich and delicate floral decorations of the passing seasons are everywhere abundant.

The history of nature's handiwork is lying open. In the stratified rocks that tower overhead, or are piled about in picturesque irregularity, the marks of marine animal life show that the strata were deposited when Niagara was reached by an arm of the Atlantic. Then comes the wearing and abrasion of the cataract, which searched out and bored into every soft or yielding crevice. The "pot-holes" drilled in the rock seem almost to imply human agency and the use of accurate machinery. The threatening "Great Eastern's stern" hangs ominously over the irregular paths. It has been rounded and formed on good lines by the whirling currents that cut farther and farther beneath it, but found an easier and lower outlet before the great projecting mass was sufficiently weakened to break away from the cliff. Caves and shelters are abundant, and paths are made between rocks that meet overhead in natural arches.

The varied profusion of vegetation among the rocks is seldom equalled. The place is a natural nursery for Ferns and Lichens. Almost every rock is coated and covered, and the graceful, wavy fronds rise from every crevice and recess. The Walking Fern, that reaches out one long, graceful leaf to send 
down a root from its point and produce a dependent offspring, climbs up on the moss-covered rocks in all kinds of inaccessible places. The delicate little Pellaea prefers the high, overhanging face of the cliff, where it secures a footing in the little holes bored by the cataract in earlier days. The Bulbed Fern, with its interesting, seed-like appendages, is quite common, and the tall, imposing Goldiana has found a habitation in the perpetual rocky shade. The Maiden-hair Fern demands admiration, and many other varieties, rare and common, enrich the hollows and crevices with almost tropical profusion. An Indigo Bunting's nest hanging in the fronds of a fern was an interesting discovery. The anxious father came around in his handsome blue coat and chirped excitedly while the mother hid in the Witch-hazel bushes; but only one of the four nestlings was sufficiently confiding to raise his open bill for food. All the wild flowers of the district, from Hepatica to Golden-rod, grow confidingly, the sturdy Painted Trillium and the delicate Herb-Robert being most abundant. Nature's dominion is supreme in the glen, and her handiwork is there, from salt water molluscs to conifer trees. Vegetation is splendidly neglected and at the same time safely protected from landscape gardeners. and other vandals. 


\section{AS THEY TAKE THEIR FLIGHT}

THERE is something pathetic in the eagerness of pent-up humanity to escape from the city into the open world, where all nature is glowing in the lifegiving rays of the sun. A sudden appreciation of the charms of this surrounding richness has come just as they have begun to recede and disappear. In earlier days, when the forest, with its endless variety of life crowded in and about on every hand, the joy of a great presence was felt unconsciously. Children called from the clearings in answer to the plaintive cry of the Wolverine that came as the infantile voice of the forest. In following the uncertain sound of the Cowbell they gained an instinctive perception that led them safely through the tangled underbrush of trackless woods. The Loon laughed and called on the Cedar-girt lake. Every night the long howl of the wolves impressed on receptive minds the cruelty of nature's warfare. The Owl cried out in startled sadness. There were no bonfires built, but the family gathered around the potash kettle and watched the sparks rising among the invisible branches, and the glowing, breaking, tumbling coals, as the red-hot " melt" emitted its tiny blue flames, or glowed, a 


\section{AS THEY TAKE THEIR FLIGHT II3}

solid, silent mass of blinding heat. Trees existed only to be cut down, and logs were an encumbrance on the ground, to be reduced to ashes. Animals lived but to be shot and trapped, and devoted to a multitude of uses.

There was no study of nature in those days, for the growth of knowledge was as imperceptible as the expanding of the leaves. The Snowbirds, Chickadees, Crossbills, and Grosbeaks were welcome and entertaining visitors during the winter, but the grouse was treated as a domestic fowl, especially when the food supply was short. The silent coursing of the sap was the first awakening of spring, and troughs, pails, buckets, and kettles were called into requisition. Then came the swelling of the buds on the Basswood, the earliest fodder for the weakened cattle; and through the entire year life was a struggle toward harmony with nature's inexorable routine. Every sound that reached the ear had a meaning. Every track, cut, and abrasion was seen and recognised. The atmosphere was instinct with life and rich with the blended odours of the woods.

It would be a great mistake to say that all this world of natural life was not appreciated. It was more than appreciated; it was lived. Now we must be content to effect an escape from the busy haunts in the fullness of summer, and regain for a few days the blessing of liberty. Nature always holds out a welcome. She 


\section{II4 AS THEY TAKE THEIR FLIGHT}

takes the scales from eyes which have been mercifully deprived of sight, lest the crowding multitude of objects in the streets excite a wearied brain to distraction. Once the lost sense is restored, the trail of the Muskrat, the print of the Squirrel's foot on the sandy bank of the creek, the scars where the Porcupine gnawed the Beech, or the Deer rubbed the velvet from his horns, the nimble disappearance of Creepers and Warblers, and the many traces of nature's activity are seen with all their old distinctness.

In the abomination of city vapours nature has dulled the sense of smell, but it is restored with the blended odours of the Pine, the Birch, the Sassafras, and the Balm-of-Gilead. The myriad noises jarring on the ear have caused a happy deadening of the sense of hearing, but out in the heart of the woods the old discernment is restored, and the liquid notes of the Hermit Thrush away in the distance arrest and hold the keenest attention. Every sense is on the alert, that none of nature's manifold gifts be wasted. All her aspects are studied with the closest interest. Every tree and every flower becomes a new revelation. We feel that the great treasure-house is gone, but prize all the more highly the remnants of wealth that remain. Even the suburban ravines, marshes, and woods, where wild life, driven from former habitations, finds shelter in the indifference of a city, take on the charm of the primeval forest. There we can 


\section{AS THEY TAKE THEIR FLIGHT IIS}

close our ears to the rumbling of the locomotive, the discordant shrieking of steam whistles, and the clanging reminders of the tyranny of time, and feel all the inspiration of a world of growth where "the great heart of existence beats for ever like a boy's." 


\section{THE GREAT NORTHERN DIVER}

Out of the night comes the weird, long call or the shrill, demoniacal laugh, telling of the sleepless activity of the Loon, or Great Northern Diver. The Whip-Poor-Will in the adjacent shrubbery seems companionable, and there is a friendly spirit in the short, shrill tremolo of the Night-hawk from the invisible sky. Even the plaint of the Screech-owl has a tone of human sympathy. But the dreary cadence of the Loon is the voice of the inhospitable night, repelling every thought of human association. It does not entreat, it does not warn; yet there is a fascination in its expressionless strength. Over the black water, under the lowering sky, or through the bright, still moonlight the same unfeeling tone fills the ear of night. And sometimes, when the lingering moon sheds a broad trail of light along the still waters of the lake, the graceful swimmer will glide across and disappear in the darkness, breaking the bright reflection into a multitude of chasing, quivering, trailing threads of silver. Throughout the day, where the Cedars come down to meet their shadows in the dark water, he swims ceaselessly about, sitting low, with black, glossy neck gracefully curved and dis- 
playing its delicate white markings. Sometimes he stretches himself wearily, flapping his wings and displaying his white breast and the handsome, showy markings of his sides. Though wary and aloof, and without a trace of animation in his loud, penetrating cries, he shows his kinship by the scrupulous care with which he preens his handsome feathers-even lying on his back in the water to comb out and smooth his glossy white breast.

A hurried cry from overhead may unexpectedly reveal the presence of a pair of Loons in another element, and it is always fascinating to watch their steady, strained, energetic flight above the tops of the pines, generally to curve down to some more attractive expanse in the Cedar-girt lake. For the water is the Loon's natural element. There is an amusing deliberateness in his graceful, silent dive. He does not make the hurried dip of his smaller cousin, the Grebe, but more calmly curves both neck and body, disappearing under the surface in a graceful arch. Settling down and swimming with only head and neck exposed is an evidence of suspicion, and is generally followed by a long dive, with a belated reappearance in some remote part of the lake.

When the mother Loon takes her two offsprings out for a swim it is a big event in the domestic circle. The outing is announced by prolonged and unusual repetitions of the laughing call. For half an hour the 


\section{II8 THE GREAT NORTHERN DIVER}

echoes of the lake are kept alive with sounds portentous of new departures in the Loon world. Then a peculiar object is seen to emerge from the marshy bay and cross under the shadowy Cedars toward the open water. A field-glass shows it to be the mother Loon and her two offsprings, the three huddled so closely together that they are almost indistinguishable. The mother is unceasing in her care and attention. She strokes the backs of the young birds with her bill, playing and fussing around and close to them, as if they could not exist without her constant attention. Now and then she leans over and lifts a broad, black, webbed foot out of the water, holding it up distended, as if to endorse the modern theory that the parent Loon teaches her young to swim. They cling to each other and cling to her, as if afraid of being lost in the great expanse of water to which they have been so recently introduced.

A short distance away the father swims about in lordly indifference, diving occasionally and regaling himself on unsuspecting fish. A boat comes out from the shore, rowed by an industrious guide, with an angler, picturesquely protected by a mosquito net, sitting in the stern. The mother Loon pushes and urges her indolent pair in the direction of safety. How slow they must seem as she hurries and encourages them! The trio moves at a snail's pace compared with her ordinary speed, and they show no 


\section{THE GREAT NORTHERN DIVER II9}

inclination to dive out of harm's way. Their clinging, crowding tendency serves but to incommode and obstruct her. And where is the male protector? Alas for the romance of chivalry! When the boat comes near he deliberately dives, and, after the usual protracted wait, reappears in another part of the lake, away from the danger that alarms and threatens the defenceless trio. But the mother remains and urges the encumbering young things to speed. They do make some headway, though slowly, toward the marshy bay from which they recently emerged with so much loud, wild laughter. The indifference of the fisherman and the guide do not reassure them, and they never cease their entangled struggle till lost to sight in the winding lagoon. 


\section{THE POWDER POST BEETLE}

JusT as we begin to congratulate ourselves on the growing usefulness of our abundant hardwood timber, a persistent little pest comes on the scene to disturb our complacency. He does not attack the forest trees nor the newly-cut logs, but waits till the lumber is well seasoned in the yard or made up into furniture, carriages, mouldings, and interior fittings. Hickory, ask, and oak are his favourites, and, although he does not like paint, varnish, or other finishes, he is not always dissuaded by them. A little fine powder scattered on the ground or the floor is often the only warning, but it may indicate that the spoke of a carriage or the leg of a chair is so completely bored and riddled that it will scarcely sustain more than its own weight. Perhaps there is no intımation until some part of an apparently solid piece of furniture is shattered into dust and splinters with a light blow. The little beetle responsible for all this mischief has long been a source of vexation and annoyance in Britain, but his recent depredations on this continent have been sufficient to prompt a vigorous pursuit by the Washington authorities. Already he stands convicted of occasioning a fatal railway accident by 
destroying the timbers in a bridge. As he leaves no external marks of his operations except the fine brown powder he scatters about and the pin-holes through which he enters and emerges, the weakened condition of the wood he has perforated is not readily discerned.

A slender Beetle, less than a quarter of an inch long, can penetrate rough or even finished hardwood without leaving any conspicuous marks. The eggs are laid in the wood, and when the minute white grubs are hatched they burrow in and through the wood in all directions, feeding and growing until ready for the inert sleep of the pupa stage. For this transformation each diminutive grub forms a cell at the end of its burrow. When its legs and wings are fully developed it awakes to new life and bores its way out, a perfect beetle ready to transmit the destructive life it has inherited. The dry, hard woodwork of carriages, the handles of tools, the material of finished interiors, old furniture, hardwood floors, joists, and frames are the strangely acceptable diet of this dangerous intruder. But he fortunately confines himself almost exclusively to the sap wood. All wood from the heart of the tree is virtually safe. With our abundance of hardwood there is no excuse for using the vulnerable part and thus providing costly food and lodging for this pest. If we are sufficiently parsimonious or dishonest to use sap wood we will be courting punishment. 
Each female deposits many eggs, and a number will attack a single piece of furniture. The numerous progeny making their winding burrows through the wood completely destroy the interior fibre, reducing it to a mass of fine powder. If the destruction is not accomplished by the first attack, the process is continued by subsequent generations until a thin outer shell is the only solid fibre remaining. The drier and older the wood the more attractive does it become, and the beetle has a special fondness for floors, joists, frames, and material that has lain undisturbed for several years. Steaming, dry heat, and a liberal application of kerosene or benzine are among the recommended methods of destruction. Sap wood should be rejected for all purposes, and all wood in which the pest has found a lodgment should be destroyed. Carriage woodwork and antique furniture frequently suffer. Look for the light brown, mealy powder and the pin-holes. They are signs which reveal one of the wonderful concentrations of destructive power in the insect world. 


\section{A FLOATING ISLAND}

WheN a buoyant, matted entanglement of Bulrush roots is undermined and loosened from its feeble hold by the swollen water of the marsh the wind takes hold of the multitude of fluttering green sails, and the unstable island moves almost imperceptibly toward other shores or anchorages. Where the water is clear and open the wind, tugging at the tall, crowded rushes, moves the island steadily along, making panoramic changes in the confining and reflected vegetation. In a mass of submerged weeds it is retarded so gradually that its movement ceases imperceptibly. It has all the features of the solid islands and shores adjacent, and shows no evidence of the fact that it is merely waiting for a change of wind to seek other and less obstructed routes of travel. The inhabitants seem perfectly satisfied with their itinerancy. A Gallinule clucks familiarly and contentedly in his safe concealment, quite unmindful of his wanderings. He even ventures out to the floating margin, stepping daintily among the yielding roots, and picking the small snails and larvæ that cling to the sunken rushes. The bright red of his bill and frontal plate relieve his funereal colours as he 
swims out into the sunlight. With long, distended, slender toes he is a poor swimmer, but does not seem eager to increase his speed. Leisurely idling on the clogged water, he seems a natural inhabitant of a floating island. His indolence suddenly ends with a fluttering, splashing rush into the floating haven, and the cause of his sudden alarm is seen in the careless approach of a canoe.

Marsh Wrens dart about among the waving rushes, scolding the invaders and creating a continuous disturbance. Sora Rails chatter loudly, as if determined to make the protest more effectual, but the hiding Gallinule is discreetly silent. Two globular nests of the Marsh Wrens are neighbourly adjacent in the suspending rushes, but these little atoms of industry often build more nests than they require. A Redwing's nest, from which the brood has no doubt departed, is also supported by the new vegetation. The inhabitants of the marsh are in no way reluctant to choose so uncertain a location, and as it floats about they continue to hide and rear their young in its friendly shelter. A Carolina Rail, with long bill and awkwardly pendent legs, rises from the rushes as if he were about to desert his unstable home, but after a short, slow flight over the waving green blades he drops again out of sight. A little Bittern, with folded neck and trailing legs, rises less irresolute and flies over the open water to the more permanent vegeta- 
tion of the shore. This is not the beginning of an exodus, for through the growing dusk some wandering Redwings turn abruptly from their course and settle among the tall green blades. As night settles down and the stars come out the wind that moved the island against the weedy shallow is stilled. The tallest Rushes stand limp and motionless. The Sora Rails chatter in continuous alarm, while all the other inhabitants are silent. After the impressive pause of the end of day a long line of dark ripples extends over the open water. The Rushes begin to quiver and tremble in the mild ebb of the silent air. The island remains where it was stopped by the weeds, but soon a change of position can be discerned. The returning air currents pull with gentle persistence. Soon it becomes apparent that the floating island, with its concealed inhabitants, is slowly drifting out toward the close horizon of the night. 


\section{ACTIVE GLEANERS}

Advancing summer brings a period of silence in the Bird world. The happy notes of the Song Sparrow still enliven the woods. The vigorous but less melodious call of the Yellow Warbler is still heard, and $a$ few other perpetual singers keep the spirit alive. But in contrast with the chorus of early spring the woods are silent, relieved mainly by the distressed calling of hungry fledglings, impatient at the delay of their tired parents in distributing food. Young birds that have left the nest but are still in a dependent position are a serious problem to parents, struggling energetically to keep all wants supplied and silence all turbulent outcries. The quiet of the season affords an opportunity to watch the ceaseless activity of the little gleaners. The Warblers in bright and varied colours are skimming about over leaves and twigs, picking off every insect that has found a lodgment there. The Yellow Warbler is perhaps the most industrious and most familiar, although his fondness for the close-leaved tops of trees, where the sun strengthens the yellow tints of the green, often shields him from observation. He is revealed by 
his perpetual energy and the occasional hurried call, given out without pausing in his work.

The insect world may hold itself in check by the parasitism that besets every species. Perpetual warfare holds, controls, and restrains a possibility of reproduction sufficient to devour the world's vegetation. The balance of contending forces has swayed but little during the comparatively brief period covered by human observation; and a lazy summer hour watching the ceaseless activity of the birds reveals their important part in the struggle that holds insect life in check. They are indiscriminate, it is true, feeding as freely on the useful parasite as on the injurious leaf-eater; but they are an established element in the perpetual conflict, and cannot be destroyed or removed without grave danger.

Birds destroy insect life in all its forms. Nowhere are the insects safe. Woodcock, Snipe, and other shore birds bore for them in the mud and sand. Robins pluck them from the hard earth. Thrushes turn over the leaves in search of them, Woodpeckers bore into the trees for them. They are caught on the wing by Kingbirds, Phcebes, Night-hawks, Swallows, and even Warblers and Sparrows. Nuthatches and Creepers search every crevice in the bark for them. The nimble little Warblers go swiftly and patiently aver every branch, twig, and leaf, as if determined 
that no insect should be left alive, and birds of less regular habits pick them up indiscriminately wherever they can be found. Where bird activity is unmolested it seems almost strange that any insects escape. All are devoured at sight. Even the obnoxious Potato Beetle, once regarded as enjoying immunity, is food for the Whip-Poor-Will. When the nestlings are first demanding attention the greatest destruction occurs. Although parent birds may show a preference for fruit and other delicacies, the young demand an insect diet. That accounts for the insectivorous activity of the Catbird, the Brown Thrasher, the Robin, and other birds which show an epicurean weakness for fruit in season. The crusade against all kinds of insects is joined by the Blackbird and other grain-eaters. Even such marauders and outlaws as the Crow and the English Sparrow like to treat their young to an insect feast. The Ruby-throated Humming-bird, dainty enough to subsist on the nectar of flowers, is a plebeian feeder on Gnats, Ants, Flies, and minute parasitic Wasps. The Sparrow-hawk lives largely on Grasshoppers, but more formidable members of the family do not descend to insect food. Partridge, Quail, and Prairie Chickens, destructive grain and bud-eaters as they are, feed their young on Grasshoppers, Beetles, Cutworms, Caterpillars, Maggots, Chinch Bugs, and similar delicacies. Although this destruction goes on by night as well 


\section{ACTIVE GLEANERS}

as by day, although the winter residents are gleaning insect food perpetually, and the great feast of the nesting season is held when the ephemeral swarms are most freely exposed, the strange mutations of life in the insect world go on from year to year, a triumph of the all-pervading instinct of perpetuation. 


\section{FLOCKING ALREADY!}

WHEN the rich abundance of summer vegetation prompts a reposeful wish for the perpetuation of the season, a flock of Blackbirds hurrying across the open sky between the rounded oak tops give a hasty reminder of the universal law of change. They are flocking already, and the summer seems to have scarcely yet arrived. Their diminutive and disreputable cousins, the Cowbirds, have been flocking all the year. They shirk the responsibilities of life and shift the care of their offspring to others. Throughout the spring, when other birds are building nests and perfecting their domestic establishments with ardent, happy industry, these little outlaws are congregating in flocks and loitering idly about the pastures. Now and then a solitary female will skulk away from the flock to deposit an egg in the nest of a Sparrow, Finch, or Warbler, returning again to the vagabondia of her kind. This flocking merely betokens parasitic idleness, but the flocking of the large Blackbirds, early and unwelcome as usual, tells of the passing of another season of growth. Unlike their little cousins, they are models of domestic virtue. As soon as they arrive they proceed at once with the 
selection of a locality for nesting and rearing their brood. The work of building absorbs all their attention, and they are quite indifferent to the less weighty problems of Blackbird life. They never wander far from the nest, not even when the young, importunate brood make extravagant demands for food. They gather delicacies all day long, never venturing far afield, but gleaning from the adjacent swamps and bogs. The conduct of the Blackbird at this time is most exemplary, even from a selfish, human point of view, for he provides a bill of fare consisting largely of insects.

As soon as the cares of the household are thrown off and the young brood are able to battle with the world the Blackbird becomes the most sociable of all the summer residents. Then the sudden appearance of a hurrying flock gives a disquieting reminder of the passing of summer. The new flock lacks organisation or purpose, and seems too happy to think of the pursuit of pleasure. The restraints of a season of domestic care are forgotten in the glad abandon of a new life. This is the time for raids and depredations. The fields of ripening grain are an irresistible temptation. The flock scurries here and there, settling for a moment to gather a few grains of Wheat, and rising in response to an irregular impulse, to disappear among the crowding Maples. There is no leadership among the hurrying marauders as they move about 
with rapid hesitancy. That may be why the flock is so crowded and compact, with scarcely room for uninterrupted flight. In this eager flocking the peculiarly deliberate antics of the solitary bird in the spring marsh are entirely lost.

Away they go out of sight behind the low treetops, but their passing has brought vividly to mind the ceaseless transformations of animated nature. We may long for a period of repose or for the permanence of the richness of summer, but the same inexorable law of change, of death and resurrection, is relentlessly unfolded. The unexpected flocking of the birds is but one of many evidences of transition. High up on a sturdy Elm the foliage on a solitary branch is taking on a yellow tint. Here and there a Maple is touching the dainty tips of its leaves with colour. The Goldenrod is unfolding its rich and brilliant plumes. The richest of the Purple Asters are glowing through the interlaced green. And in the air there is that vague, chill feeling of loss that seems an anticipation of the inevitable decline of all that fills the season with joy and satisfaction. 


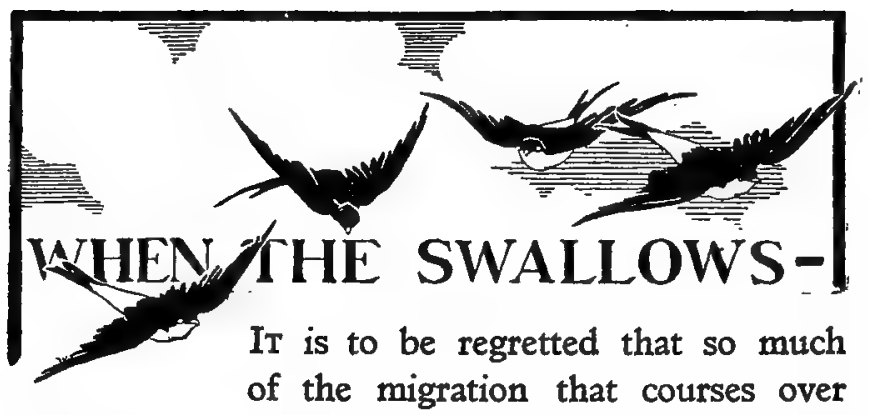
the continent is carried on at night. The sky seldom reveals the strange wanderings from zone to zone. The welcome arrival, the indifferent passing to and from remote homes and haunts, as well as the affecting departure, are all shrouded in darkness. Sometimes a flock of Wild Geese may pass high and distinct against the clear day. Ducks in angled lines, more hurried and more near, may court the daylight. Even in the night a familiar note may come from the upper darkness announcing the route of some passing traveller. But the swarms that move between tropical retreats and northern breeding grounds prefer the secrecy of night and lose the wider sympathy that would come from a free disclosure of their routes and journeyings. Swallows are now gathering in large flocks and making ready for the great journey. The marshes are favourite places of assembly, and when they crowd the wires in thousands one is apt to wonder how they managed to organise preparatory meetings before electrical inventions furnished resting-places. Some- 
times they declare their independence by perching on the dense, strong vegetation of the marshes, but the wires are favourite roosts. This shows a ready adaptability. As the Swift, easily distinguished by its round tail and dull, sooty plumage, adopted chimneys in preference to hollow trees, so the Swallows, also feeders on the minute insects of the air, prefer the wires to their old and natural perches.

The Bank Swallows organise the most conspicuous flocks. As is their custom, the place where they swarmed noisily in the evening, filling the air with their disturbed chattering and scarcely leaving room in the air for their insect food, will be left in the morning silent and deserted. Their plumage is dull, dark above and light below, and the dark breast band makes a conspicuous mark as they line up on the wires. They are industrious burrowers, and have reared their young in holes in the many favourable banks furnished by cliffs and ravines. The Barn Swallows, the most gaily decorated of the family, have already begun to leave for the south, but a few remain and will probably join the flocks of their relatives. Reddish breasts, glittering blue-green backs, and deeply-forked tails spotted with white, distinguish them from the other swift chatterers that pursue the insects rising from the marshes. They are good masons, and attach nests of mud to the rafters and eaves of barns. The Tree Swallow is 
generally early in flocking, but inclined to linger as long as food is abundant. Metallic blue-green above and pure white beneath, the white and colour meeting at a distinct line from the bill-this Swallow is readily distinguished and always admired. The Cliff Swallows are less familiar and seem to be decreasing in numbers. They have the mud-building habits and also the metallic blue-green plumage of the Barn Swallows. Reddish patches on the neck and above the tail are marks of identification. The big Black Swallow or Purple Martin is also becoming less common, and is said to show a growing inclination toward passing the summer in its southern home. The gathering of the flocks is a reminder of the passing of summer. Even in the oppressive and close evenings their chattering and crowding announce the distant approach of the frost king from the north. They will not wait for his blighting touch, but will seek the freedom of perpetual summer before the first chill of his approach. 


\section{THE FASCINATION OF LIGHT}

LIGHT has a strange fascination which takes hold of all animated creatures, and commands a subtle devotion that cannot be set forth in a confession of faith. The delight of a boy in a bonfire is a breath of the heaven that is about us in our infancy. Though it be but a heap of rubbish, revealed by the removal of the mantle of snow, lighting up with flickering, changing glow a rectangular door yard, the children stand and gaze into the dancing flame, their vast, distorted, ghostlike shadows lost in the night, their faces reflecting every evanescent glare. and their spirits charmed by the same spell that took form in the fire-worship of their ancestors. How they delight in stirring up the embers and sending up a fountain spray of sparks ! What joy in seeing the big sticks break into glowing coals, darting out new tongues of flame to lick up the escaping embers !

Fire is one of nature's universal fascinations. The wildest and most wary animals approach and gaze at it in the night, and though it sometimes warns them off, it always holds them by a spell. The night migrating birds perish in scores against the plate glass of coast lighthouses, swerving from the control of the all-powerful migratory instinct toward the fascinating glare that is their destruction. It is not sportsmanlike to hang a lantern in the marsh and 
shoot the ducks that gather under it. But the night, the silent marsh, and the lantern have charms that the sportsman, with his legal and mechanical paraphernalia, can never understand. Fish are devoted fire-worshippers, and that boy who has never speared by a jack-light is an object of compassion.

The earth and the waters under the earth have no more fascinating sight than the grey, silent form of a Pike, moving and motionless in the shallow water, a shadow more tangible than himself thrown by a jack-light on the mottled yellow rocks and sands of the bottom. A passing breath of wind, even the slightest motion of the punt, breaks every shadow and indentation into myriad fleeting ripples and waves of light, transforming the slender, silent fish into a sheaf of wriggling glimmers. With the stilling of the surface the waiting Pike and all the shadows and lights of the bottom grow once more still and distinct. There floats the greatest cannibal of the fishes, paying his devotion to the flame, and above him stands the greatest cannibal of all created beings pointing his deadly spear.

There is no moon. The stars cannot penetrate the thickening clouds. The bay is still and its shores invisible, the distant light of a farmhouse only serving to intensify the lonely silence. The savage joy of that moment repays the boy for all his laborious preparations. He brought two boards down the river from 


\section{I38 THE FASCINATION OF LIGHT}

the mill, and toiled at them with all the tools in the woodshed till the ends and edges were made smooth. $\mathrm{He}$ collected lumber from all available sources for the ends and bottom, fastening them on with a miscellaneous collection of nails and sprigs. Then he patiently picked an old piece of tarred rope into cakum, and calked it into the seams with a sharpened gate-hinge. He notched a Pine tree, gathered the gum and boiled it into pitch to make the joints tight. That extraordinary pair of oars he sawed, chopped, and whittled from an old plank. The spear is a family relic which he dug up and fitted with a white-ash pole, and the anchor is a long stone, tied by the slack of a clothes-line. The jack is a basket made of old pail-hoops, and fastened to an upright stick to hold the burning pine knot. Yet we wonder why it is always the country boy who succeeds in the city.

Will he, too, be lured by the seductive glimmer? Will he turn away from the conquest of nature and embark in the conquest of his fellow-mortals? Will he go to a resort for his fishing and a preserve for his shooting? Will that bunch of hair protruding from under his hat be worn thin and grey in scrambling after the delights of the vain and the covetous? Will he devote his superb strength of body and mind to outstripping and circumventing his fellows in the pursuit of that transient glimmer, that all-alluring ignis fatuus which the Babylon world calls success? 


\section{THE CANADIAN MOCKING-BIRD}

THIs most versatile, and perhaps most musical, of all our feathered singers is enjoying the inspiration of the season and contributing to the melody of the lengthening evenings. His sombre coat of slaty grey, darker on the head and tail, lends aid to his naturally secluded habits, for he likes to move about among the low thickets, where his disappearing form may sometimes be mistaken for a Robin. The under tail covert of chestnut or dark red is a distinguishing mark which sometimes aids identification. But the Catbird, as he is more familiarly called, is generally recognised by his varied accomplishments. The decided, colloquial mew, as of a vagrant cat, coming from the Alder, Dogwood, and Hazel bushes, is often the first intimation of his presence. He does not long adhere to the disquieting feline sounds, but breaks out into an answering melody, sweet, clear, and of wonderful compass. The shrillest trebles alternate so quickly with the richest altos in the bird register that a listener is easily deluded into fancying that two birds are singing together. Then the cat mews again, and the singing seems scarcely interrupted.

Throughout the entire day the thickets are enlivened by an occasional strain from the hidden singer, but as evening advances and the sunlight 


\section{I40 THE CANADIAN MOCKING-BIRD}

withdraws to the hilltops he abandons himself to the sustained ectasy of song. Then he forsakes the deeper shadows and comes up into the open branches, where his nimble and varied antics amuse, while his song sustains its melodious charm. For a moment his long bill will energetically vibrate to the shrill prestissimo, then it will close, and from his inflated throat will come the deceptive, ventriloquial notes that seem to proceed from the recesses of the woods. The catcall will follow, as if he were tuning his vocal chords, and again the melody flows forth uninterrupted. There are many imitations in his song, for he borrows freely from the Warblers and Thrushes. But he gives forth his own spirit so abundantly that all his pilferings are forgiven.

Though keeping to the low thickets, the Catbird is by no means unfriendly. Once assured of the good intentions of a visitor, he comes out quite freely and in ready confidence. A friendly, trusting pair will even nest in the vicinity of a suburban house if the people are properly appreciative. The nest is a big, straggling affair, and the birds seem to take delight in using a number of abnormally large and unnecessary sticks and broken roots. The large mass of building material fastened in a low thicket serves the purpose of concealment, and is less noticeable than a compact, regular nest. The three, four, or five eggs resemble those of the Robin in colour, but are much 


\section{THE CANADIAN MOCKING-BIRD I4I}

smaller, and the anxious mother is terribly distressed if an intruder ventures near.

These summer residents vary their diet with the changing seasons. On their first arrival they explore the naked thickets and evergreens, and hurry over the ground and among the leaves in search of insects. Beetles, Spiders, Worms, Ants, Grasshoppers, in fact all kinds of insects, are eagerly gathered. The birds often pause to sing at their work or to perform some extravagant antics for the entertainment of a visitor. When the young nestlings demand food the mother is unceasing in the pursuit of insects, and is said to be so energetic that she will assist in feeding the young in other nests. If the Mulberries ripen sufficiently early the nestlings are treated to their full share of the new delicacies, and as the season advances and the fruit becomes more tempting the insect diet is almost entirely abandoned. Then the valuable service of the earlier season is forgotten, and the Catbird is inconsiderately declared a thief and a vagabond. But friendship and affection are superior alike to the evil reports of busy tongues and the deliberate condemnation of the gravest judges. Friends who have listened to the varied songs of the Catbird in the evenings of early spring or watched his amusing activity in the naked shrubbery will freely forgive his depredations and reserve for him a favoured place among the guests of summer. 


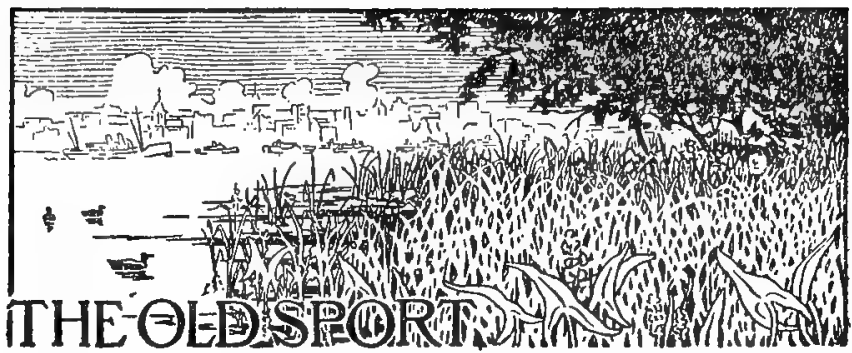

WITH the Dog Star low in the south-eastern sky and the crescent moon rising to peer through obscuring clouds, the silence of morning commands a subdued respect almost akin to reverence. Slowly moving forms, distorted by the uncertain light that outlines them against the still water, seem to make the hush more oppressive. The air is still, and there is not even a tremulous motion among the tallest rushes that rise above the impenetrable and entangled growths of the marsh. Clouds hang low, as if festooning the great invisible dome. The grandest temple that man can rear is weak and insignificant compared with the vast solemnity of the open, lingering night. This allenshrouding temple is suddenly profaned by a swift, red flash followed by a harsh, explosive report. Flash and report follow again and again in close irregularity, some near and some dulled and almost invisible in the distance, where the long, extending shore is still curtained by the night. Answering reports come in rapid succession from the concealed reaches of the marsh, and before there is a trace of day in the east 
the solemnity of night is transformed into the keen activity of a fusilade of destruction. The shore waders that have been feeding and fattening under the protection of the law are exposed to the yearly attack.

Two great Herons aroused by the unusual sights and sounds rise with inquisitive croak and fly low from the outer shore toward the rush-protected water. Flashes and reports along their course seem to confuse them, and the usual grace of their steady strokes gives place to momentary awkward turnings as they pass close from the invisible to the invisible. The first hurried flight of the hunted is seen reflected in a long, shallow lagoon imprisoned by a stretch of sandy beach. The birds are invisible against the background of Willows and Rushes, but in the natural mirror of the Lagoon the light from the moonlit clouds reflects their passing forms. They are Ring-necks and small Sandpipers, bunched close with quivering wings, and their mirrored forms seem to shudder rather than swerve at a startlingly near report. The fusilade continues wherever the uncertain light reveals the location of the restless and startled waders. It grows more noisily aggressive as the advancing sunlight blots out the Dog Star and the faint crescent. Flashes are no longer visible, but the noise increases as the disturbed and hunted flocks scurry along the shore in a helpless, eager search for 



\section{A MIGRATING BUTTERFLY}

THIS is the season to watch for the migration of the orange and black Butterfly, familiarly known as the Monarch - to his intimate friends, the Anosia plexippus. In the insect world, the world of myriad wonders, this familiar dweller among the nectarladen flowers is the only migrant. And why should insects come or depart with the changing seasons? Ephemeral atoms in the great sea of life, at one time crawling on the earth like reptiles, at another flying in the air like birds or swimming in the water like fish, again burrowing in the ground like moles, and relapsing into inert forms that sustain, like seeds, the mystery of life through the fiercest northern frosts, sometimes eating voraciously and again sustaining a life of activity without food, they change with the passing seasons, dancing in the summer sun or congealing in the frozen earth in winter. But the Monarch Butterfly, familiar in his dizzy, undulating flight among the chimney tops or feasting daintily on the nectar of the Clover, is impelled to go from zone to zone in the fulfilment of his life mission. In the middle of the big lake his indolent, irregular flight seems purposeless and indifferent. He seems to heed 


\section{I46 A MIGRATING BUTTERFLY}

the passing steamer no more than the passing of time. In his giddy flopping there is no apparent progress, and one wonders how he traverses the length of the continent to spend the season among tropical flowers, how he crosses the Gulf of Mexico to a still more attractive climate, and how, a few years ago, he crossed from the southern extremity of this continent and invaded our sister colony Australia. Around Toronto these Butterflies generally move westward, and, although they are sometimes encountered over the lake, it is thought that the flock or swarm from this part of the country crosses at Niagara. It is only three or four days after their departure that they are tasting the nectar of the flowers in Florida and other States around the gulf.

With their migrating habits there is a resourcefulness that other insects do not possess. The greater part of their life is spent not in the inert chrysalis state, like so many of their class, but in the highest activity of perfect development. Their wings must be protected for the long flight. When their delicate scales are threatened by a storm of rain they hide under the little twigs of the Willow, where they hang back downward, their wings closed flatly together below them in the position they often assume when resting on the flowers. Sometimes they seem to forget their usual caution in a shower and fly excitedly about, hither and thither, rising higher and higher 


\section{A MIGRATING BUTTERFLY}

in an apparent effort to get above the rain. But that is only an occasional folly, for they generally anticipate the storm and suspend themselves carefully out of harm's way. The young generation, ready to try their beautiful, untarnished wings in the long southern journey, will not have the guidance of experience. That is a means of progress and advancement denied in the insect world, for each generation passes with the fulfilment of its procreative mission. As long, black and white crawling larvæ they have been feeding voraciously on the leaves of the Milkweed, a plant named after Asclepias, whose knowledge of medicinal herbs was so profound as to excite the envy of Jove himself and thus led to his undoing. And the Butterfly larvæ, whose preference for the Milkweed is no doubt more wise than the medicinal faith of the earlier generation, have also inherited the name.

A short time ago they ceased devouring the Milkweed leaves, curled themselves up for a brief nap as inert pupx, then burst from the shroud of their own weaving as winged insects, their jaws discarded for long tubular tongues to draw the nectar from the nodding flowers above the leaves they so lately disfigured. They have changed from the Caterpillar to the Butterfly and turned from the leaf to the flower. Their long southern migration is merely a climatic necessity. They will come back again in the 


\section{I48 A MIGRATING BUTTERFLY}

spring, meagre and ravenous, their wings worn and battered by the long flight. They will probe the horn of the Columbine, the slender tubes of the Honeysuckle, and every flower that promises them nectar. The exuding sap of the Maple or Birch will be a rich repast, and they will revel for a time in the luxuriance of our northern land. Soon they will seek their mates, like the returning Swallows, and give up their lives in the fulfilment of the law of perpetuation, the first law of nature. 


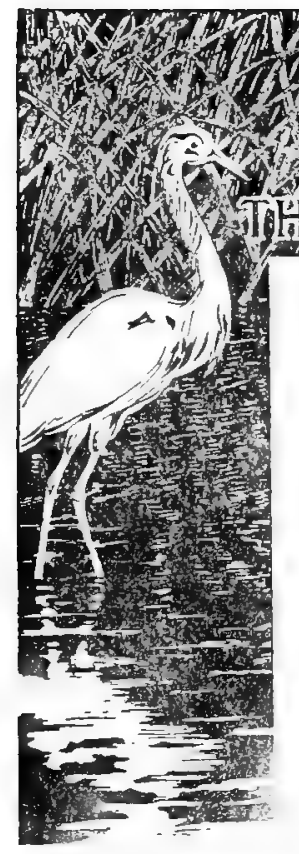

DeLIBERATE, strong, steady, and regular, the Great Blue Heron moves through the upper air, now outlined against the deep and limitless azure, and now seeming intent on burying himself in the suspended folds and undulations of fleecy cloud. He has travelled from the warm, vapoury, and impenetrable marshes of the south, and is breasting the clear, invigorating northern air toward his summer home in the forest. The city, with its offensive odours, is but a small and trifling defacement on the great continent he freely regards as his own. The swamps are still solid with the lingering ice. The Frogs and Snails that must provide his food are still in the long sleep of winter. Fish that might fall victims to his darting beak have not begun to ascend the creeks and rivers. Yet, indifferent to the season's delay, he pursues his northward course with slow, unvaried strokes, his head drawn back and resting on his closely curved neck, and his long legs 
trailing rigidly behind. It seems a strange hope that impels him where the persistent grip of the frost is stronger and stronger, for the slowly awakening landscape over which he is passing is not yet prepared to serve his many needs. The eye follows him as his great, distended wings grow smaller, and he seems in the deceiving perspective to gradually descend toward the northern horizon. On and on he goes, responding to the impelling urge until he becomes an uncertain spot on the darkening grey into which he slowly vanishes.

The varied panorama of his life passes in fancy as he disappears in the northern distance. The months of indolent ease he spent among the rich verdure of the southern swamps, protected from intrusion by their impenetrable growths and the poisons of their vapour and their ephemeral life. There in the richness of solitude, wading slowly through the stagnant water, his long white neck made a clear outline against the dark green of the perpetual shades either in the graceful curve of repose or the tall, strained rigidity of alarm. The narrow, pendent feathers of his breast, reaching the surface of the water as he wades, are supposed to attract the fish and amphibians on which he feeds. But whether these victims are attracted or fascinated, there is death in the swift stroke of that great, powerful yellow beak. There is no more graceful bird than the Blue Heron, and nature seems 
to have made a special effort to harmonise the form, colour, and movements of the bird with the tall, rich vegetation of the marshes.

With the awakening of the far and hushed north the Heron moves to his summer home, but does not feel impelled to seek the distant regions beyond the invasion of man. Wherever tall trees reasonably remote from inquisitive human meddling afford a nesting-place he may decide to locate. If left unmolested he will come season after season to the same locality, repairing such damage as the passing storms may have done to the lofty platform of lodged sticks that serves him as a nest. A heron family grows in noisy importunity as the time for leaving the nest approaches. Though the brood may remain silent while the mother is abroad gathering a supply of Fish or Frogs, perhaps occasionally putting forth a long neck to look around over the treetops, every return is greeted with a harsh and rasping uproar that seems almost to profane the stillness of the forest. The parents make long excursions to distant marshes, and when the young, fully grown, but immature in plumage and colour, pass from parental care they make their way leisurely southward from marsh to marsh and from swamp to swamp. They seem reluctant to leave, but take alarm when the noisy slaughter of the game birds disturbs the quiet of their favourite haunts. 


\section{FLOWERS OF THE SEASON}

THERE is something akin to waywardness in the habits of the wild flowers. They choose their favourite haunts, their quiet resting-places and open promenades, with apparent unconcern, but with remarkable fidelity and persistence. Their preferences seem most unreasonable, but that is the way of most preferences. Not only have they favourite climes and latitudes, favourite conditions and surroundings, but favourite nooks, ravines, ponds, and hillsides, where they are certain to be at home in due season to their intimate friends and admirers. The Twin-flower will often choose its own favourite shaded hillside, leaving the opposite slope to its more vigorous companion, the Partridge-berry. There they live their lives, responding to the spirit of the passing seasons, vivifying the spring, strengthening with the fruitfulness of summer, and varying the pattern of the carpet of autumn leaves. Even through inhospitable mid-winter, under the dense covering of snow, their rich green leaves can still be found, full and healthy, an earnest of nature's perpetual youth. Gold is generally found where it is least expected; but the floral treasures have their favourite haunts. Their 


\section{FLOWERS OF THE SEASON}

ways and habits, their likes and dislikes, lend zest to the familiarity that grows with the years.

The northern lakes and streams are specially favoured in advancing summer by the Cardinal Lobelia, the brightest and most intensely coloured of all the wild flora, and by the Scented Water Lily, a younger sister of the White Water Lily, familiar on the quiet waters along the lake. The Cardinal Lobelia often shows a glowing spot of colour on a beaver meadow. It can never be mistaken, for no other flower can rival it in intensity and brilliance.

The nodding flower of the Pitcher-plant seems dull in comparison, and even the brilliant tufts of the Painted-cup, which disappeared earlier in the season, lacked the bright vitality of colour. Along the streams it stands forth as nature's proudest decoration. It arises from the black, boggy earth, standing boldly among the naked branches of a long-fallen Cedar or stretching above the marsh grasses that would veil it from the sun. Often it grows in abundance, making many splashes of scarlet where some narrow stream reaches the dense underbrush about the feet of towering Maples.

The Scented Water Lily has a fragrance that lingers in the memory and comes back with every thought of the shallow bays in the irregular lakes of the north. These flowers seem diminutive reproductions of big white Water Lilies, which the 
unappreciative pronounce odourless, in addition to having unfortunately missed their fleeting charm of fragrance. The leaves of the Scented Water Lily are small, round, and daintily cleft to the centre, and are never so abundant as to cover the surface of the water with a matted carpet of vegetation. The stems of the leaves are slender, and the eye delights in following their graceful yellow spirals through the still, clear water to the sandy ridges of the bottom. This quiet, almost retiring, sister of the Lilies seems to prefer the more remote waters where only the most ardent votaries of nature will seek her. It may be that she has been driven away from the haunts of civilisation by the destructive eagerness of the thoughtless to grasp and possess. 


\section{THE PASSING OF SUMMER}

Splashes of red, brown, and gold across the Maples, and the careless strewing of withered leaves that the trees seem still able to spare, mark the turning of the wheel of change. The suburban ravines have changed their decorative traceries in harmony with the passing season. The Asters and Golden-rods are coming to their kingdom, but nature never waits. Familiar nestling and shrunken leaves recall the earliest greetings of spring, but above them rise the tall, picturesque stalks of the Blue Lobelia, enriching the damp shades with their abundance of colour. Sometimes a stalk for no apparent reason will shade off even to a pale pink, but rich blue is the popular colour, the blossoms crowding with greater profusion as the tints grow richer and deeper. The Jewel-weed is shoulder high in the oozy, swampy hollows, rising in masses out of proportion to the extreme delicacy of its leaves and stems. The higher branches are still adorned with rich orange-yellow Cornucopias that wither almost as they are plucked, but the older seed pods are ready to snap and shrivel between inquisitive fingers, vindicating the popular name "Touch-menot." The white spikes of the Ladies' Tresses rise 
from the drier margins and banks. These modest members of the Orchid family were blossoming in June, encouraged by the warm dampness of unfrequented swamps. But in the marshy hollows and the drier soil of suburban ravines they choose a later season. The delicate white of their long, compact, and twisted spikes of flowers and the dainty perfume that is often lost in the blending of marsh odours give this flower a place among the favourites of advancing summer.

Blotches of white show where the Turtle-head is rising among the marsh grass. The lips of this flower always wear a broad smile, so quiet and complacent as to be positively irritating. There is a complacency that comes with a universal sympathy and understanding, with a perception of the beneficent relationship of all things mundane, a complacency that bears the bawling and the din, that walks calmly in the midst of disputations, that admits all philosophies. This is the complacency that sees one grand perfection in the myriad seeming antagonisms confusing and distracting the short-sighted-that waits on the working out of the law of existence a year, a century, a hundred centuries. It is manifested in the seer whose creed "invites no one, promises nothing, sits in calmness and light, is positive and composed, knows no discouragement."

There is also the complacency of the narrowly 
positive, who treat what they do not know as if it did not exist, who could manage perfectly if in the place of any one else, and can tell just what every one should do on all occasions. It is achieved by obliterating the sympathies and closing the eyes of understanding. It brings peace and satisfaction where it holds possession, all the peace and satisfaction that could there find a dwelling-place. Is it the universal or the narrow complacency that parts the white lips of the Turtle-head with a still, calm smile? The Evening Primrose bears a part in the season's scheme of decoration. The utility of its floral adornment is rather obvious, for it insists on crowding the large, coarse buds and seed pods about the slender-necked yellow flowers as they open to the settling clouds or the close of day. It is a pleasant surprise to see the tall, coarsely budded and weedy stem put forth a few graceful yellow flowers to enrich the evening air with a delicate perfume. These flowers do not survive the morning, but the bristling stalk has many in reserve and will continue to bring them forth night after night. That which in the sunlight seems the coarsest roadside weed has an evening beauty and fragrance awaiting the discerning. 


\section{THE WANING YEAR}

Summer's fullness is scarcely realised when the Sugar Maple flashes the signal of the passing year. Against the solid masses of varied green a bright splash of red glows unexpectedly in the sun, a reminder of perpetual change even in the richest abundance of growth. In the inspiring atmosphere of spring there is the spirit of evanescence. Hope and promise leave no room for thoughts of permanence and stability. But in the rich abundance of summer's meridian, when every tree is a bank of foliage, and the stroller wades through an entanglement of Sweet Clover, with promising Asters and Golden-rods, when every sluggish stream is stifled with Rushes or spread with a carpet of Water Lily leaves, when swamps and marshes are rich with luxuriant vegetation and breathe a warm odour of life and growth, when the familiar early flowers have given place to ripe or ripening berries and seeds, and nature's full fruition is all about, the longing hope of permanence steals on imperceptibly. The impatience of spring is gone, summer is at its best, and why should its perfection not endure? Long preparation has brought forth nature's masterpiece. Is there no pause for the 
enjoyment of its message? The question is mocked by the solitary limb that has stained its leaves with the brightest tints of autumn, and is ready to cast them to the first determined wind.

It is hard to avoid a twinge of regret at the unexpected reddening of the leaves. The Maple is generally first to give the warning, and the varied richness of its new colours does not atone for the loss of its contented uniformity. A single limb will sometimes take on the brilliant colouring of autumn, and stand out day after day, a bright splash on the varied greens of the background.

Where a lake, river, or open clearing exposes a stretch of natural forest, and Maples, Elms, and Beeches crowd up to the foreground, a branch here and there will take on the richest of colours, as if nature sought to warn the heedless world of an inhospitable time at hand. The Golden-rod may have given warning already by a few firm touches of bright pure colour on its rising fronds. The earlier Asters may also have held out at once a promise and a warning of the coming autumnal glory. The yellow trumpet of the Fox-glove may have blended another tint with the colours of the advancing season. But the distinctive flowers of autumn can never give the chilling warning that comes with the first brilliant markings in the foliage of the Maple. Sometimes a small tree that has stood modest and unnoticed among 
its more pretentious neighbours will glow forth in the misty morning completely arrayed in the bright colours of the passing year. If beauty is ever unwelcome, it is in the varied tints of the autumn leaves. But the feeling of rebellion passes in a moment. The chill is transitory. The portent of the change is forgotten in the infinite variety of tints and markings revealed on closer investigation. And with the momentary regret comes the sustaining thought that the falling of the leaves and the passing of the season's vegetation are but phases of the perpetual life in which nature renews her youth. "There is no death, what seems so is transition." 


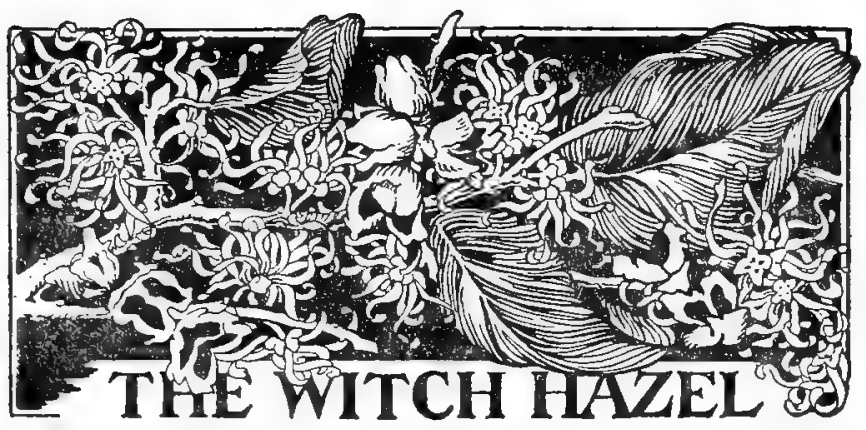

Nor in the human family alone does eccentricity win credit for unusual and transcendent talents. Innumerable trees and plants have for years imposed on a credulous and trusting world by means of peculiarities in dress and habits. Prescriptions of the present day are not like the medicine our mothers used to make. And when a nauseating remembrance of the horrible decoctions brings back the sinking, vacant sensations of early childhood, the thought that the ill-flavoured herbs were imposing on confiding motherhood by their eccentricities provokes a feeling of indignation. No wonder the present generation delights in exposing the pretences of alleged medicinal herbs whose reputations were sustained by unusual habits alone. The memory of catnip tea, wormwood, elecampane, senna, and other nauseating tastes on the sensitive palate of early childhood can never be effaced. And it is irritating to reflect that the faith of our good grandmothers had no foundation except I6I 
in the peculiar ways and manners of the herbs they gathered and prescribed.

The Witch Hazel, with its peculiar habit of bursting into flower after shedding its leaves in the fall, was naturally regarded as possessing unusual qualities. Any tree or shrub that could afford to so far ignore and disregard the established usages of the forest was confidingly credited with extraordinary powers. It is a shrub approaching the dignity of a tree, sometimes reaching a height of twenty feet, and is abundant wherever it has an opportunity in southern Ontario. Its rich, green, pear-shaped or oval leaves have wavy-toothed edges and are conspicuously though not quite evenly divided by a depression along the mid-rib. It bears some resemblance to the leaf of the Hazel, and that accounts for its name. People who see resemblances can never conceive of the amount of trouble and confusion chargeable to their account.

After the leaves fall the little globular buds which have been forming in clusters during the summer open suddenly into picturesque yellow flowers, each with four long, narrow, crumpling petals forming an irregular cross. Such handsome and striking adornment at so unusual a season has enabled the Witch Hazel to achieve a place of distinction. Its attributes are not only medicinal but esoteric. The Witch Hazel not only effects a wide range of wonderful 
cures, but reveals the location of subterranean springs and hidden treasures.

There are few counties in Ontario that cannot boast of a citizen qualified to work the divining rod, and, incidentally, if the expression may be extended, the people who contemplate the sinking of wells. A stout fork of Witch Hazel, shaped like a letter " A," still determines on many farms the place where the well is to be dug. The operator grasps the lower ends of the fork in his hands, and by twisting his wrists bends them outward till they are horizontal. It is difficult to hold a strong, springy fork in that position, especially when walking over uneven ground. And the esoteric influence of a subterranean spring, coupled with the elasticity of the wood and the tiring and weakening of the wrists, generally causes the point of the fork to twist downward. Where it turns the well is sunk, with perfect faith in the promised abundant flow of water. If the water is not found the turning of the rod is attributed to the proximity of mines or treasures, thus proving the overmastering and all-controlling power of faith. If the operator carelessly allows the fork to spring inward his nose is seriously endangered, and he may be rewarded with a flow of " purple tears."

Sometimes the Witch Hazel blossoms unusually early, and, although the leaves are still firm on the trees, the yellow decoration becomes conspicuous in 
many places. The strong, woody pods from last year's flowers mature beside the new flowers and soon they noisily open to eject small, nutlike seeds. This fusilade can be enjoyed beside the fire by placing a spray loaded with mature pods in a warm place. In a few minutes they will begin to pop open and eject the nutlets in all directions, sometimes with surprising force. But in the silence of the autumn woods, in the listening hush of falling leaves, this strange reproductive effort seems most impressive. When every tree and shrub seems saddened into silence by the slowly-dying year, when the withered leaves give back the strength and richness they borrowed from the earth, when the air is still with the moist chill of approaching winter, the snapping of a Witch Hazel pod, sending the twin seeds on their mission with the mystery of life, is a gladdening reminder of the perpetual activity that brings new life out of the year's decay. 


\section{5}

\section{THE TUSSOCK MOTH}

WE seldom admire the beauty of a creeping insect. The rich markings and glowing colours of Moths and Butterflies may be appreciated while they sail dizzily through the air or perch a moment among nectarladen flowers. But the creeping, crawling, leaf-eating thing, with feet that hook, and clasp, with bristly projections and abnormal rings and joints, is generally looked upon with aversion. A few weeks ago the Tussock Moths were crawling about with the timidity of a persecuted race. Their picturesque forms and gay contrasts of colour won no popular admiration. Their rich markings in red, black, yellow, and grey were chaste and delicate, even if they did present an unfinished appearance. There is no right way to stroke the Tussock Moth Caterpillar. His long horns and tail suggest the most repellent personage imaginable. The four diminutive paintbrushes rising from his back, and moving with every undulation of his lively, crawling body, seem an unnecessary decoration, and while they may help to win admiration they do not encourage familiarity. There are handsome but repellent bushy tufts of yellow hair along his sides, and these seem to 
harmonise with his delicate and brilliant markings. His head is a bright coral red, and there are dainty touches and spots of the same colour on his back. All these pretty and attractive patterns are combined on an energetic and voracious little creeper about an inch long, yet we generally admire it with our hands folded behind our backs. Animals and birds invite a caressing touch, but it requires the intimacy of a perfect understanding to handle with kindness the ephemeral representatives of the insect world, however beautiful they may be in form and colour.

These bristling and decorated larvæ have almost entirely disappeared, and some of them have reincarnated in forms strangely different and unrecognisable. During their six or eight weeks of active larval existence they crawled about and feasted on the leaves of the Horse-chestnut, their favourite tree. Though manifesting a strong preference, they do not entirely reject other foliage. As crawling is their only means of locomotion, they are not extensive travellers. A few drop from the branches to the ground, thus circumventing the schemes of those who would restrict them with metal bands and other devices. Others remain lazily in the tops of the trees, showing no inclination to travel. Wherever they go they are beset by parasites which lay eggs in their soft, tender flesh. These hatch into minute destructive larvæ that sap the vitality of the doomed protectors 
and providers. As the Tussocks devour the leaves of the shade trees, it is satisfactory to reflect that tiny parasites are devouring them. Only a few will survive to fulfil their life mission.

They grow by coming out of themselves - by casting off their outer covering, head, legs, plumes, and tufts of hair. From the inert larva thus cast off another emerges, with new head, legs, tufts, decorations, and markings, larger and brighter than the outer form that surrounded it. This change takes place two or three times during the few weeks of larval existence, and then the full-grown Caterpillars spin themselves grey, comfortable cocoons for the brief sleep of their pupal state. Some find a comfortable place in the cloth bands set about the trees to entrap them; but of the pupx thus collected and burned the great majority are already doomed to death by parasites-the little beneficial insects thus mistakenly destroyed. It is not in human affairs alone that we injure ourselves and our friends by the pursuit of our supposed enemies.

Some of the well-fed larvx are too indolent to descend the trees, and sleep in the upper branches, but the more adventurous make a limited migration from tree to tree. Females choose the trees which will supply food for their next season's brood, while the males, rejoicing in the prospect of winged flight, are satisfied with any crevice in a fence or wall. The 
pupal state lasts but a week or ten days. The great majority of them never awaken from it, but the parasites which have fed on them come forth in due time to attack the next brood. The females emerge helpless, wingless, fragile, and delicate, in no way resembling their former state of existence. They have no "new woman" proclivities, but seem content to live their lives on the little habitations in which they spent their brief period of rest. The males, equipped with handsome wings, fly gaily about during the few hours of their life as perfectly developed Moths. The females deposit their eggs on the woolly cocoons in which they slept, carefully covering them with a rough, white, waterproof coating. These coatings are conspicuous marks, and as each encases some two hundred or three hundred prospective larvæ they should be gathered and destroyed.

Many species of insects pass the long winter as inert pupæ. Some survive in the larva form and some in perfect development; but the Tussock Moth is of those which pass the winter in the egg state. Farther south they sometimes produce two broods in a season, but the white-coated egg masses appearing on the trees in the fall will not awaken to new life till next spring's leaves are spread for a feast. 


\section{EPIPACTIS VIRIDIFLORA}

Even in the world of flowers, rarity has a peculiar charm, and dull, insignificant, colourless blossoms may be the object of many a long and eager search. This erect but unassuming member of the Orchid family, not sufficiently familiar to enjoy a pet name, has appeared in the vicinity of Toronto, Syracuse, and Buffalo, but nowhere else on the continent. The weakness of prizing rarity for its own sake lends to every discovery a peculiar delight. This is enhanced by the attendant weakness of honouring the common and insignificant on account of distinguished family connections. The Orchid family must be accorded a place above all others in the floral world. The richest blooms of the tropics make the name distinguished and revered. Strange habits and ways, perching on trees, breathing nutriment from the air-all these tend to give the Orchid an honoured place and sometimes to surround it with an air of modern fashionable mystery. An indulgent public has even been treated to stories of wonderful extensions of the parasitic habit, and weird tales have drifted about of unfortunate travellers falling victims to the relentless tendrils of the devouring Orchid.

Naturally we respect and prize every member of 
so distinguished a family. Even in our own climate the title to distinction is upheld by the Yellow Moccasin Flower or Lady's Slipper of the shady woods and her more beautiful sisters of the Sphagnum swamps, also by the Showy Orchis, the dainty and delicate Calopogon, the Snake's Mouth, the Northern Calypso, and the white, stately, and fragrant Ladies' Tresses. And when the charm of rarity is added to the honour of distinguished connections the Epipactis becomes a treasured friend.

It was a great source of satisfaction to find a solitary plant growing in High Park beside the main drive of the ravine. It stood unostentatiously, scarcely more than a foot high, among some half-grown Elmleaved Goldenrod and Boneset. A dozen flowers tipped their rounded seed-pods along the stem above the leaves, but they seemed so inconspicuous and colourless as to be worth scarcely a passing glance. The mounted policeman was there, too, coming leisurely along the road, and the penetrating look of suspicion in his eye suggested an instinctive discernment of the proximity of hidden treasure. It seemed an age before he rounded the curve of the road, and even then he came back and looked over the Witchhazel bushes to assure himself that nothing was in danger. This flower has the three regular sepals peculiar to the Orchid, and also the three petals, two regular and one twisted and distorted. The twisted 
petal assumes a form strongly suggesting the Moccasin of her beautiful and distinguished sisters. This embryo Moccasin sometimes shows a suggestion of pink, but it is so small and the colour so mild that it lacks attractiveness. The Epipactis is distinguished from the other plain members of the family by the absence of a spur on the twisted petal and by a microscopic box and lid for holding the pollen.

There is a little depression running down the side of a steep, tree-covered hill by the Don valley where the Epipactis grows. This small, transverse ravine guides a rushing stream for a few days when the snow is melting in the spring and the absorbent earth is hard with frost, but all summer it is dry. Oak and Maple leaves gather in it farther up the bank, and these are gradually washed down in their slow return to the soil. On the southern slope just above the damp levels and under the open shade of a few small Hemlocks is the scattered bed of these rare Orchids. More than a dozen have opened their quiet, unattractive flowers and are ripening their oval seed pods. The first thought on discovering them is of the havoc that would ensue if the botanist found a clue to their whereabouts. But Orchids, like all the good things of life, are for those who appreciate. Ownership and possession are but trifling considerations, and they who have the appreciation should be satisfied without seeking more. 


\section{DEPARTING SUMMER VISITORS}

MANY feathered visitors that enlivened the spring with their ecstatic melodies have clothed themselves in quiet attire and are preparing for the southern migration. Some of the gayest are coming back from the north woods so modest and sombre that they seem almost saddened by the passing season. But their neutral shades are only a formal deference to the quietness of autumn, for the sprightly activity and eager delight of their transitory gatherings and momentary sociability reveal a full measure of the joy of living. The Scarlet Tanager, glowing with all his intensity of colour in early spring, so bright as to make a day memorable throughout the year, can scarcely be recognised in the timid, retiring bird of subdued and sombre markings, seemingly anxious to avoid attention till he can steal away under cover of night. The Bobolink that poised fluttering over the growing meadow in spring, showing a splendid contrast of glossy black with white and pale yellow, has also taken on the quiet tints and markings of his mate.

The shades, colours, and markings of birds are among the inviting problems. The struggle for 
existence all down the ages must lead to the survival of types and forms best suited to their special environments. Birds best adapted and equipped for catching fish or for opening seed pods will get most fish or most seeds, will grow strongest, and in the inevitable struggle will drive off the less fit. But whence the colours and markings that appear with such wonderful regularity in various species? Each feather in its place and order will show markings that blend together into a pattern, and all will be faithfully and minutely repeated in every specimen. It is a problem as deep as that of the "little flower of the crannied wall." The Tanager does not moult his brilliant colours and bring forth a covering more suited to the advancing season. His feathers have changed their colour with the passing of the spirit that found expression in the love song warbled from the high limb of a dead but defiant pine. The same feathers that glowed scarlet in the spring sunshine reflect only a dull, insignificant, yellowish green.

The most sociable and happy of our little transients is the Wild Canary or Thistle Bird, sometimes called the American Goldfinch. He seems quite as happy and glad as in the season of brilliant plumage and loud song. These little fellows are now hammering the seeds out of the Wild Sunflower heads and vigorously attacking the withered Asters. All seeds are acceptable, for they even pry open the cones 


\section{DEPARTING SUMMER VISITORS}

of the Birch and Pine, but the Thistle seems their favourite. - The Dandelion heads that still retain their seeds are eagerly torn open. In vacant fields, where the picturesque, blue rosette of the Chicory has been seen throughout the summer, they assemble in small flocks to gather the harvest. There they might easily be mistaken for English Sparrows, so quiet is their colouring. It seems unreal to identify that little industrious fellow, tearing out the dry seeds of the Chicory, with the brilliant songster, with black cap and wings and bright yellow jacket, perching on the Thistle heads in early summer. But draw near, and the whispered conversation of the little flock will reveal their identity. When startled they display the hurry and bustle of the city almost as eagerly as the Sparrows. But once in the upper air they assume their happy, undulating flight, fluttering up and gliding down on fanciful waves of atmosphere. They are indolent migrants, and do not hurry away, even at the approach of winter. In fact, they are indolent about all the important affairs of life, for they do not undertake their domestic duties till late in summer, when the more serious visitors have their fledglings out in the world. And that seems to be their way of solving the problem of perpetual happiness. Their flight is the abandonment of joy. Up and down they go, closing their wings after every spasmodic flutter and calling out in the exuberance of delight. 


\section{DEPARTING SUMMER VISITORS I75}

Their song suggests the tame Canary, less varied but more full of spirit, and like the familiar call of the Yellow Warbler, with a few concluding notes added to complete a happy measure. Whether they herald their arrival, linger over their departure, or remain throughout the winter, the wild Canary radiates a spirit of joy that is irresistible. 


\section{WHIP-POOR-WILL}

WHEN feathered holiday-makers are away in their crowded haunts and the remaining Warblers and Finches in sombre attire are making their dilatory way southward the insistent carol of a Whip-Poor-Will seems to arrest the retreat of the passing year. Close to the tent, with regular rhythm and unvarying interval, he sings away to the lonely night, without the inspiration of the many voices that answered him in spring and summer. A Screech-owl weirdly disturbs the repose of the woods, and the endless gurgling of the rapids is lost for a time in the long, expressionless call of the Loon. Frogs that boomed in resonant chorus from the long reach of the marsh are silenced by the chill of a late September night. The loud calls that make the interrupted silence more weird seem an inspiration from the wakeful moon struggling even to penetrate the dew-damp canvas roof, but the Whip-Poor-Will's note has a bright levity, suggesting the open day and the protracted summer in spite of its association with the lonely shades of evening. Other swift gleaners of the air have gone south, where insect activity is unceasing. The hardy sojourners of the arctic shores are making 
their way toward the tropics by long, silent night flights. Common summer residents have gathered their families together and departed. Yet this frail, delicate visitor of swift and silent flight not only lingers beyond his time, but fills the night with the melody of summer.

The Whip-Poor-Will is often heard but seldom seen, his retiring ways contrasting strongly with the conspicuous courses of the circling Night-hawk, to whom he is closely related. He sits and sings in the shade of the evening woods, always crouching lengthwise on his perch, his weak and tiny feet being incapable of supporting him in any other position. His white necktie is the only relief in his dull brown plumage, the fine and delicate markings of black and grey being generally invisible. When he darts silently after a passing insect the white on his outer tail feathers becomes conspicuous, and these marks distinguish him from his mate, whose equally dull plumage is relieved by light buff. He pursues his prey after the manner of the Kingbirds and other flycatchers, but there is no resonant snap when his enormous gape, with its imprisoning bristles, closes upon a Moth or Beetle. He returns swiftly and silently, not to a conspicuous and naked limb, like the Flycatchers of the open day, but to a shaded and sheltered branch, where the surrounding trees intensify the deepening gloom. The wait may be 
enlivened by a strain of rhythmic melody, but when his big black eye detects a tempting insect there is a swift and silent flight and a hurried return to his shaded perch. This lingering visitor of the northern woods will soon be forced by the disappearance of insect life to join his friends in the sultry warmth of the tropics. 


\section{BIRDS OF PASSAGE}

SPLASHES of yellow on the Maples and darkening red on the Oaks are the signals along the great aerial highway from the remote north. The broods of the season, grown to maturity in the close bounds of their habitations, nurtured and fed by attentive parents who did not travel more than a few yards from home, are now led and guided into a new and vast world in response to the signals of a changing landscape. In their long night flights the green and gold are indistinguishable, and they see only the alternating of land and water, with the feeble reaching up of lights from the spots where restless humanity congregates. But during the daily rest they hurry among the changing and leisurely falling leaves of the tall trees or settle down under the bright red feathers of the Sumach, where the poison ivy in tints of flame seeks to redeem its evil reputation.

White Throats in large numbers are passing over, about, and through the city, busily gathering daily supplies among the falling leaves. Some have the three white lines on their heads clearly distinct, while others show only a tawny promise of white in the advancing season. All show the distinguishing white throat and the eager, coy activity that gives them a 
place among nature's successes. Myrtle Warblers, first in the northward migration in spring, are leading their numerous relatives toward the land of perpetual summer. The bright yellow rump is their conspicuous mark, the same colour on the crown and sides of the breast being more difficult to discern. In an unending hurry they gather minute insects from limbs and twigs, preferring to glean among the Willows and Rushes in the marsh. Some of the most enterprising imitate Flycatchers by darting out and capturing passing insects on the wing. The Warblers will soon be passing in large numbers from their northern nesting grounds. There they were protected from invasion by the insect life on which they feed. In a double sense they owe their preservation to the Mosquitoes and black flies. Small size and fondness for inaccessible regions both north and south also help to save the Warblers from destruction and avert the danger occasioned by their strikingly beautiful plumage.

Golden-crowned Kinglets are gathering sociably in flocks. Although the smallest of our birds, with the exception of the Humming-birds, their activity and flaming crests always attract attention. Their short, whispered notes are generally the first indication of their presence, but they are not averse to working freely under inspection. Though making a distinct migration, a few remain throughout the 
winter. They are not at all disturbed by the cold, and their thin notes are often the only indications of life in the close Cedars and among the tall, naked branches of the Elms and Maples. The first arrivals will probably move farther south, but there are plenty in the northern woods to continue their whispered conversation in the changing foliage. A few Robins still linger about, but they have assumed the serious air of the advancing season. Should one be tempted by the unusual warmth to indulge in the liquid song of spring there is no response, and he soon desists, as if ashamed of his innocent mistake. The harsh voice of the Jay is made more conspicuous in the silence that seems to settle down with the falling leaves. The Crow, too, is calling. Both these hardy and noisy marauders will be content to remain throughout the winter. The blue sky, where recently the Swifts and Swallows darted after insect prey, seems to feel their absence. Solitary Herring Gulls pass from the inland waters to the increasing flocks on the lake, and toward the horizon a steady moving train of dots on the sky shows that the ducks are assembling for the long migration. The silent eagerness of passing flocks contrasts with the loud awakening songs of the year's morning, but the season of silent desertion is a bridge from spring to spring, and an earnest of the renewal of nature's perpetual youth. 


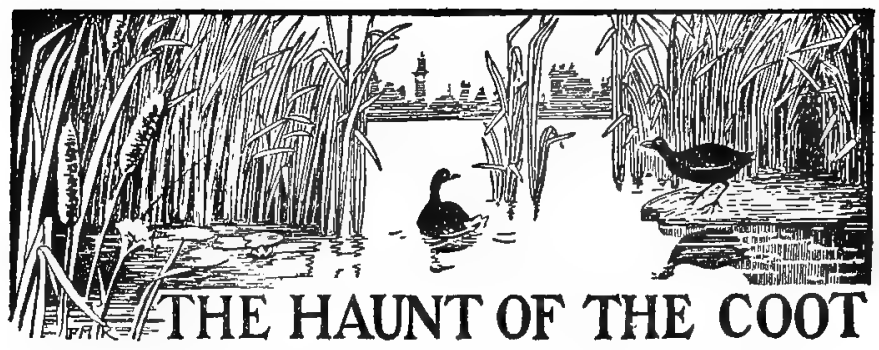

AGGRESSIVE and inconsiderate human encroachment does not seem to have robbed the city marsh of its popularity as a place for assembling and organising the southward journey. Swallows have gathered and departed. The Plovers and Sandpipers have followed in spite of the attacks that left them with depleted numbers. Blackbirds are gathering, but the most active sojourners are a few broods of Coots hiding in the sheltering banks of Rushes and sometimes freely feeding in the open water. The Coot is the largest of the birds that spend the summer hiding in the Rushes and swimming about over the clogged and weedy marsh. It has the large body and small head of its less conspicuous relatives, and its white bill and wing bar distinguish it from the Florida Gallinule, both being familiarly and fittingly known as Mud Hens. Banks of dense Rushes, where both wading and canoeing are impossible, afford the Coots a comfortable home and safe retreat. They still nest in the marsh occasionally, regardless of the city's encroaching population, and it is not till the inevitable I82 
fire removes the sheltering Rushes and the ice makes all places easy of access that the habitations of the previous summer are disclosed. The nests are large and loosely woven in the half-solid banks of Rushes. They show where families have been reared in easy disregard of passing boats on the open water and pedestrians on the solid ground.

The hiders are generally noisy, and their uproar seems more in derision than alarm when curious eyes seek in vain for the source of their varied clucks, calls, and chatters. Coots make a good appearance in the open water, where they move with heads elevated after the manner of the Grebes. As their long toes are equipped with scalloped lobes, they are good swimmers, and they can also dive well if pursued where no friendly sheltering Rushes are available. They fly only when obliged to, but after the first trailing efforts they make good speed. In steady flight their stroke and outline suggest the Duck, but their long legs cannot be gathered up out of sight. Against the dark-green background of the Rushes or out over the open water their dark slaty plumage seems black as night, but strong sunlight brings out the lighter shades. The Coots seem quite reasonable in their migrations, following the opening season northward and nesting freely throughout their range. There is no eager quest of the arctic or the far south. They locate on the marshes and sloughs, where shelter is 


\section{THE HAUNT OF THE COOT}

secure and aquatic life supplies abundance of food. The new broods join in the southern migration when the first chills of night give a reminder of incessant change. Some morning a quiet marsh will be transformed into a scene of animation by the arrivals of the previous night. Close to the ready shelter of the Rushes, they swim contentedly about, darting their short, sharp bills here and there among the floating weeds and gathering the clinging snails and other forms of aquatic life. Familiarity is resented by a dignified and almost leisurely retirement into the safe shelter. After a few days of loitering and recuperation an evening of activity is followed by a morning of silence. The deserted marsh seems expressive in loneliness. It tells of a long journey in the impenetrable darkness of the night sky, where the secret way that baffled the prophet of old still eludes man's insatiable curiosity. 


\section{A LONELY WANDERER}

THERE is a weird fascination in the full, round moon when the moving dome of hurrying clouds gives the silent orb the deceptive aspect of intrepid speed. It seems to be driving through the crowding masses of floating vapour that hurriedly disappear in the uncertain light of the close horizon. It makes its swift and luminous way, hiding a moment behind a dense mass of impenetrable white, peering resolutely through the more transparent fleeces of vapour, and sailing out freely across the open spaces of clear night sky. The illusion of a swiftly careering moon in the great festooned dome seems as real as the sensation of speed when forgetfully watching the steady flow of a hurrying river. Such a night was fixed in memory by a lofty wanderer. The passing clouds were so fine and fleecy that the light of the great white globe was undimmed. With the easy persistence of open day it sought out even the shadows and recesses, making all artificial illuminations seem weak and helpless by contrast. Clouds, too attenuated to unfold their shadows, moved steadily from the north, assuming a circle of dainty rainbow tint around the white globe that peered 
steadily through them. Orange was most persistent in this prismatic circle, and it faded out imperceptibly into yellow. Each passing cloud took up the circle of delicate, transparent colour, holding it around the moon with the accuracy and precision of light's established ways. With each momentary clearing of the sky all colour was lost in the clear white light from the furrowed face of the glowing satellite. Then another transparent cloud took up the tint of the outer circle of colour, the fading yellow of the uncertain circumference holding its rich gradations to the almost invisible blue close to the inner ring of light.

On such nights in autumn a field-glass sometimes reveals the small migrants trailing their lofty course southward across the moon's disk, but it was a surprise to see a large Hawk making its steady way over the city toward the west at midnight, moving quite low, and its steady course could be followed after it had passed the circle of light and colour. These birds of prey are uncertain in size and colour, but they have distinct family characteristics. It was probably a Red-shouldered Hawk or a Red-tailed Hawk, but colours and markings were lost in the black outline against the moon's light. It did not seem large enough for a Goshawk, the predatory bird that brings the family into disrepute, but size and distance are uncertain on the brightest night when the horizon 


\section{A LONELY WANDERER}

crowds down and every moving object passes quickly from view. A few steady strokes and the lonely wanderer was lost in the low, moving clouds. He may have been tempted by the brightness of the moonlight to cross the city, where feeble lights reached helplessly upward in the great glow. Such an apparition tempts a long vigil, but the bright and steady effulgence that passed the zenith and followed the lead of Mars and Saturn toward the west was not again animated by a passing migrant. 
I88

\section{THE AUTUMN PANORAMA}

IN a blaze of glory the growing season is passing away, and the returning tints of autumn make the suburban ravines as attractive as in spring. The moist warmth that settles down among the half-denuded trees seems filled with the spirit of completeness and satisfaction. The crisp rustle of fallen leaves underfoot becomes a whispered story of transition. There is a noisy felicity in pushing the feet through the gathered heaps under the Maples and scattering them about. It seems a protest against the ever-insistent spirit of sadness that comes with the passing of the year, and will not be thrown off. At every point the passing panorama presents a new scene. Against the rising hill is a dark Cedar, with Virginia Creepers twined around it, contrasting their vivid red with its deep green. Beyond is a bare stretch of hillside, with just a few trees at the top-sentinel Pinesand, towering gaunt and skeleton-like above them, the bare and blackened trunks of their long-dead progenitors. Below is the bright Sumach and the more sombre tints of denser shrubs and bushes. The Beeches are half-denuded, and the picturesque outlines of their smooth grey trunks and branches stand out distinctly in the new landscape. 
This is a good beechnut season, and the satisfaction of gathering and eating a few plump triangular nuts is a proof that man was intended to satisfy his own wants. The finest products of tropical countries can never give the same satisfaction as the beechnuts gathered from among the leaves with our own eager fingers, or plucked from the branches after a laborious climb. The Wild Plum hidden in the woods, the Mandrake, the Ground Cherry, the Choke Cherry, all have charms above the finest fruit of the orchard to those who know their haunts and seek them in their seasons. A gardener may supply Mushrooms at any season, but he cannot give the relish that comes from gathering them in the grey, misty twilight, when the lingering dew forms in crystal globes in the sunken leaves and delineates every thread in the cobwebs on the grass. And when the double report of a shotgun comes over from the marsh we must temper our condemnation of the cruel, killing propensity with thoughts of the tempting satisfaction of winning food from reluctant nature. The real enjoyment of a Blue-bill or Whistle-wing is known only to those who have seen it careen over the decoys.

Squirrels take special delight in mocking other Beechnut gatherers. They scatter the shrunken, unfilled nuts all about, and leer from the upper branches at the disappointment of the bipeds under the trees. Plump, full nuts they never throw down, 
although they strew the thin shells liberally among the leaves to show that the harvest is abundant. The Beech shelters those odd, interesting parasites, the Beech Drops, supposed to draw nourishment from its roots. Their flesh-coloured, leafless stems are about a foot high and are studded with insignificant flowers. We demand conformity in the vegetable world as elsewhere, and when a plant grows without leaves and has flowers that do not open it is naturally regarded with suspicious aversion. Although the Beech drops are abundant and are looked for under every Beech tree, still they are not free from the eerie significance attaching to the Corpse plant and the Cancer root. These seem to suggest a parasitic unwholesome life, in contrast to the glorious death of the broad valley and rising hill, where autumn, with her Midas touch, is turning the world to gold. 


\section{THE DEAD LEAVES FALL}

Although the half-denuded woods are dampened with a drizzling autumn rain, and the mingled yellows, browns, and reds of the discarded leaves are blending in a soft, damp carpet of neutral shade, it is a happy thing to be abroad, where the pilgrims from the northern woods loiter a moment in their long migration. The White-throat is making his way southward and seems quite discouraged at the state of the weather. But the Nuthatches, creeping up and down the rough Oak trees, are as bright and energetic as in summer. Birds are privileged of nature. They can wear the most brilliant, rich, and glowing colours without being vulgar, and can give way to ceaseless industry without being offensive. Where the dry side of a comfortable Oak makes an inviting shelter it is pleasant to lean and watch the silent activity of the little fellows as they search in the rough depressions and probe for insects with their long bills. Against the grey bark on the dry side of a Beech the Nuthatch becomes almost invisible. But he is too active to be hid, and his continuous motion stirs the atmosphere of life in the silent dampness of the dripping woods. He hops around to the wet side of the Beech, showing 
grey against a background of black. That is uncomfortable and apparently fruitless. Now he peeps out from behind an Elm, so close that the round of his bright, black eye can be clearly discerned. He moves around out of sight, hides a moment, then flits away behind a dense clump of Cedars. Again the damp stillness settles down. It is strange how the departure of such a tiny atom of life could have made such a change.

A pea gall drops from a clinging leaf high amongst the thinning branches and rolls over the wet ground. The tiny insect that has constructed for itself this little spherical habitation at the expense of the oak leaf is prepared for a long hybernation. It will lie among the fallen leaves all winter and will not respond to the returning warmth of spring. Then its pea-like habitation will have lost its fresh colour, but will still contain the microscopic spark of life. It will thus inertly survive the summer and the succeeding winter, to come forth on the following spring, mingling with the myriad insect life of the woods.

The young hemlocks spread out like umbrellas, making convenient resting-places during the intermittent showers. In the darkest shade the matted twigs and needles bear the record of a forest tragedy. Tiny feathers are scattered about, tail and wing quills, and lighter airy down that can scarcely be 
united. A weasel would not have devoured the body so completely, and it has been evidently the work of a vagrant cat. The bill and long tongue, with a few clinging feathers, are left as if for purposes of identification, and these, with the gathered quills and lighter remnants, tell that the victim was an oven bird. The cautious, retiring nature that chose the low shrubbery and escaped the floberts and catapults throughout the summer betrayed the little fellow to his fate in the fall. In spring the woods resounded to his ecstatic melody. Now there are only a few scattered feathers to record the diminutive tragedy of his end. In the records that strew the woods, perpetually recurring and perpetually covered up, we see the unfolding of nature's plan. Next spring the loud repeated call of the Oven-bird will resound through the renewed shrubbery, and in autumn the prowling vagrant will stalk its silent victim. 


\section{WEATHER PROPHETS}

THE odour of burning leaves is in the air. There is a natural freshness about it that prompts the expansion of the lungs. It seems an assurance of a wave of real air in the midst of the sulphurous fumes of a thousand chimneys and the penetrating dust of the abraded streets. The smoke of the leaves seems but a strengthening of the natural leafy smell that fills the naked woods, where the scattered foliage is returning again to the earth to enrich it for a new season's growth. There is no more satisfying forest odour than the exhalations from the fallen leaves, when they spread the moist, misty warmth of Indian summer among the rugged trunks and naked shrubbery. They seem to give forth again the breath of life that made the spring an invitation. The season is so complete that the active preparations of the Muskrats in the marsh become almost annoying in their persistent suggestions of coming change. Smoke arises from the marsh and hangs in the still atmosphere, showing that the natural processes of decay are helped by juvenile destructiveness. Primitive man worshipped fire, and the spell has never been thrown off through centuries of civilisa- 
tion. We still stand and gaze, fascinated by its glare or lulled into dreamy forgetfulness by its easy, ceaseless, evanescent transformations. But some one may be overtaken with a visitation for the idolatry of the little fire-worshippers who are burning the dry rushes in the marsh.

The active weather prophets who are putting up their dark warning signals in the deep margins of the open water or among the half-submerged banks of rushes have no reason to fear, as the soaked vegetation with which they build is perfectly fire-proof. They have a great reputation for forecasting the weather, and have managed to sustain it all down the years. The man in doubt as to the nature of the coming winter still turns to the Muskrats for advice, and if their forecasts do not prove accurate they at least put his mind at rest for a time and supply him with a definite policy for root cellars and embankments. With perfect confidence the fork handle is thrust into the water beside the Muskrat house, and the depth is accepted as an accurate indication of the severity of the coming winter. If the winter is to be very cold the Muskrat knows all about it, and selects deep water so that the frost will not interfere with his tunnelling operations. That Muskrat estimates vary does not weaken popular faith or confidence. Their reputation rests on the invariable longevity of a successful prediction and the ephemeral life of all 
mistakes. The dark brown houses rising from the water or displaying their irregular domes among the withered Rushes show all kinds of estimates for the coming winter. Some of the builders have chosen a deep spot, or, more probably, the top of a steep mound rising close to the surface and giving the impression of a house in deep water. Some have chosen the shallow marshes, and others have built on the shore, with the certainty of tunnelling through frozen ground. Out of so many different predictions some will certainly be verified, and they will be recalled to sustain the reputation of the Muskrat as a weather prophet.

Chickadees predict severe weather by their abundance. All who admire their nimble, acrobatic manceuvres as they search the twigs for food, or who enjoy their sociable notes as they keep in touch with their companions, do not necessarily share the common faith in their ability to foretell the weather. A more noteworthy visitor from the remote north is the Purple or Pine Grosbeak. He seldom ventures so far south except in the coldest winters, and sometimes he will let several years pass without paying us a visit. This year a number of Grosbeaks have already been seen in and about Toronto. They may be hunting for the typical Canadian winter and unable to locate it. They are almost as large as Robins, but shorter and apparently stouter, the forked tail and 


\section{WEATHER PROPHETS}

stout, conical bill being obvious distinguishing marks. The male shows a uniform rich purple on head, back, and breast, shading to dark slaty grey on wings and tail, while the female is generally sombre, with a washing of olive yellow on the breast and upper tail covert. A pair were seen a week ago in the Humber valley as attentive and sociable as Robins in spring, but most of the visitors are in small, irregular flocks, feasting greedily on the Mountain Ash berries, of which they eat only the seeds. All who have faith in their prophetic insight will look for the unusually severe winter foretold by their early southern migration, and if the prediction is verified it will be many times recalled. 


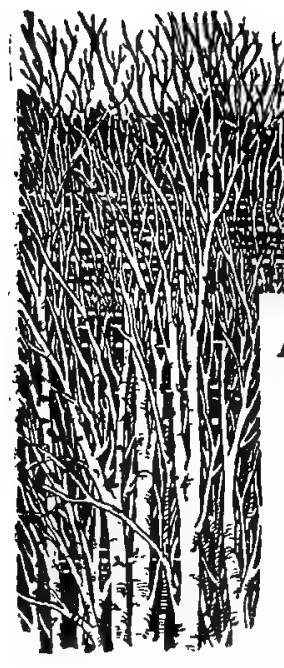

\section{AS THE YEAR PASSES}

THE crisp rustle of the leaves grows more pleasing as the brown transitory covering deepens in the hollows and yields to the caprices of vagrant winds. Where the Red Maple still displays its foliage it is the most brilliant of forest trees. Every leaf has a special design in crimson, yellow, and green. Some are daintily tipped with the richest hues, others vary their brilliant reds with a tracery of pale yellow and surviving green, while others show a uniform richness of colour in every vein and fibre. When the sun looks through and the wind pulls at the clinging foliage the masses of colour glow and gleam in vivid intensity. Oaks still cling to their rich and varied foliage, and seem scarcely to miss their generous contribution to the crisp covering on the ground. They like to retain their leaves, and often a brown bunch will remain here and there throughout the winter, gathering a transient covering of snow from every storm. In this they show a sympathy with some of their 
evergreen relatives in the south. Branches stand out in more distinct outline as leaves are cast aside. The Silver Birches are almost disrobed, and their clear, graceful outlines lend distinction to the changing landscape. Cedars, Spruces, and Hemlocks in their perennial green become conspicuous in the fading and disappearing foliage. Dense banks and masses of verdure that blended with the surrounding woods in the fullness of summer now stand out distinctly among the half-denuded branches, and their shelter invites the loitering feathered visitors on their southern migration.

The Bluebind is making a passing visit, and his vaice has assumed the conversational tones of autumn. It is so different from his familiar call in spring, but seems to suit the passing mood and season. A sad year is recalled when the Bluebirds mysteriously disappeared. Their friends missed them from the orchards, gardens, and shade trees, where they had long been so familiar. Nothing had occurred to account for their strange absence. Spring did not seem like spring at all when not heralded by the Bluebird's cheering note, and the swelling buds and opening leaves seemed to lack the element of life familiarly supplied by his bright colours and happy energy. There was no news of a disaster to the flock during its wide winter migration, but the Bluebird's friends (and every bird has its friends) were filled 
with anxiety regarding his fate. Spring came without his cheering call, and autumn passed without his sociable activity. The next year was awaited with anxiety, and the few eager announcements of actual visits left the balance even between expectancy and disappointment. Now our happy friend is as familiar as ever, and his bright blue coat and dark red breast are conspicuous among the leafless branches as he lingers on his southern journey. The harsh voice of the Jay calls a visitor to admire his beautiful display of blue and white. He is a happy fellow, quite content with the fare provided by the bleak woods throughout the winter. The White Throat is among the most interesting of the passing migrants-so full of song that his music may overflow at any time, even in the night. It sings away the days in its southern home when other birds are silent, but has a wealth of spirit in reserve for his love song in the northern woods. Though many of the passing visitors lack the bright plumage and inspiring songs of spring, there is a warm sociability in their transient gatherings and a confident familiarity that seem a compensation for the vanished youth of the year. 


\section{PREPARING FOR SPRING}

WHERE the Sedges wilt and wither, exposing the hard, frozen earth, and where the leaves have been soaked with the rain or carried away by the searching winds, the elaborate preparations for a new season are freely revealed. The Wintergreen pays no attention to the penetrating frosts that congeal the moist earth about its roots and solidify the lingering foliage of many of its forest neighbours. Its scarlet and green, its mild flavour and pleasant aroma remain as in summer. But in the open spaces the artistic rosettes of fresh leaves show a thoughtful regard for the coming season of repose. The Evening Primrose spreads a most handsome circle of pale green leaves, in no way suggesting the tall, irregularly podded stalk and perfumed yellow flowers of summer. The slenderwaisted and pointed leaves radiate from the deep, fleshy root, making a circle sometimes a foot in diameter. Each circle of leaves grows regularly shorter, and there is a cluster of points in the centre, the whole rosette lying flat and even on the ground, prepared to sleep under the white coverlet till spring. These recumbent circles of pointed leaves are among the most decorative preparations for the season to 
come. They lend a charm even to the frozen ground by their symmetrical outlines and torpid promise of renewed life. In spring they will speedily wither as the strong, coarse stalk rises from the ground. Some of the outer points of the circles are already turning brown.

There are other decorative rosettes nestling close on the hard, frozen surface. The Viper's Bugloss, branded by an unsympathetic community as a noxious weed, in spite of the bright picturesque aspect of its blue, bristling spikes of flowers, appears like dark green stars under the withered grass and sedges. Its coarser and bristling texture distinguishes it from the evening primrose. In summer it displays a decorative scheme peculiarly its own, coarsely picturesque, with unfolding spikes of small blue tubular flowers relieved by pink buds and red protruding stamens. The best time to study the wild flowers is all the year round. The Shepherd's Purse, more conspicuous as a weed than as a flower, now takes on a fine rosette form and lies close to the ground, its deeply-lobed leaves in a less regular circle presenting an excellent decorative effect. In summer its little, two-lobed, purse-like seed pods will be more conspicuous than its diminutive white flowers. Just now it is at its best. The Saxifrage spreads a little irregular bunch of leaves on the ground, seeming eager for a chance to hide away under the snow. 


\section{PREPARING FOR SPRING}

These leafy circles appear like hopeful claims staked out for flowering spaces in the spring. The treasure located there is the mystery of life. "In dark soil and the silence of the seeds the robe of spring it weaves." Where it is not sustained in the vigorous evergreens, the surviving circles of leaves, or the hidden roots that endure the winter, it lives in the inert seeds that have been scattered and hidden in bewildering variety in every crack and wrinkle of the receptive earth. It seems strange that every foot of that solidly-frozen surface is instinct with life, dormant for the moment, but ready to renew its infinitude of activities with the changing seasons. 


\section{EARLY WINTER}

THE cold quiet of the suburban woods intensifies the charms of solitude. The life that shrank timidly away from strollers and revellers in summer comes forth with confiding indifference. The lone invader is treated as a friend, no more dangerous than the distorted roots that afford a comfortable resting-place. In such silence the mild tapping of a Downy Woodpecker is a distinct and insistent disturbance. This little fellow in boldly mottled black and white is one of the most friendly perennial residents. He flits from tree to tree, ignoring visitors, clinging to the bark and using his tail for a support, chipping off the bored and tunneled covering and reaching his long, barbed tongue after the hiding grubs and beetles. When near, the scarlet crescent on his head shows quite distinctly. It is an ornament which his mate does not wear. Like most devotees to excessive activity, he lacks thoroughness. A few taps here and there, a cursory inspection while hurriedly hopping for a few feet on the bark, and a tree is abandoned for another adjacent. Thus as each tree furnishes its morsel the quest goes on, never relieved by the discovery of food in easy abundance. The Chickadee is another 
confiding friend of winter, never failing to welcome a visitor. He announces himself and his small party by a distinctive note, but does not pause in his search among the twigs and buds. He is more thorough than the Woodpeckers, and will deliberately swing under a twig to reach secreted insects. This performance often reveals his identity when in a naked tree-top outlined against the sky. When familiarly near his black hood and light breast, touched with colour on the sides, are distinctive marks.

The Nuthatch is a silent friend in the winter woods, neither tapping like the Woodpeckers nor calling like the Chickadees. His short tail, slaty-blue mantle, and black cap distinguish him from the Woodpeckers as he clings to the bark, searching its rough intricacies for food. He is far more nimble on the bark than the Woodpeckers, and can cling or descend with head downward, a feat no other bird can perform. The brightness of the day encourages unusual activity, and the life of the woods seems multiplied by frequent passing and repassing. Another friend, the smallest and brightest of all, has made his silent way unseen until he returns the stare in roundeyed surprise from a branch a few feet away. This is a Golden-crowned Kinglet, and she bows low as if to display her rich and contrasted band of yellow. Her mate is still more brilliant, having the yellow intensified to red in the centre of his crown. Her plain olive 
mantle makes the gay patch of colour seem more intense as she pursues the quest of small insects among the buds. With the exception of the airy, sunny Humming-birds, the Kinglets are the smallest of our feathered visitors, yet the Golden-crown can secure an easy living through the winter, and seems to enjoy every day of its cold silence. From this timid speck of living, restless beauty the eye is almost rudely called by the hurried passing of a big shadow as a Red-shouldered Hawk curves silently among the trees to a conspicuously low perch in the crowded Maples. One glance destroys his easy confidence, for he has scarcely alighted when he makes a hurried spring into the air, pursuing his devious way out of sight among the trees with evident haste and fear. The alarmed retreat of this suspected and suspicious bird breaks in rudely on the happy equanimity of a winter scene from the versatile drama of bird life. 


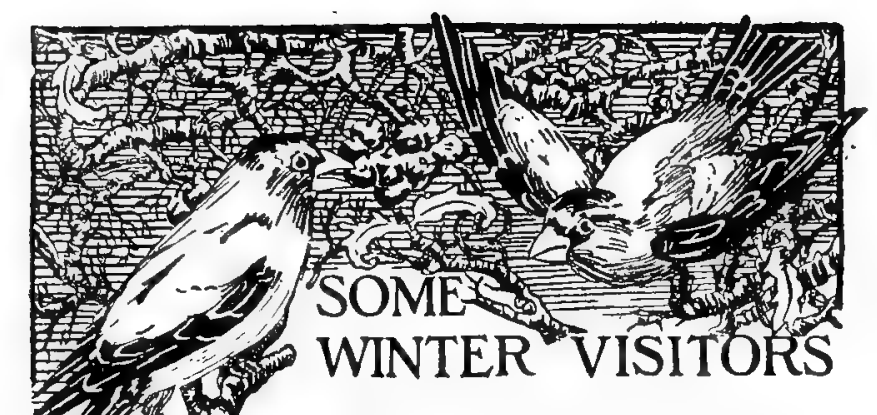

ADVANCING winter is shifting the scenes in the active panorama of outdoor life. Along the shore, among the naked branches, in the suburban ravines, over the frozen ground, and through the withered remains of the summer's vegetation is the busy energy of feathered visitors from the north. The hurried fluttering of their wings seems a faint protest against the impressive silence of the snow. In their cheerful disregard for the severity of the season, their bright communal fellowship, and spontaneous energy, there is compensation for the vanished romance of the spring and the domestic life of full, round summer. All birds break into melody in spring, when the very atmosphere is a song and all nature is pervaded with the spirit of new life. But the little visitors who can be bright, cheerful, and entirely alive through the bleak winter, as they gather the seeds of the withered Golden-rod and Sweet Clover, have a message for humanity distinctively their own. 
The little Redpolls are here, manœuvring in comfortable flocks along the lake shore. They seem scarcely able to remain still long enough to gather a few clinging or scattered seeds. The quiet, cold monotony of a sportsman's wait for a flock of Bluebills is suddenly broken by the fluttering of little wings. The Redpolls have come out of nowhere. The flock darts hither and thither in an inextricable entanglement of changes, and settles into sudden stillness on an adjacent clump of scrub Willows. But the stillness is only apparent, for their intricate activity on the wing has been changed to a bright restlessness among the concealing twigs near the ground. They are apparently as modest in attire as the Sparrows, for their purple-red crowns are scarcely visible on account of their unceasing motion. The males have also a scarcely noticeable pink tint on their breasts. The light wing bar, forked tail, and sharp, conical bill are distinctive features. Little flocks rise as suddenly as they alighted, turn this way and that in mixed unanimity, and scurry away as if an adverse fate impended over the hindmost.

Snowbirds are careening along the shore, always as joyful as children released from school. Hither and thither, up and down, intoxicated by the joy of aimless flight, the passing flock are intermingling with bewildering irregularity. Suddenly they execute a turning movement, mixing up and fluttering down 
in the greatest imaginable contrast to the well-drilled flocks of Plover that sailed along the shore two months ago. On the snow-sprinkled sand among the dead weeds the Snowbird, with his profusion of white and pale brown, becomes almost invisible. He walks about quickly, but with a serious gait, sometimes shaking the seeds from a withered pod, but generally directing his attention to the ground. He moves rapidly away if any familiarity is manifested. The rise of the flock is as sudden as its descent. Where only two or three could be seen walking about, a score rise in the air, flitting up and down along the shore as aimlessly as the inanimate snowflakes carried past by the wind.

The Grosbeak came early and is making a long visit, so long that he is losing his innocent confidence in humanity. His trust has been so often abused that he is growing suspicious, although he still prefers the crowded city to the suburban woods. There is no more leisurely and indulgent feaster than the Grosbeak, and the way he regales himself on the seeds of the Mountain-ash berries and small Crab-apples without wiping his bill or regarding the cleanliness of his feathers shows that the privations of his northern home have cultivated $\lambda$ demoralising appetite. It is hard to watch a Grosbeak on a Mountain-ash tree for half an hour and retain a sincere respect for him. But all the northern visitors are 


\section{SO SOME WINTER VISITORS}

welcome in the winter season, whether they deliberately feast and fatten on good things denied them in their distant home, showing the steady joy of persistent selfishness, or flit about like glad, inspiring spirits of the frosty air, filling the wintry world with their spontaneous joy. 


\section{WINTER BUDS}

WHEN the cold, steady north wind of autumn comes down with the oppressive sweetness of a dirge, and the withered leaves are torn away and hurried along to their unknown lodgments in the furrowed ground, it may soften the tragedy of their passing to reflect that each leaf has been pushed aside and crowded off in the active preparations of its coming successor. Secure in all the protected angles, where the leaf stems joined the twigs and smaller branches, the little buds have been growing, carefully enclosing in their diminutive forms an infinite variety of leaves and flowers. That a tiny bud not as large as a pea can contain a perfectly formed bunch of flowers enfolded in equally perfect leaves is a revelation of nature's strange, resourceful ways. There are buds holding only a single leaf or flower, others with only a male or a female flower, still others with both leaves and flowers enfolded together, perfect in their microscopic development. Here and there in late autumn a few lonely leaves will be found partly withered but still clinging to a twig or branch. If they are examined it will be found that for some reason the little buds that were to crowd them off have failed to develop, while all about the scars where other leaves have clung are almost covered by the little thatched habitations of next season's foliage. 
The Beech is among the finest trees in winter. Its smooth, grey, clean-looking trunk stands out almost as distinct as the Silver-birch, and its sturdy aspect is sustained through a ruggedly symmetrical expansion of grey branches, the entire outline touched with the delicate reddish brown of the finely-encased foliage. The buds are long, smooth, and so finely pointed as to seem like formidable thorns, and throughout the winter there is an earnest of life in their rich, warm tints. Most of the buds are terminal on the small twigs, but occasionally a lateral bud standing out at an abrupt angle gives variety to a graceful spray. These buds contain, carefully folded, the diminutive, downy leaves, ready for the coming season. The lighter markings of their overlapping scales give promise of the familiar elongation of spring, when the life within breaks through the inert covering, and clothes the tree once more in rich waves of green. On the higher branches are some shorter buds, which will open at the same time to shed their fertilising pollen, and still other buds, scarcely distinguishable, till they expand as fertile flowers and yield for the squirrels an ever-abundant feast of Beech nuts.

The Soft Maple buds are round, and so closely clustered as to be quite conspicuous and suggestive of premature development. But the Maple is one of the trees that can wait. The flower buds will open first and strew the ground with scales, and the male 
flowers will fall before the leaf buds open. On the Sugar Maple each terminal bud contains not only a bunch of flowers, but several pairs of leaves folded about them, the whole encased in compact scales and thus securely guarded against the winter's frosts. On the sides of the twigs the more elongated buds hold several pairs of leaves, and those more oval in form hold bunches of flowers, to droop as they develop and bring forth their familiar two-winged seeds.

The Silver Birch can rank with the Beech in the delicate tracery of its budded sprays, and its aspiring trunk is conspictuous even against a background of snow. Some of last year's empty seed cones are always retained, and the male catkins for the coming year, almost an inch in length, appear in conspicuous bunches at the ends of the higher twigs. These developed during the summer, but will remain quiescent till next spring, when they will droop and elongate, shedding their yellow pollen to the passing wind. The fertile catkins are still snugly folded in the rounded buds, ready to come forth with the leaves in spring. The leaf buds are abundant and conspicuous along the finer twigs. Each holds a pair of enfolded leaves safely guarded from the winter and awaiting the life-giving touch of spring. It is easily natural to forget the passing of last year's life and vigour in contemplating the new growth that fulfills the perpetual law of succession. The death of the past is essential to the life of the present. 


\section{BITTERSWEET}

ThIS robust and sturdy climber gives the most cheering manifestation of life and vigour in the winter woods. Its bright scarlet and orange berries, with their three-lobed pods standing carelessly open, are indifferent to rain, snow, and frost. They do not resent the importunities of admirers, and will survive the winter as comfortably in a vase on a parlour table as under the sheltering sprays of a tolerant Cedar or exposed in the naked top of a Maple or Wild Cherry. They will even submit to an occasional washing, and will come out fresh and glossy-relieved of accumulations of the inevitable dust. These bunches of brilliant colour often relieve the dark-green shades of the Cedar, a tree with which the vine seems to take all manner of liberties. Each berry has a showy, orange rind, that opens in three parts like a half-peeled orange, displaying the bright scarlet fruit. This has three minute ridges formed in its efforts to open the divisions of the rind. When the clustered berries wither on the Night-shade and grow dull on the Mountain Ash with the advance of winter, the bright colours of the Bittersweet seem to grow more and more brilliant. 
Sometimes a vine will clasp a young tree and vigorously strangle it to death, reaching out and up into the tops that rise indifferently above its victim. Elated by its success, it will grow larger than the dead trunk around which it twines in a rapid spiral. Often it takes but an indolent hold of a sturdy tree, as if reluctant to admit its dependence. Occasionally it swings clear of the sustaining trunk, holding only by the branches as much as twenty feet from the ground, and leaving the mystery of its wonderful climbing feat unsolved. A few curves in the pendent vine suggest a victim which has served its purpose and passed away, for a trunk so soft and pliable might loose the coils with which it strangled a supporting tree. Hanging unsupported, it is as light and flexible as a rope, and, when two or three inches in diameter, an irresistible temptation to climb.

The berries have the reputation of being poisonous, and a similar evil fame attaches to the wood, bark, and roots. A European namesake deserves this bad reputation, and our own artistic vine is not free from the taint of suspicion. The inquisitive find the berries mildly sweet and liquid, not at all disagreeable; but a taste is sufficient to satisfy curiosity. In spite of their tempting and conspicuous colours, they are left severely alone by the birds in fall and winter. The inquisitive Grosbeaks often fly leisurely to a tree where the bright tints are attractively displayed, but, 
after looking sagely about, start away after the more satisfactory Thorn Apples or Mountain Ash berries. The Bittersweet manifests a decided preference for the Cedar, which it seldom strangles, but twines about in a helpful way. Perhaps it is because the dark, palm-like sprays of the evergreen afford the finest contrasts for its glowing orange and scarlet. Nowhere does it seem so well to deserve its common name "waxwork" as when drooping between the shelving foliage of a snow-decked Cedar. There it shows that the season of fruition can reveal beauties rivalling the bloom of spring, beauties unmarred by obtrusive utility and free from the persistent and oppressive sense of evanescence. 

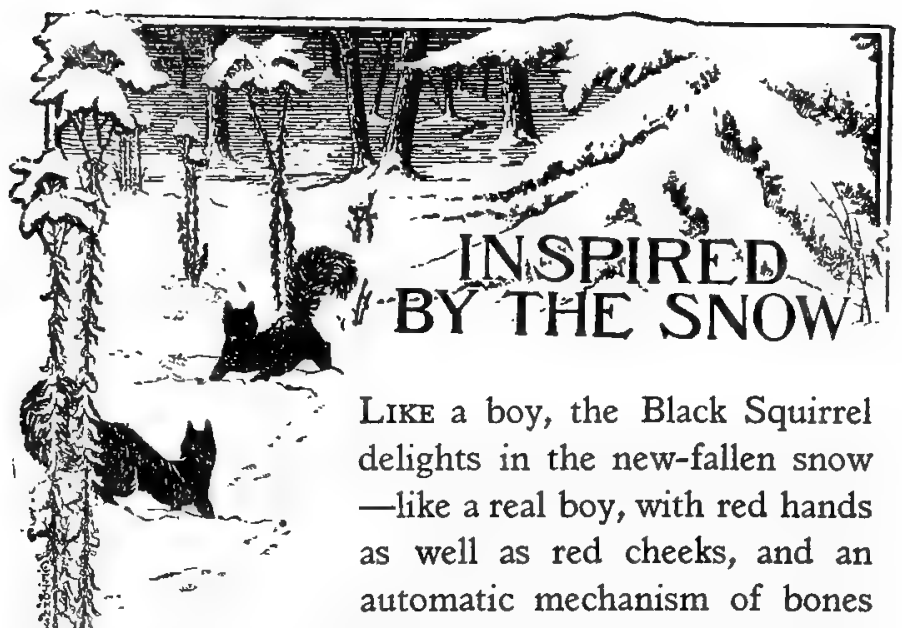

LIKE a boy, the Black Squirrel delights in the new-fallen snow - like a real boy, with red hands as well as red cheeks, and an automatic mechanism of bones

and muscles capable of all things except rest. The first snow sends a thrill of joy through every fibre of such a boy, and a thousand delights crowd into his mind. The gliding, falling coasters on the hills, the passing sleighs with nitches on the runners for his feet, the flying snowballs, the sliding places, the broad, tempting ice, all whirl through his mind in a delightful panorama, and he hurries out to catch the elusive flakes in his outstretched hands and shout aloud in the gladness of his heart.

The Black Squirrel becomes a boy with the first snow. What a pity he cannot shout! There is a superabundant joy and life in his long, graceful bounds, when his beautiful form, in its striking contrast with the white snow, seems magnified to twice its actual size. Perhaps there is vanity as well 
as joy in his lithe, bounding motions among the naked trees, for nature seems to have done her utmost to provide a setting that would best display his graces of form and motion.

When the falling snow clings in light, airy masses on the Spruces and Pines, and festoons the naked tracery and clustering winter buds of the Mapleswhen the still air seems to fix every twig and branch and clinging mass of snow in a solid medium of crystal, the spell of stillness is broken by the silent but joyful leaps of the hurrying Squirrel. How alive he seems, in contrast with the silence of the snow, as his outlines make changing silhouettes on its perfect white! His body curves and elongates with regular undulations as he measures off the snow with twin footprints. Away in the distance he is still visible among the naked trunks, a moving patch of animated blackness. His free regular footprints are all about, showing where he has run hither and thither, with no apparent purpose except to manifest his joy in life.

His red-haired cousin comes to a lofty opening in a hollow tree and looks out with an expression of disappointment on his face. He does not like the snowcovered landscape spread out so artistically before him. It makes him tired, and he has not enough energy to scold an intruder, as he would in the comfortable days of summer. No amount of coaxing or tapping will tempt him from his lofty watch-tower, 
or win more recognition than a silent look of weary discontent. Another cousin, the Chipmunk, no longer displays his daintily-striped coat. Oblivious in his burrow, he is sleeping away the days, and waiting for a more congenial season.

Among the branches of an Elm the black Squirrel is twitching from one rigid attitude to another, electrified by the crisp atmosphere and the inspiration of the snow. Again he is leaping over the white surface to clamber up the repellent bark of a tall hickory. Among the larger limbs he disappears. As he never attempts to hide he must have retired into his own dwelling to partake of the store laid by in the season of plenty. Hickory nuts are his favourite food, and the hard shells seem but an appetising relish. He knows the value of frugality, and gathers them before they are ripe, throwing down the shrivelled and unfilled, that the boys may not annoy him with stones and sticks. In winter he is the happiest of all the woodland family. He does not yield to the drowsy, numbing influence of the cold, nor to the depression of a season of scanty fare, but bounds along from tree to tree, meeting the challenge of the frost king with overflowing joy. 


\section{AN EVENING REVELLER}

IN the close, quiet Cedars of the suburban woods the Screech-owl finds a comfortable home throughout the winter. He is impervious to the vagaries of the weather, for, like most members of the owl family, he does not dissipate in foreign travel or otherwise attempt to elude the changing seasons. All day he perches silently in the deep shade of the Evergreens, closing his eyes against the light that struggles persistently through, poised as a sentinel, with ears erect and seemingly alert to all the passing activities of the winter woods. But that is merely an unconscious pretence, for the little sentinel, no bigger than a Robin, is almost as oblivious to his surroundings as the dull grey limb he so closely resembles. Vagrant Dogs may rush through the snow and sniff at the hidden trails of the Field Mice, and he will scarcely incline his head toward the noisy commotion. The hunted Cotton-tail, leaping over the snow to his burrow, with wild-eyed memory of the Ferrets underground and the Dogs and guns awaiting his escape, passes and leaves his quadruple track unnoticed. Chickadees swing under adjacent twigs and feast on the clinging insects in the crevices of 
the bark, but the strangely human-like eyes of the Screech-owl do not discern them. This silent, sleepy stupidity is his salvation, for he is helpless against the attacks of small birds when blinded by the glare of day. It also saves him from the marauding bipeds who pass with guns and look at him again and again without seeing him.

The Screech-owl makes a strange and interesting departure from the almost universal rule of sameness in species. Almost all other birds adhere strictly to the fashions in style and colouring. Almost every feather has its distinguishing marks and shades, and these are repeated with wonderful fidelity. Males may have distinctive markings and colourings, but males of the same species are almost invariably alike. The same is true of the females and of the young, and when changes occur with the seasons all adhere strictly to the prevailing modes. That accurate sameness in every species would be regarded as wonderful were it not an almost universal rule. But the Screechowl has the rare distinction of being an exception. Grey and brown specimens differ so widely that they would naturally be regarded as distinct species, but they are of the same bone and flesh. Theydo not change with the seasons, for a brown or a grey bird, male or female, retains its colour through life. Young of both colours are found in the same brood. This may represent a formative stage in the development of a 
species, and in the coming centuries the grey Screechowls may separate themselves from their brown brethren, refuse to intermarry, and take on some distinctive forms and characteristics. Although specimens are found of intermediate colouring, the tendency is toward the two distinctive types. It is the accurate sameness, and not the variation in species, that is yet to be explained.

With the closing in of night the Screech-owl shakes off the lethargy of the day and rouses into open-eyed wakefulness. Then the trembling, plaintive call that his friends will linger in the night to hear fills the still, pyramidal Cedars and floats away into the cloudlike branches of the Pines. He starts across the open space, his straight course outlined against the sky, and the vigorous, rapid fluttering of his wings strangely silent. His predatory nature is now awake, and the eyes that blinked in the dazzling sunlight are strained to discern any unfortunate bird or mouse that chances in his vicinity. Again and again his plaintive tremolo fills the woods. There are some who shudder at its weird sadness, and hasten from it to the sustaining companionship of artificial lights. But the long, trembling note is music to the ear of understanding. Its very weirdness brings a satisfaction in the still evening. It is the voice of the forest whispering to the stars. 


\section{THE GREAT HORNED OWL}

THIs is the most human-looking of all the Owls. There is something searching and penetrating in the fixed stare of his great round eyes. The suddenness of encountering him face to face, and the strangely silent flapping of his great brown wings as he darts and dodges away among the trees, seem to impress the mesmeric weirdness of the woods. Such meetings are, indeed, rare, for he shrinks from human intrusion, and will face a score of feathered tormentors to avoid an inquisitive invader of his retreat. His appearance abroad is the signal for a general attack. All the birds in the neighbourhood join the hue and cry. Foes are for the time united. Robins and Blackbirds make common cause. Kingbirds dart at him vindictively, and even the Song Sparrows lend moral support to the attacking force. Driven to a perch, his erect attitude and impressive assumption of dignity do not preserve him from the assaults of his persistent enemies. Again and again they dart at him, as his big, round head turns slowly and ponderously from side to side. Despairing of peace, he once more spreads his wings and hurries away in search of deeper and more sheltering retreats. But the penalty 
for venturing abroad in the sunlight is generally a day of torture, for the commotion is certain to be continued by succeeding forces of assailants till evening settles down and his dazzled eyes resume their strange nocturnal discernment. Then, with ear-like tufts erect, his attitude becomes alert and watchful, and the predatory nature that makes him an object of aversion throughout the woods is once more aroused.

This is one of the largest and strongest of the Owls, and his bad reputation has unjustly tainted the family name. He preys indiscriminately on birds and small animals, and has been known to feast on a diminutive member of his own race. The capacity of his throat is astonishing, for a specimen taken in the vicinity of Toronto was found to have swallowed a half-grown Muskrat. Pigeons and Chickens are frequent victims, but he pounces indiscriminately on all the feathered tribe that roost in the woods at night. Of late years all the birds of the forest have had a fair trial by impartial jurors, and, wherever possible, the benefit of the doubt has been given in their favour. Almost all the Owls and most of the Hawks, formerly outlawed and liable to be killed at sight, have been pronounced friendly and beneficial. They have been found to feed entirely on injurious insects and vermin. But the reputation of the Great Horned Owl has been blackened deeper and deeper with every investigation. Every night his 


\section{THE GREAT HORNED OWL}

savage hunger must be sated, and while he seems to reject nothing that has life, the perching birds are his most frequent victims. Even in winter he grows fat through ceaseless depredations. To see him flying at night across the disk of the full moon, his silent wings sweeping through the naked branches of an Elm, is an event to be remembered-even more rare than a daylight meeting, face to face, in the close shade of a Cedar swamp. His tremulous monotone is the true voice of the woods. Weird it may be, repeated again and again, expressive in its expressionless evenness, and so oppressively spiritless that it seems to breathe a pulsating spirit through the silence that it cannot disturb. 


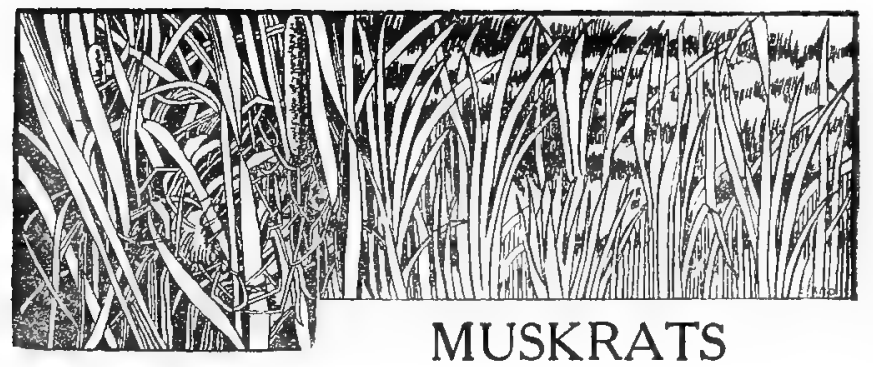

BECAUSE the mild and silently indifferent Muskrat continues to build his house of aquatic vegetation, while club houses, mansions, cottages, grand stands, and electric lights rise up about him, he is classed as an invader. He is, in reality, the rightful heir refusing to be dispossessed. With every approaching fall Muskrats build along the lagoons of the Island and the tortuous reaches of the marsh. Their houses are not shown on the registered plans of the city, although some of them are really imposing structures, appearing at a distance like old and moss-covered stumps spared by the wood-gatherers. These builders treat the advances of civilisation with calm, amphibious indifference, and even when their building sites are turned into wharves and piers they will take up their residence in holes and crannies, degenerating into a condition of semi-domestication. But it will be many years before Muskrats are driven to flats, tenements, and temporary lodgings.

While the Beaver is first to retire before the invasion of man, his little cousin stays until the hunter's cabin 226 


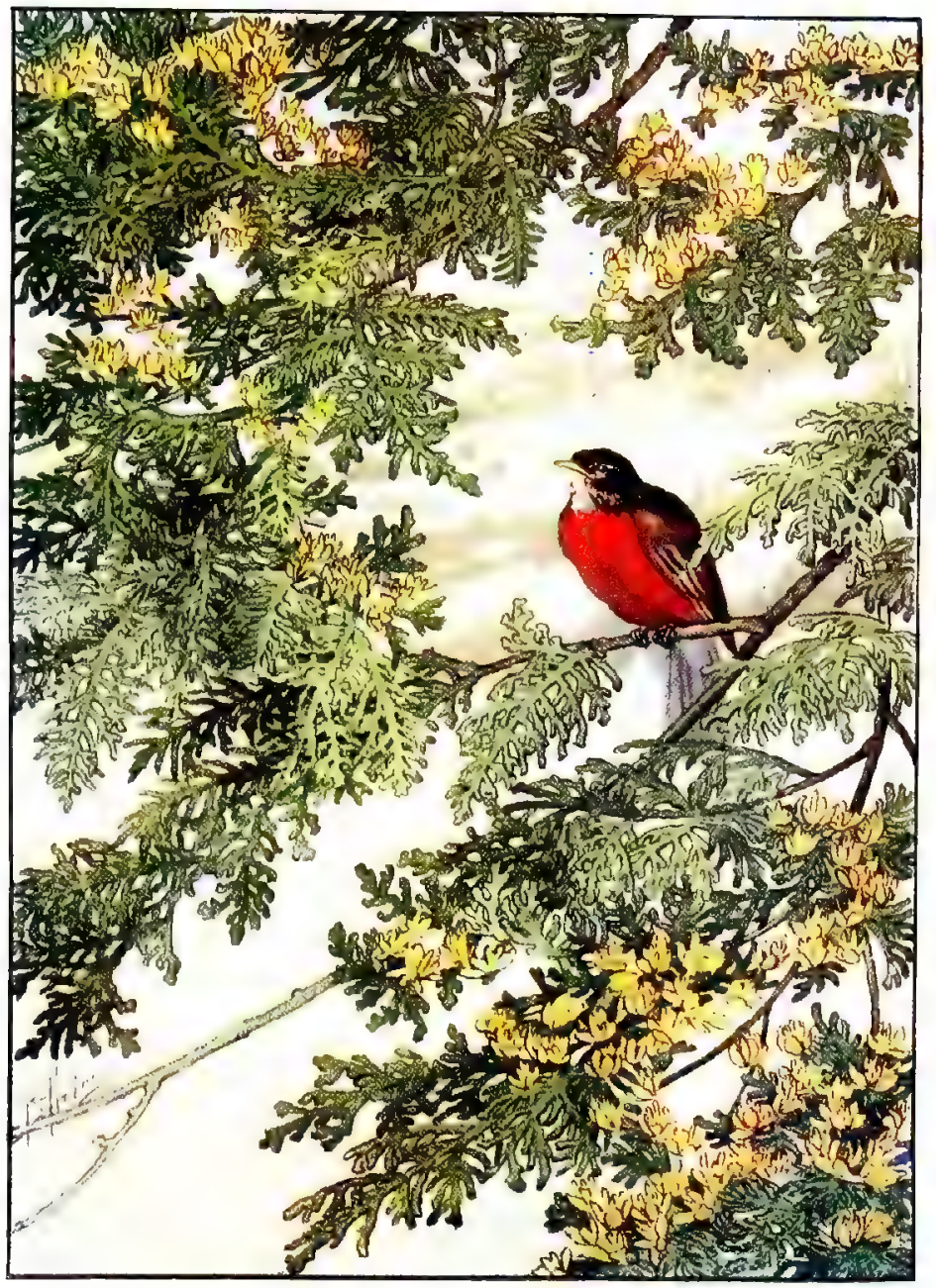

WINTER'S ROBIN 

is succeeded by the pioneer settlement, and on through all the mutations that culminate in the great city. The Beaver is wise. The Muskrat has the happy faculty of accepting every situation and calling it good. When the sand-pump fills his favourite lagoon, and his few human sympathisers have bidden him good-bye, he comes next night and trails his glossy tail over the fresh mound, crossing and recrossing it in a labyrinth of straight and curved lines, and making the new shores old with the countless indentations of his nimble feet. Like ourselves, he becomes nocturnal in his habits as urban growth advances around him. Should he become inured to a civilisation ancient as that of China he may be as indifferent as a laundryman to the rising and setting of the sun in ordering his hours of labour and repose.

The after-dark of early autumn, before the crescent moon has left the sky to the vigils of the stars, is the time to commune with the Muskrats. The excuse for being abroad, whether it be gun, fishing-rod, insect net, or botanising case, must be laid aside, for there is something imperious in the all-pervading hush of evening that will not tolerate an interruption. From the boat pushed well into the rushes the clear, smooth lagoon stretches away toward its margins of impenetrable shadow, so still that the mirrored stars do not even tremble. A black dot comes out of the darkness straight across the silent water, leaving 
behind two long, trailing ripples that steadily widen and recede, shedding gleams of silver where the water had been invisible in the shadows.

On he comes steadily, his head strained rigidly forward and barely above the surface. Now he is so close that his little, beady eyes can be seen in the moonlight. Splash! The round of his back and his snake-like tail appear for a moment above the surface as he disappears, leaving the quivering ripples to seek the black distance in widening and widening circles.

Another appears swimming steadily and smoothly toward the irregular house that has just been erected on the opposite shore. He seems to revel in the stillness and the joy of being alive. On the shore his saturated fur glistens in the moonlight. He mounts the house, quietly enjoying a feeling of proprietorship. A feast of clams has tempted him, for the sound of the cracking shells comes across the lagoon. Mirrored in the water and catching the faint light of the sinking moon, what more ecstatic situation could any creature discover or devise? It makes one long for the fulfilment of the oriental faith in the transmigration of a spirit to taste the joy of the silent moonlight on the glassy surface of the lagoon.

The Muskrat houses are a relief in the frozen desolation of the marshes in winter. Rising from the ice, rough, irregular piles of frozen weeds, catching little drifts of light snow that fill up the open masses 
of dead rushes, they seem at first to emphasise the generally cold, deserted aspect. But look on the sunny side of a house, and the white frost will show the thin spot where the warmth of the little colony has thawed the wall. That is the breathing-place, and the air filtering through leaves soft hoar-frost on the outside. With moccasins it is possible to approach without disturbing the inmates and to hear them moving inside. The sound of life in such a desolate place is ample reward for an hour's patience. The least noise, an incautious step, or even the cracking of the ice will send them scurrying down into their burrows in the frozen mud or through the water under the ice to safer quarters. The interior of the house is a low, ice-lined dome, with a floor of open water leading down into ramified burrows. In a house recently visited near the city the water was crowded with living mud-minnows, and the stains on the icy walls gave suspicious proof that the occupants had indulged in a fish diet. The Muskrat has an accommodating nature and may degenerate into the common life of a Sewer-rat. But so long as he adheres to the trying ideal of living his own life and minding his own business he should have at least an absolute immunity from eviction while the ice is on the marsh. 


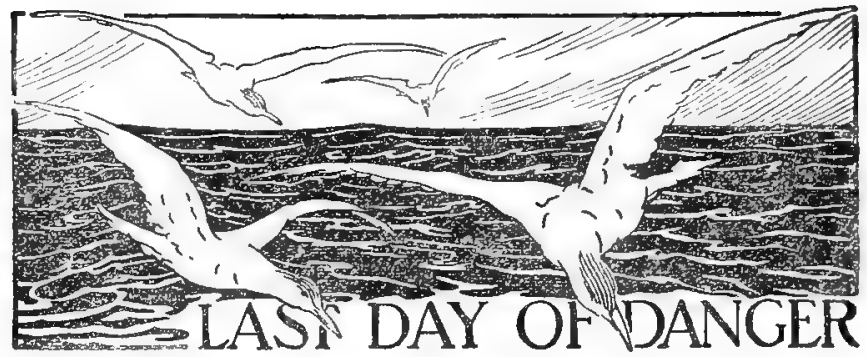

As the harsh, aggressive ice closes in about the open spaces in the bay the food problem grows more and more difficult for lingering flocks. Red-heads, Bluebills, Coween, and a few W/histle-wings flaunt the cold and defy the niggardliness of the frozen north in covering up her few remaining stores of food. There are a few roots and some worms for the more dainty feeders, with here and there a bunch of pond grass rising from the bottom, and the omnivorous Coween find small fish in the open water. Snails lodged in the green vegetation on submerged and decaying timbers are not rejected. Still the food problem presses with greater and greater intensity, and the small flocks hurry back and forth between the ice-girt opening in the bay and the broad, cold, turbulent expanse of the lake. Their swift, quivering wings and steady, lowering course as they seek the dull grey enshrouding distance make a marked contrast to the leisurely soaring Gulls, at home in all places and seasons, pursuing seemingly purposeless courses and settling down wherever the buoyant water carries an acci- 
dental morsel of food. The friendly association of the gulls is quite irregular, and even a flock of many score move along in seeming confusion, some high in the air, others close to the water, and the leaders and stragglers frequently changing positions. The Ducks seem to have a serious purpose in life, and they follow their straight courses in geometrical lines and with regularity of movement.

The last day of the year is the last serious menace of the human enemy, and although the legal truce will be broken many times, open aggression will be at an end. Among the ridges in the ice barriers on the shore a few figures in white are struggling with the problem of keeping warm and keeping still. A bunch of floating decoys are gradually accumulating rings of adhering ice that lessen their deceptive resemblance to a feeding flock. In the restless water the intense cold gradually enlarges these deforming loads, still the wooden forms nodding on the waves are sufficiently deceptive to bring an occasional flock away from their usual course over the open gap. The Ducks have abundant warning in the badly-concealed boat, the ice on the decoys, and the waiting enemies who must move to keep from freezing. But the eager quest for food makes every prospect attractive. Whenever a hungry flock curves within the uncertain range every barrel is discharged. The flashes and sharp detonations of the smokeless powder warn 
them off, and they lower away steadily into the concealing horizon. The new year will bring a cessation of hostilities, and the lingering flocks will have no open enemies, except the increasing cold and the ice that shuts them from their submerged stores. 


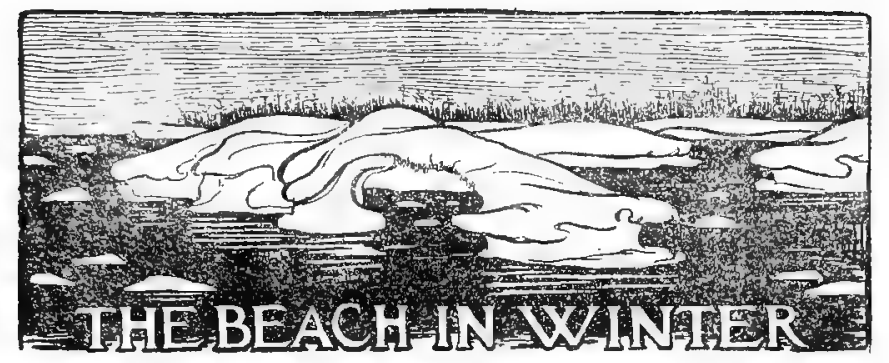

THERE is a fascination in the rage of the elements: the wild roar of the winds, varying with savage persistence; the hoarse churning of broken ice against white, stolid barriers on the shore, and the high, tumultuous waves, with torn wreaths of foam, coming out of the opacity of the driving snow and spending their massive strength under the long, undulating stretches of imprisoned ice. The expected roar of the driving waves on the shallow slopes of yielding sand is hushed under the long, slow rise and fall of this crowded, floating load that seems a strategic defence for the fantastic and solid ice barriers that line the shore. Against the near horizon, blurred by the flying needles of snow, wave after wave rises in magnificent strength, shaking its mane of foam loose to the impatient storm, and rushing with mastering violence on the long defences. But out at the margin the floating ice rises high to meet every attack, and the force is slowly spent in a long, diminishing undulation reaching toward the shallows, 
where rough fragments churn and grind in the yielding sand. Though the spontaneous voice of the breaking waves is hushed under the load of broken ice, the loud tones of the wind are all the more insistent and penetrating as they vary through the Willows and Poplars or angrily resent the artificial obstructions that men have presumed to erect. The sand is mingled with the sharp needles of snow that load the flying air, and it whisks across toward the protected water in sudden clouds or piles up solidly in long, irregular ridges.

There are many beautiful accidents in the patterns traced by the wind in the sand, and the figures seem strangely complacent in the bewildering hurry of wind, waves, and cutting sleet. Some of the Scrub Willows are almost buried under the drifts, and others are so robbed of their supporting banks that bunched roots are hanging from them like unhealthy or parasitic growths. But the Willow is an accommodating tree or shrub, and any part buried will send roots into the earth, while any part exposed will spread leaves to the sun. Even if inverted it will accept the situation. Out on the lighthouse piers, where there is no protecting floats of ice, the waves break in unabated fury, festooning the life-line and all the framework with icicles, and surging over the cribwork from the confining reach of the gap. After two or three vain attempts a determined wave rises higher 
than its fellows and rushes across the spiked timbers, threatening all obstructions with its weapons of loose ice. Such a spectacle imitated painfully and incompletely in tinsel would draw crowds of spectators. But the lighthouse pier, the grand theatre of the storm, where the only penalty is the bruises of the icicled life-line and the wet of the breaking and encircling waves, is alone and deserted. The stormloving Gulls call in shrill exhilaration, poising almost motionless, defiantly breasting the pressure or steadily rising to turn and curve swiftly downward with the aerial current. One sign of life is ridiculous in its insignificance. A Rat comes out from the snow banked about a willow beside the dock, but in surprise at seeing a traditional enemy abroad, returns quickly to his shelter, leaving the imprint of his brief excursion in the packed drift. While the elements rage and the force of the storm is spent on the resisting shore this little atom of life is making its way and doing its part in the incomprehensible scheme of a universe of wonders. 


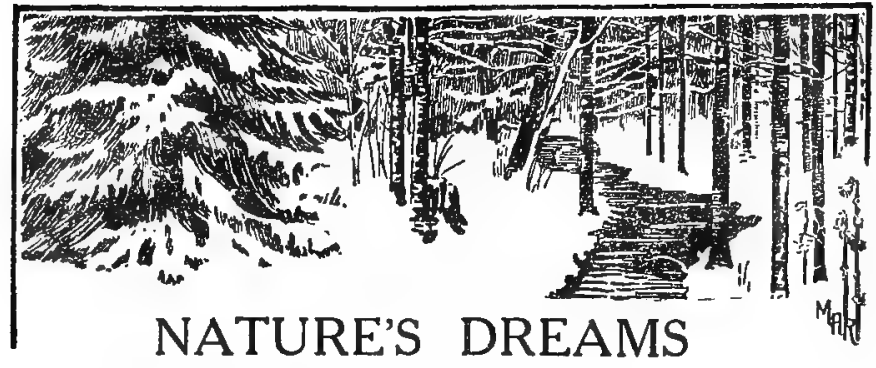

NATURE has drawn her white coverlet and tucked it carefully in around about her, calmly composed for a sound, tranquil sleep. This is the casual and quieting impression from an easy position above the stream now showing as a smooth, winding hollow in the unbroken whiteness of the field. A few Willows and Alders almost buried on the opposite bank seem like splashes of ink on a clean page, and away toward the rising hill that leads to the dense, dark green of the Spruces a black patch of hurrying water shows that under the ice and snow the stream is still alive. Is it the only evidence of life? In front the snow is unbroken in every direction, while behind. the winding row of deep indentations tells how the wayfarer may pursue a tortuous course while fondly imagining his path straight. Immediately in front, waiting to be obliterated with the next random step, is a small hole in the snow as round and clear-cut as if made by a walking cane. No pedestrian has been near since the unbroken sheet of snow was spread so 236 
carefully over field and stream. Could a weird nightly visitor have careened on a broom over the distant pines and across the field in the moonlight, pausing to rest on the smooth rounding bank A running stream is an impassable barrier, and there the witch may have paused to breathe out maledictions at the fate that balked her evil designs. A short distance away there is another hole in the smooth snow, and now that the eye has begun an unconscious search several more are discovered. Did the moon look down on an unhallowed orgy of the terrible sisterhood, arrested in their fell purpose by the mystic power of the moving water under the snow? There is the mark of their trailing garments. But the lines are drawn in concentric circles with mathematical accuracy, showing, perhaps, a cabalistic warning to the unfortunate wayfarer who might wander, however innocently, over snow made baneful by their machinations and the exhaled wickedness of their sacrilegious rites. A mind in intellectual twilight, filled with the strange fears that linger like mists on the dawn of supernatural thought, could find in the snow-covered field the premonitions of evil and the signs of a vague and terrifying life, peopling earth and air with its fantastic and distorted forms. Stimulated by fear, it must have been easy and natural to account for every trifling circumstance of unusual aspect or momentary mystery by fancying the sur- 
rounding universe alive with human activities. Did the witches riding on their brooms alight for a moment in their wild orgy?

All mysteries yield to investigation. Under the surface these round holes become intricate and winding burrows, where the Field Mice have been enjoying the bracing climate. Every part of the field has been crossed and recrossed by them. Their winding course is seen wherever the snow is kicked away. This explains the phenomenal activity of a Dog that has covered the hillside close to the woods with tracks, while no trace of his quarry appears on the snow. He has been running the scent of intricate winding trails underneath.

Over by the edge of the stream, where the snowcovered ice reaches out on the black water, one of the little burrowers has made his way to the surface. It is probably a Shore Mouse, and his little tracks look helplessly diminutive on the great waste of snow. The wind toying with some broken Golden-rod stalks. has described accurate circles in the snow before twisting them off and whisking them away. It has cleared the snow from a low Sassafras thicket, showing where the destructive little excavators have girdled the bark, leaving the young trees to die in the spring.

Up the stream, where even the running water seems a part of the dead landscape, a Muskrat comes 
out from the margin of snow-covered ice, rises above the surface more black than the black water, swims directly across and sinks under the ice at the other side. At once it is apparent that not only the white mantle of snow, but the solid banks, are alive with animal activity. Below the easy tunnelling of the Mice in the snow the Muskrats are burrowing about in the ground.

What life abounds where all things seemed so dead! Nature is but dreaming. Kick away the light crisp covering, and the waxy green leaves of the Wintergreen, with its bright red berries, are found as fresh and tempting as in early spring. The frozen earth, under the snow, is congenial to this healthy emblem of winter. A bunch of Hepatica leaves is found, green and vigorous, and the Trailing Arbutus is growing and budding in anticipation of the season of awakening. The Ground Ivy, even when cased in ice, seems as vigorous and aggressive as under the June sun. Who would have expected to find so many friends of spring and summer at home at this inhospitable season? Around the dead and withered stalk of an Aster the root leaves are preparing for spring. The Golden-rod is also putting forth its leaves, and the Pipsissewa shows the hardy vigour of summer. The covering of snow merely conceals nature's activities. The Gold Thread, the Partridge Berry, and the Twin Flower are easily discovered in their 
familiar haunts among the now disconsolate and naked trees.

A hesitating, discontented, but familiar chirp comes from a closely-crowded bunch of Cedars half way up the hillside. But a long and patient wait does not induce the friend of summer to reveal himself. The Cedars must be slowly and steadily circled so as not to disturb him. An opening appears above a low-spreading branch, and there, with bunched and huddled form outlined against the background of snow, sits a solitary Robin who has preferred the cold of the dense Evergreens to the gay surroundings of the hospitable south. He will be of the first to greet the returning spring. Both in sombre colour and quiet demeanour he contrasts with the lively, energetic, and sometimes noisy Blue Jay that has flown out of the deeper woods. This gay disturber is pulling energetically at a belated acorn that has remained, like the bunches of last year's leaves, on a lofty branch of the white Oak. Although distressingly industrious, and even vain of it, the Jay is easily forgiven. When he stays through the winter he makes the best of the situation and takes the white world as he finds it, never sulking, grumbling, nor assuming an air of dejection. He never huddles together in his feathers to wait for summer, but lives his life day by day, taking all the joy there is and shedding it about, indifferent to all seasons. He is the mischievous child 
of the woods. And who can resist a mischievous child?

A cry, harsher than the most diabolical note of the Blue Jay, comes from a group of naked Silver Birches. It must be a conveniently cold winter that has enabled the blue disturber's rare cousin, the Canada Jay, to travel so far south. The bleak plain and naked trees must seem almost sultry to him as he moves rapidly but solemnly about. The Canada Jays are more serious than their gay-coloured relatives, and they build their nests and rear their young with the thermometer many degrees on the wrong side of zero, just to teach the world contempt for the weather. While watching the antics of the Canada Jay a half score of purple Grosbeaks settle in the Hemlock directly overhead and begin to pull the cones to pieces. In their arctic home they have learned nothing of human destructiveness, so a man is not an object of fear or aversion. They come to the lower limbs and look curiously into his eyes, but seem to regard him as a rather unprofitable proposition. Nature is ever wise. Their confidence, even if born of indifference, is refreshing in a world of doubt. The Crows, wiser in their own generation, have a sentinel outlined against the sky on the tall spiked trunk of a dead pine, while they gather with their friends and neighbours at a sumptuous feast in the depth of the ravine. 
The mystery of unceasing life and growth is all about, as persistent on the bleak plain and in the naked woods of winter as in the season of crowding foliage and many-tinted flowers. As if to more loudly proclaim the all-pervading activity of winter, there is a distressing commotion among the Chickadees and Juncoes in the near Hemlocks. The Kinglets, too, in the naked top of an Elm, are suddenly alarmed. They cannot fear the Black Squirrel bounding over the snow to shelter among the Spruces. The Hawk circling away overhead does not account for their trepidation. There is the enemy, a skulking but determined and wicked-eyed Shrike, conspicuous in black and white, flapping his course under the lower branches and looking for his prey among the hardy feathered inhabitants of the winter woods. With perpetual life and growth comes its inseparable complement, perpetual destruction. 


\section{INDEX}

Alders, 3, 15, 26, 102

American goldfinch (or wild canary or thistle bird), I73175

American mergansers, 28-30

Anosia plexippus (monarch butterfly), 145-I48

Arethusa, 76

Arrowhead, 49

Arvicola riparius (shore mouse), $5,25-27,238$

Aster, 12, 22, 25, 74, 132, I55, 159, 239

Balm-of-Gilead, II4

Barn swallow, 32

Basswood, 56, II 13

Bat, 51

Beavers, 25, 70, 226, 227

Beech drops, 190

Beech nuts, 189

Beeches, I88, 2II, 212

Bellwort, 59

Birches, 4, 63, I14, 159

Birds and struggle for existence, 172-173

Bittern, 50, 124

Bittersweet, 2I4-2I 6

Black birch, 4

Blackbird, 3, 31, 50, 128, 130132, 182, 223

Black cherry, 52

Black-heart, 98

Black squirrel, 2I7-a19, 242

Błack warbler, 102

Blood-root, 37, 38, 42, 44, 59, 71, 75

Blue-bill, 189, 230

Bluebird, 3, I1, 12, 13, 18, 3r, 57,199

Blue heron, 50

Blue jay, 240

Bobolink, 172

Boneset, 170

Brown creeper, 31,36

Brown thrasher, 57, 81, 103, 128

Bulbed fern, III

Bulrushes, 123-125

Bush honeysuckle, 72

Calopogon, 170

Canada goose, 39-4I

Canada j2y, 24I

Cancer root, 190

Cardinal lobelia, 74, 153

Carolina rail, 124

Catbird (or Canadian mockingbird), 103, 128, 139-141

Caterpillars, 52

Cedar, 21, 102, I10, 188, I99

Chebec, 96

Chickadee, 63, 113, 196, 204, $205,220,242$

Chickory, 72

Chipmunk, 50, 219

Chipping sparrow (chippie), 82, I05-108

Choke-cherry, 92, 189

Clams, 78

Closed gentian, 49

Cone flower, 74

Coot, 182-184

Cornucopia, 155

Corpse plant, 190

Cottontail, 5, 220

Cowbird, 105-108, 130 
Coween, 230

Crossbills, II 3

Crow, 5, 21, 88, 89, 95, 102, I28, I8I, 24I

Dandelion, 25, 59-6x

Deer, II 4

Divining rod, $\mathrm{I}_{3}$

Dodder, 48

Dogbane, 72

Dog-tooth violet, 43, 44, 7I

Dogwood, 36, 70, 72

Downy convolvulus, 72

Downy woodpecker, 5, 2I, 3I, 204

Ducks, 28, 23 I

Eel fly, 67, 96

Elm, I5, 35, 56, 70, I10, 159

Epipactis viridiflora, I69-I7I

Evening grosbeaks, I9

Evening primrose, 25, 157, 201

Field mouse, 23, 25, 238

Firefly, 5o

Fire, fascination of, 136,194

Flicker, 3I, 50, 8I

Flycatcher, 32, 94, 96

Fossil remains, 77-79

Fox-glove, I59

Fox sparrow, 3

Fringed gentian, 74

Fringed orchis, 75

Frog, 50

Gallinule, 50, 123, 182

Gentians, 49, 72, 74

Golden-crowned kinglets, I80, 205, 206

Golden-rod, 25, 48, 72, 74, III, I32, I55, I59, I70, 239

Goldiana, I I I

Gold thread, 239

Grass, 59

Great blue heron, 149-I5I

Great crested fly-catcher, 96
Great horned owl, 223-225

Great northern diver (or loon), I I2, I I6-I I9, I 76

Great willow herb, 72

Grebe, II7, I83

Grosbeaks, 19, I13, 196, 209, 215,241

Ground cherry, 189

Ground ivy, 239

Gulls, 28, 29, 181, 230, 235

Harebell, 75

Hawk, I86, 206, 224, 242

Hawthorn, I2

Hemlock, I02, I92, I99

Hepatica, 5, 23, 42, 43, 52, 7I, 75 , III 239

Herb-Robert, II I

Hermit-thrush, 52, II4

Herons, 28, I43, I 49-I 5 I

Herring gulls, I8I

Hickory, 53

High Park, I 70

Horned lark, I2, I3, I8

Horse-chestnut, 56,166

Huckleberry, 53

Hudson River rock, 77

Humming birds, 128, 206

Hylas, 46

Indigo bunting, 82 , III

Insectivorous birds, 126-129

Jays, II, I9, 88, 89, I03, I8I, $200,240,24 I$

Jewel-weed, I55

Jo pie weed, 74

Juncoes, 22, 31, 63, 242

Kildeer, 18,98

Kingbird, 52, 94, 95, 96, 177, 223

Kinglets, 3I, 36, I80, 205, 206, 242

Lady's slippers, 8, 76, 103

Lady's tresses, $8,155,170$ 
Leopard frog, 46

Lilac, 90, 9I, 92

Lobelia, 74, 153, 155

Loon (or great northern diver), II2, II6-II9, I76

Loose-strife, 72

Lordly crow, 5

Maiden-hair fern, III

Mandrake, 189

Maple, 4, 2I, 52, 70, IIO, 159, $188,198,212,213$

Marsh marigold, 49

Marsh wren, 124

Maryland yellow-throat, I02

Meadow lark, 3I, 57

Medicinal herbs, I6I

Migratory birds, 19, 179-18I

Milkweed, 147

Mink, 50

Monarch butterfly (Anosia plexippus), $145-148$

Moon, I85-187

Mosquito, 67

Moth, life of a, 90-93

Mourning dove, 87-89

Mud hens (coot and Florida gallinule), 182

Mullen, I2

Muskrat, 5, 49, 70, 87, II4, I94, $195,226-229,238$

Myrtle warblers, I80

Niagara, 34, I09-III

Night-hawk, 65-69, 92, 100, II6, 127,177

Northern Calypso, 75, 170

Nuthatch, 22, 3I, 35, I27, I9I, 205

Oak, 12, 22, 53, 56, 70, I10, 198 Olive-sided fly-catcher, 96

Ontario, I62, 163

Orchids, I69-I7I

Oriole, 50

Osage orange, 78

Oven-bird, 53, 81, r93
Owl, II, 19, 5I, II2, 116, I76, 220-222, 223-225

Ox-eye daisy, 74

Painted cup, 153

Painted trillium, II I

Partridge, 128

Partridge-berry, I52, 239

Pea gall, 192

Peat fuel, 8

Pellaea, III

Phobe, 96, I27

Pike, 137

Pines, I IO, II4, 188

Pink lady's slipper, 8,76

Pipsissewa, 22, 239

Pitcher plant, 8-10, 153

Plover, I9, I82, 209

Polly-wogs, 47

Porcupine, II4

Potato beetle, 128

Powder post beetle, I20-I22

Prairie chicken, I28

Promethea moth, 90-93

Purple finch, 18

Purple grosbeak, 19, 24I

Purple martin (or black swallow), I35

Pyrola, 8

Quail, I28

Rails, 50, 100, 124, 125

Red fox, 50

Red-heads, 230

Redpolls, 208

Red-shouldered hawk, 206

Red-start, 50, 53

Redwing, 124, 125

Red-winged blackbirds, 3

Ring-necks, I43

Robin, 3, II, I2, I7, I8, I9, 21, $3 r, 34,56,62-64,80,94,127$, I28, I8I, 223, 240

Rock rose, 72

Ruby-throated humming-bird, 128 
Sandpipers, 98-100, 143, 182

Sap-sucker, 34, 35

Sarcophaga, 9

Sassafras, 4, 5, 26, 114

Saxifrage, 202

Scarlet tanager, 172,173

Scented water lily, 49, I53, 154

Scented white violet, 44

Screech owl, 51, II6, 176, 220222

Sedges, 201

Shepherd's purse, 202

Shore mouse (Arvicola riparius), 5, 25-27, 238

Showy lady's slipper, 76, I03

Showy orchis, 75, 170

Shrike, II, 242

Silver birch, 23, 24, 102, 199, 212, 213

Silver maple, 56

Skunk, 50, 70

Skunk cabbage, 5, 6, 7, 43, 52

Snake's mouth, 76,170

Snipe, 127

Snowbird, II, 63, Ir3, 208, 209

Snowy owl, I9

Soft maple, 14, 15, 35, 56, 212

Song sparrow, 3, 2I, 22, 3I, 52, $84-86,103,126,223$

Sora rail, 100, 124, 125

Sparrow, 15, 31, 57, 66, 108, 127, 128, I74

Sparrow-hawk, 128

Sphagnum, 8, IOI-IO4

Spotted sandpiper, 98-ro0

Spring, 17-20

Spring-beauty, 43, 71, 75

Spruces, 21, 102, I99

Squirrels, 50, 88, 89, II4, I89, 217-219, 242

Squirrel-corn, 7I

Stints, 98

Sumach, 26, 179, I88

Sundew, 8, 103

Swallows, 31-33, 66, 127, 133$135,181,182$
Swift, 66, 134, 181

Sycamore maple, 55

Tamaracks, 8, 101

Thistle bird (or American goldfinch or wild canary), I73I75

Thrush, 21, 52, 57, 114

Toad, 45, 46; Shakespeare on, “ 46

Trailing arbutus, 4, 23, 43, 52, 75,239

Tree swallow, 32

Trillium, 43, 75, III

Turtle-head, 156, 157

Tussock moth, 165-168

Twin-flower, 152, 239

Waders, I9

Walking fern, I Io

Warblers, 102, 180

Water arum, 49

Watercress, 5

Water-lily, 49, 153

Weasel, 50, 193

Weather prophets, 195-197

Whip-poor-Will, 87, I16, I28, $176-178$

Whistle-wing, 189, 230

White pine, 56

White throat, 179, 191, 200

White warbler, I02

Wild canary (or American goldfinch or thistle bird), 173-175

Wild duck, 28

Wild geese, I33

Wild orange lily, 72

Wild pigeon, 89

Wild plum, 189

Wild raspberry, 26

Willow, 3, 16, 35, 234

Wintergreen, 4, 22, 201, 239

Witch-hazel, 54, 70, 92, 102, I6I-I64

Wolverine, II2 
Woodchuck, 50, 87

Woodcock, 127

Woodpecker, II, 18, 24, 35, 57, 127, 205

Wood pewee, 35,96

Veery, 53, 81, 103

Vesper sparrow, 3 I

Violets, 43, 44, $7 \mathrm{I}$
Viper's bugloss, 202

Virginia creeper, 188

Yellow lady's slipper (or yellow moccasin flower), 76, 170

Yellow legs, 144

Yellow lily, 49

Yellow warbler, 57, 81, 94, 126, 175 




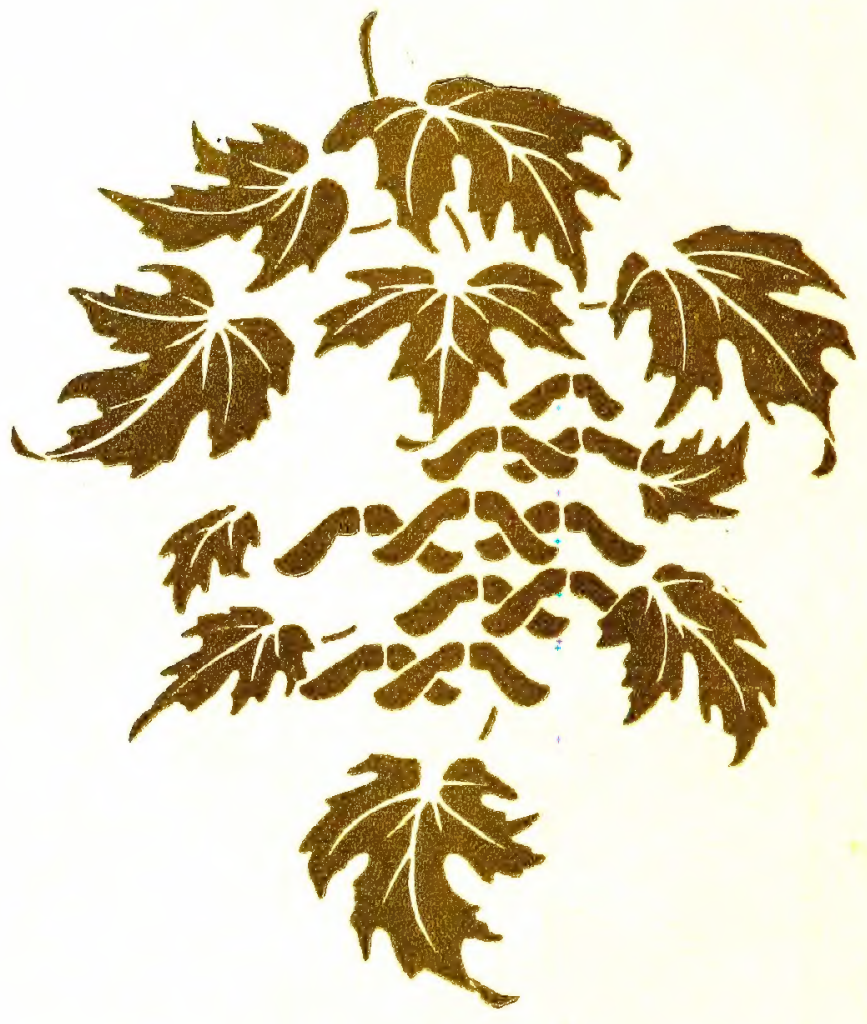




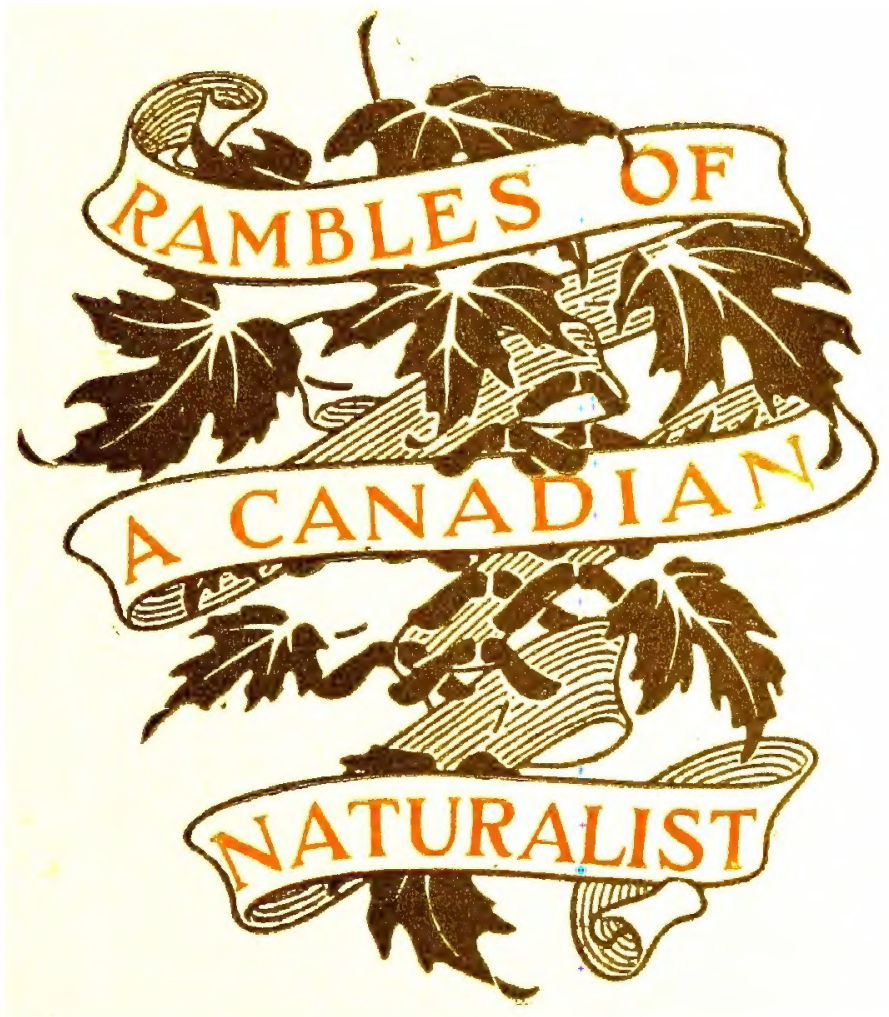




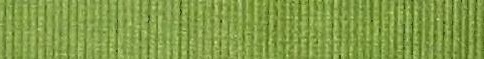

